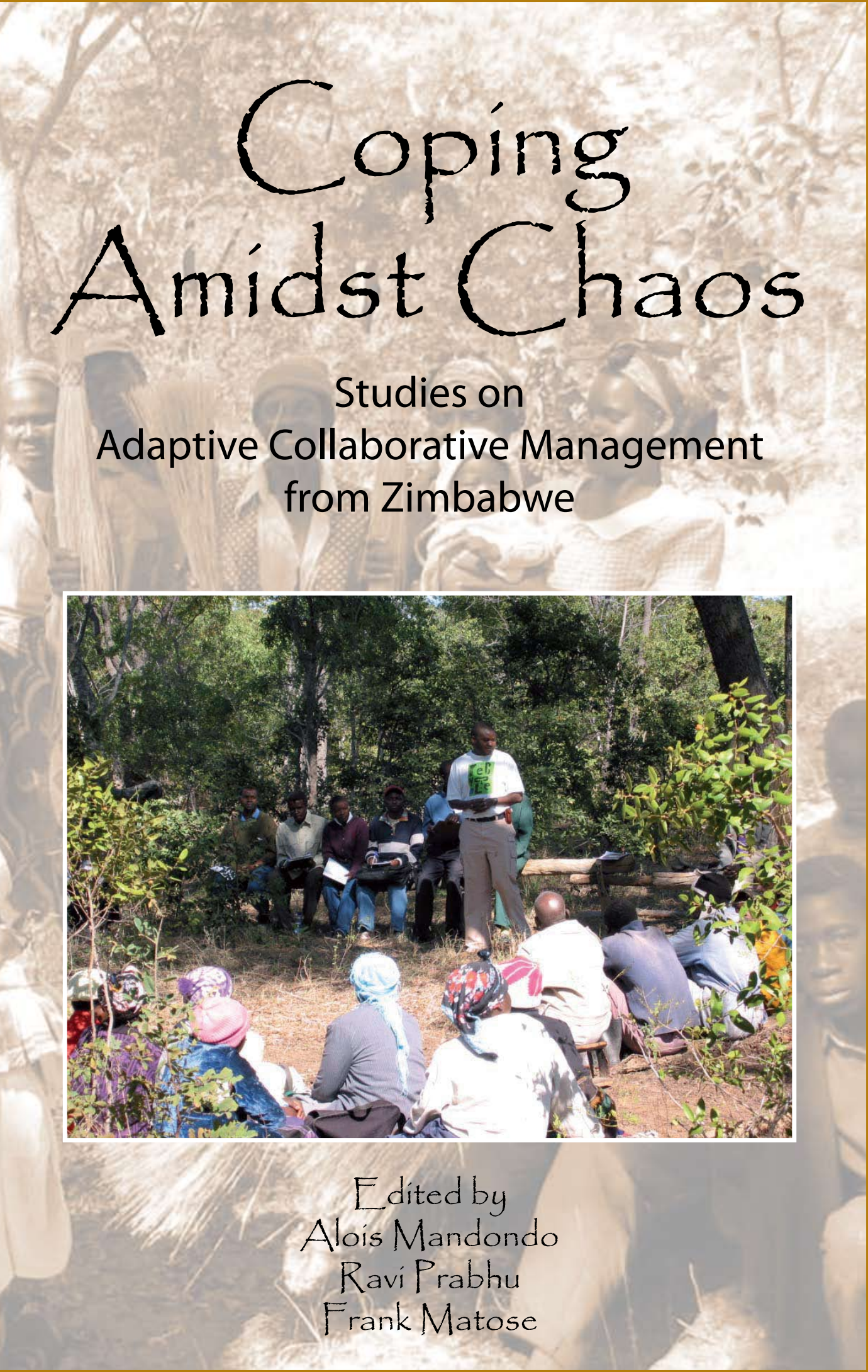





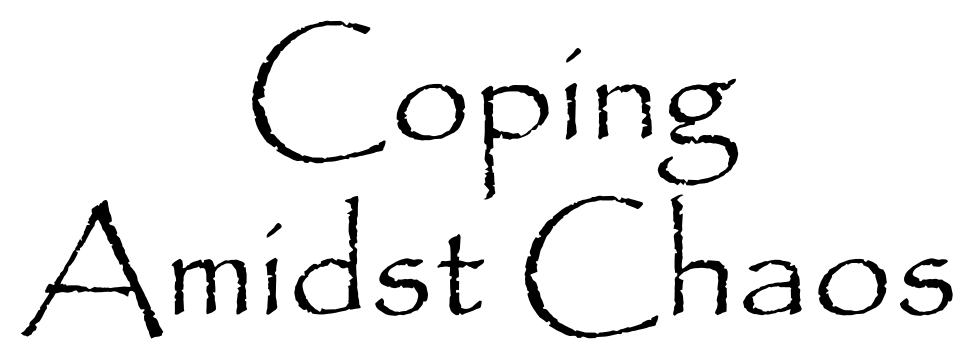

Studies on

Adaptive Collaborative Management from Zimbabwe

\author{
Edited by \\ Alois Mandondo \\ Ravi Prabhu \\ Frank Matose
}


Researched by the Center for International Forestry Research

Jl. CIFOR, Situ Gede,

Bogor Barat 16115, Indonesia

Tel.: +62 (251) 8622-622; Fax: +62 (251) 8622-100

E-mail: cifor@cgiar.org

Web site: http://www.cifor.cgiar.org

Design and layout by Eko Prianto, Gideon Suharyanto and Catur Wahyu

Cover photos by Ravi Prabhu

Alois Mandondo, Ravi Prabhu and Frank Matose

Coping Amidst Chaos: Studies on Adaptive Collaborative Management from Zimbabwe/by Alois Mandondo, Ravi Prabhu and Frank Matose. Bogor, Indonesia: Center for International Forestry Research (CIFOR), 2008.

$132 \mathrm{p}$.

ISBN 978-979-14-1264-3

CABI thesaurus: Adaptive Management, Rural Development, Natural Resources Management, Poverty Alleviation, Action Research, Participatory Rural Appraisal, Community involvement 


\section{ACM Series}

The ACM Series, co-edited by Carol J. Pierce Colfer and Ravi Prabhu, is an informal series of books and manuals published by the Center for International Forestry Research, Resources for the Future and Earthscan. The books listed below, though not a complete list of the group's products, have come out of global research conducted by CIFOR and its partners on adaptive collaborative management of forests.

\section{Books}

Colfer, Carol J. Pierce (ed.) 2005. The Equitable Forest: Diversity, Community and Natural Resources. Resources for the Future Press/CIFOR, Washington, D.C.

Colfer, Carol J. Pierce 2005. The Complex Forest: Communities, Uncertainty, and Adaptive Collaborative Management. Resources for the Future Press/ CIFOR, Washington, D.C.

Diaw, M. Chimère, Tony Aseh, and Ravi Prabhu (eds.) forthcoming. In Search of Common Ground: Adaptive Collaborative Management of Forests in Cameroon. Center for International Forestry Research, Bogor, Indonesia.

Fisher, Robert, Ravi Prabhu and Cynthia McDougall (eds.) 2007. Adaptive Collaborative Management of Community Forests in Asia: Experiences from Nepal, Indonesia and the Philippines, Center for International Forestry Research, Bogor, Indonesia.

Guijt, Irene (ed.) 2007. Negotiated Learning: Collaborative Monitoring in Forest Resource Management. Resource for the Future Press/CIFOR, Washington, D.C.

Hartanto, Herlina, Ma. Cristina Lorenzo, Cecil Valmores, Lani Arda-Minas, Erlinda M. Burton and Ravi Prabhu 2003. Learning Together: Responding to Change and Complexity to Improve Community Forests in the Philippines. Center for International Forestry Research, Bogor, Indonesia.

Kusumanto, Trikurnianti, Linda Yuliani, Phil Macoun, Yayan Indriatmoko, and Hasantoha Adnan 2005. Learning to Adapt: Managing Forests Together in Indonesia. Center for International Forestry Research, Bogor, Indonesia. 
Mandondo, Alois, Ravi Prabhu, and Frank Matose (eds.) 2008. Coping Amidst Chaos: Studies on Adaptive Co-Management in Zimbabwe. Center for International Forestry Research, Bogor, Indonesia.

McDougall, Cynthia, Hemant Ojha, Mani Ram Banjade, Bishnu Hari Pandit, Tara Bhattarai, Manik Maharjan, and Sushila Rana forthcoming. Forests of Learning: Experiences from Research on an Adaptive Collaborative Approach to Community Forestry in Nepal. Center for International Forestry Research, Bogor, Indonesia.

Moira M. Moeliono, Eva Wollenberg and Godwin Limberg (eds.) forthcoming. The Decentralization of Forest Governance: Politics, Economics and the Fight for Control of Forests in Indonesian Borneo. Earthscan/CIFOR, London.

Ruitenbeek, H. Jack and Cynthia Cartier 2001. The Invisible Wand: Adaptive Co-management as an Emergent Strategy in Complex Bio-economic Systems. CIFOR Occasional Paper No. 34. Center for International Forestry Research, Bogor, Indonesia.

Vanclay, Jerry, Ravi Prabhu, and Fergus Sinclair 2006 Realizing Community Futures. Earthscan, London.

Yasmi, Yurdi 2007. Institutionalization of Conflict Capability in the Management of Natural Resources: Theoretical Perspectives and Empirical Experience in Indonesia. Wageningen University, Wageningen, the Netherlands.

Yuliani, Linda, Djuhendi Tadjudin, Yayan Indriatmoko, Dani Wahyu Munggoro, Farid Gaban, Firkan Maulana, and Hasantoha Adnan (eds.) 2007. Multistakeholder Forestry: Steps to Change. Center for International Forestry Research, Bogor, Indonesia.

\section{Manuals}

Cahyat, Ade, Christian Gönner, and Michaela Haug 2007. Assessing Household Poverty and Wellbeing: A Manual with Examples from Kutai Barat, Indonesia. Center for International Forestry Research, Bogor, Indonesia.

CIFOR 2007. Towards Wellbeing in Forest Communities: A Sourcebook for Local Government. Center for International Forestry Research, Bogor, Indonesia.

Colfer, Carol J. Pierce 2007. Simple Rules for Catalyzing Collective Action in Natural Resource Management Contexts. Center for International Forestry Research, Bogor, Indonesia.

Evans, Kristen, and Manuel R. Guariguata 2008. Participatory Monitoring in Tropical Forest Management: A Review of Tools, Concepts and Lessons Learned. Center for International Forestry Research, Bogor, Indonesia.

Wollenberg, Eva, Jon Anderson, and Citlalli Lopez 2005. Though all Things differ: Pluralism as a Basis for Cooperation in Forests. Center for International Forestry Research, Bogor, Indonesia. 


\section{Contents}

About the Contributors

vii

Acknowledgements

ix

Foreword

xii

\section{Chapter One}

Adversity and the adaptive possibility of local communities:

Setting the scene

Ravi Prabhu and Frank Matose

\section{Chapter Two}

Facilitating adaptive collaborative management in forested landscapes: The Mafungautsi case study

Tendayi Mutimukuru-Maravanyika, Ravi Prabhu,

Frank Matose, Richard Nyirenda, Witness Kozanayi

Chapter Three

Action planning and adaptive management of natural resources in semiarid environments: Experiences from

Chivi District, Zimbabwe

Nontokozo Nemarundwe and Manyewu Mutamba 


\section{Chapter Four}

A weighted decision and tenurial niche approach to analyzing adaptive learning in the social forests of northeastern Zimbabwe

Catherine Chahweta and Alois Mandondo

Chapter Five

A comparative analysis of adaptive natural resources management in Zimbabwe

Alois Mandondo and Frank Matose 


\section{About the Contributors}

Catherine Chahweta is an expert on gender, communications and community participation in collective action. Her focus is on rural development where she has worked for over five years with disadvantaged rural communities for nongovernmental organisations.

Witness Kozanayi has an agricultural background and has over ten years experience in facilitating action research in rural settings in Southern Africa. His research interests include local level adaptive resource management and power dynamics among local actors.

Alois Mandondo is a social ecologist with close to 20 years experience in interdisciplinary approaches to natural resource management.

Frank Matose is a sociologist with 20 years experience of working on issues related to society and natural resource management. Research on understanding the contribution of people-centred approaches to conservation, natural resource management and development for policy makers, managers and communities has been a special emphasis. His experience is largely in the Southern Africa region.

Manyewu Mutamba is a researcher at the University of Fort Hare and has a background in economics. He has more than 10 years regional and 
international experience in multi-disciplinary research on rural livelihoods and poverty analysis, environment-poverty links, community-based natural resource management and market analysis, among others.

Tendayi Mutimukuru-Maravanyika is a social scientist with close to ten years experience in community-based natural resource management in Zimbabwe. Her research focuses on understanding the contribution of participatory approaches to both the conservation of natural resources and human wellbeing.

Nontokozo Nemarundwe is a sociologist with sixteen years experience in community-based natural resource management in Southern Africa. Her research has focused on participatory resource management and gender issues in Southern Africa, and adaptive collaborative management of forests in Zimbabwe.

Richard Nyirenda was a member of CIFOR's ACM Zimbabwe team. He is a forester and social development practitioner who worked for almost 10 years in Zimbabwe in both research and development. His work focused on community-based forest management and the development of innovative tools and approaches to improve local people's involvement in resource management.

Ravi Prabhu has engaged in multi-disciplinary research in forested landscapes around the globe for almost 20 years. For the last ten years, he has focused on adaptive collaborative management, common property resources and improving rural livelihoods. He received the Queen's Award for Forestry at Buckingham Palace in 2005. 


\section{Acknowledgements}

For more reasons than we care to list, writing this book turned into something of an odyssey. While most of us found ourselves in Zimbabwe when we began writing this book a few years ago, the latter half of 2008 found most of us in the 'diaspora', either because of choice or necessity. However, our tardiness is as much a result of our own slow writing processes as it was a result of the Zimbabwean context within which, and later of which, we wrote.

We have Carol Colfer's constant support and mentoring to thank for the fact that this book has finally seen the light of day! Carol has been a fellow traveller on our journey through the twists, turns and loops of adaptive management from the very first day. Without her this book would never have been completed.

Our sincere thanks to the European Union, the Department for International Development (U.K.), the Swedish International Development Cooperation (SIDA) and CIFOR for providing the financial support that made various parts of the research that underpins this book possible. A special thanks to CIFOR for agreeing to publish our work in the 'ACM Series'. We would also like to thank the Forestry Commission (FC) and 
the Institute for Environmental Studies of the University of Zimbabwe, our key partners in the ACM research process, and the various officers who supported the work of CIFOR within the FC extension division.

Godwin Kowero and Peter Frost were integral parts of our 'team'. Our thanks are due to them for their generous support and advice, especially when we found ourselves in a tight corner intellectually. Their constant encouragement was a source of great strength to all of us. Don Gilmour, Irene Guijt, Doris Capistrano, David Kaimowitz, Ken MacDicken, Sibongile Baker (nee Sibanda), Margaret Sangarwe, Enos Shumba, Yemi Katerere, the late Sarah Mvududu, Bruce Campbell and Godfrey Nehanda all provided valuable advice and institutional support as members of various advisory or supervisory committees.

Each of the three case studies drew on different people for help. In Midlands Province, for Chapter Two, we thank Mkhululi Ngwenya, Matoso Gutura, Nyasha Poto-Joe, J. V. Muzvondiwa, S. Bonongwe, I. Mbire and the late Isaiah Mutasa. We would also like to thank community members in Ndarire, Gababe and Batanai villages whose insights and time were invaluable for this work. Special thanks in these communities go to the Resource Management Committee members and Lizwelabo Sibanda, Jevas Sithutha and Mike Chivanga who contributed immensely to the data and analysis. Our colleagues at CIFOR, Wavell Standa-Gunda, Happyson Mudavanhu, Sonja Vermeulen, Consillia Gwaka, Pauline Nechironga, Itai Chibaya and Bevlyn Sithole, now for the most part happily pursuing alternative careers, were contributors and companions for long stretches of the ACM journey. Chapter Three was only possible with the support of members of the Romwe and Mutangi communities and the Rural District Council who were actively involved in the action research process. Witness Kozanayi, Osman Mabhachi, Bruce Campbell and Karin Gerhardt contributed to various parts of the research. We are most grateful to VeCo for allowing us to use and publish the material in Chapter Four some eight years after the completion of their project. In this regard we would particularly like to thank Dr Godfrey Nehanda, who also read the preliminary drafts, and staff at the VeCo office for their support. We acknowledge the partnership 
role of the Mutoko district office of the Forestry Commission during the implementation of the project.

We thank our long-suffering families for their faith and support during the researching and writing of this book. We could not have done this without you!

Our final thanks go to the brilliant and supportive technical team that edited, formatted and finally published this book: Sally Atwater our editor, Gideon Suharyanto, Eko Prianto and Catur Wahyu who designed and laid out the book, Atie Puntodewo who provided most of the maps, Linda Yuliani who was our 'champion' at CIFOR, Maya Prabhu and Mark Havard for additional language editing and, once again, Carol Colfer for her leadership and for never giving up on us!

The Authors 


\section{Foreword}

This book will intrigue the scholar of collaborative interaction, enlighten the sensitive facilitator of rural development, and irritate the disciples of social engineering. Empirically grounded in three case studies taken from Zimbabwe, the analysis provides a vivid depiction of the constraints under which the rurally impoverished struggle both individually and collectively to maintain and improve their livelihoods. Given the current prominence accorded to poverty in Zimbabwe in the international media, readers will not be surprised to encounter its manifestations in these pages, where rural peoples struggle to make a living on an inadequate resource base left to them when colonialism expropriated much of the most fertile arable land for white commercial farming. The material consequences of this expropriation remain, and are exacerbated by population growth and urban-to-rural migration as formal sector employment shrinks in Zimbabwe's declining economy.

Poverty, however, cannot be properly understood if only its material aspects are considered. Colonialism imposed on the people of the land what in fact was a double expropriation; not only the loss of the most fertile land but also the loss of rights to determine the modes of husbandry and use of 
the resources on the land with which they were left. This impoverishment was staged. In part it was legal. Land remaining for indigenous occupation was state land, the state holding authority for planning, settlement and the use of natural resources. Local inhabitants were, in effect, wards of the state and thus deprived of the empowering impact of responsibility and authority over major aspects of their livelihoods. The early years of the colonial state government's presence tended to be indirect, depending heavily on customary authorities as a surrogate interface. Its presence in what eventually came to be known as "communal lands" became obvious only when commercially exploitable resources (e.g. minerals, wildlife and timber) were present in abundance. By the middle of the $20^{\text {th }}$ century, the government's bureaucratic presence in these communal lands became more obvious. Conservation and productivity concerns led to numerous pieces of environmental legislation, and the growth of agricultural and environmental extension services. The impact of these agencies has been mixed, but without question the technical advice of hardworking extension agents has had beneficial results in a number of dimensions. This positive assessment must, however, be balanced against the stultifying impact of an asymmetric relationship between government and communal land peoples, in which government generates and disseminates all knowledge and has complete power to dictate its uptake, while regarding local people as uncritical recipients of this knowledge. In such a relationship these peoples' abilities to experiment are curtailed; in effect they cannot practice science in the local context they know better than anyone else. This is profound poverty; the poverty of impotence, which may be far more corrosive to the human condition than material poverty. Considerable attention is rightly drawn in the introductory chapter to the abject material poverty currently found in Zimbabwe. However, the poverty of impotence imposed on rural peoples by colonialism, and perpetuated in the post-colonial period is not confined to Zimbabwe. For me, therefore, this volume is more than just a book on Zimbabwe; it is a book on approaches to an escape from the poverty of impotence, using case studies from communities in Zimbabwe under severe stress as a prism to delineate the details of causality. 
This expropriation of knowledge creation is, in part, a tactic to hold power at the political centre. It is also, however, the outcome of an epistemic techno-academic and techno-bureaucratic relationship involving universities, institutes, aid agencies, NGOs and government bureaucracies, all of which depend on their reputation for knowledge generation and dissemination for enhanced professional status. This establishment is not monolithic, frequently rifts occur within it, but its epistemologies tend to be fairly uniform. The science behind this establishment has tended to be linear and reductionist, suited to certain discrete issues, but also inadequate when dealing with systemic contexts involving social and biophysical interactions. In the 1990s, Complex Systems Theory emerged as an attempt to deal in science with issues of complexity and system randomness. At an applied level, and consonant with this conceptual shift, Adaptive Management began to be propounded as a managerial stance to accommodate change and surprise, and give resilience to institutional and organisational structures. More than simply a trial-and-error system, Adaptive Management requires experimentation, evaluation, consequent adjustment and iteration.

Consistent with these conceptual and implementational shifts, a number of initiatives have emerged which seek to facilitate the restoration of the functions of knowledge generation and local self-determination to rural peoples, where these have been expropriated or suppressed. Sailing under different names and acronyms, these initiatives may have somewhat different emphases, but the common profile is one which accords local society the lead role in collective problem identification, analysis, experimentation, implementation, evaluation and adaptation. The role of external agents is also modified. No longer the sole purveyors of knowledge, their involvement with local peoples is invited rather than imposed, directed rather than directive, facilitative rather than manipulative. Taken together these components are aimed at producing "social learning" which provides the foundation for resilience in the face of change and adversity. The case studies in this book represent a well-known version of this programme profile promoted by the Center for International Forestry Research (CIFOR) and styled Adaptive Collaborative Management (ACM). 
The profile of aims and approaches outlined in the previous paragraph is, of course, an abstracted ideal. Anyone with experience in collective rural management will recognise that its attainment is fraught with obstacles, which mean that its realisation is rarely complete and usually a matter of degree, purchased at the cost of long evolutionary time spans in social learning. Obstacles to the success of such initiatives are often organisational and institutional, or they may be due to deficiencies in human agency. However, since they directly or indirectly involve shifts in the control of resources, the greatest impediment to their attainment is likely to be political interest, often in a position to subvert progress through bureaucratic manipulation, cooptation or naked coercion. With such an array of obstacles facing them, it is not surprising that such initiatives take significant time frames to gain energy and momentum. Often they are judged prematurely, and, as the authors of Chapter 5 comment, the "entire approach often gets evaluated on the basis of projects that bear little resemblance to its distinguishing features."

One of the great virtues of this volume is that its analysis is based on three case studies of sufficient duration and historical detail to delineate the twists, turns and varying fortunes of each project. The fact that each is about woodland resources, and that all share a common emphasis on local initiative and collective action gives a unity to the volume, while the difference in the three contexts provides a comparative variety which enriches the analysis. The seven-year Mafungautsi case study (Chapter 2), spanning the longest period of reportage, has as its core the dynamic relationships between a state-run forest area and its communal neighbours. The Chivi District micro-catchment example (Chapter 3) is more focussed in scale, and concentrates on the variety of social actors and motivations involved in the visioning and initiation of woodland management. The Mutoko case study (Chapter 4) is the most analytically structured of the three, concentrating on the locus and motivations of decision making in tree management and propagation. Its section on local monitoring is something of a tour de force in its insight and attention to detail. 
As already noted, the time span of these case studies (from four to seven years) is sufficient to allow the authors to draw certain legitimate conclusions and to note what they term the "zigzags of pragmatic and commonsensical decisions" when the arbitrary seems more efficient than slower cycles of social learning and social consensus. Other sources of variation in the direction and performance of the case studies are noted, among these being the circumstances of inception, relationships with relevant government policies and their agents, degrees of communal cohesion, individual agency and the environing politico-economic context.

In assessing the impact of ACM, the authors use the rich data available to give a candid and convincing evaluation of the cases presented. Their evaluation is by no means an unqualified endorsement of either the implementation or the results observed. Evidence of material benefit is scant and equivocal; informational benefits were more in evidence. Institutionally, each case was found to involve only a small proportion of the populations of the communities concerned, producing a "fragmental" and possibly divisive impact. In execution, each case study deviated from the ideal model and in only one case were the links between design, process and outcomes clear. The analysis finds that in all three cases project interventions were prematurely terminated by political events in 2002, which effectively suppressed any further momentum towards communal land innovation in natural resource governance, and rendered impossible any facilitative activity by project personnel.

Taken as a whole, this presents a rather sombre picture of the convoluted and rocky road that ACM faces in its strategy to facilitate improvements in rural livelihoods through social learning and collective action. A combination of microsocial detail and macropolitical intransigence had conspired to neutralize many of the advances made. This assessment omits, however, one important dimension of the project results; what the authors refer to as the "transformational objective" of ACM. In the case studies, there is ample evidence of this transformation in the case of individuals; persons who found new avenues for innovation and assertiveness, sometimes extending well beyond project boundaries 
to other realms of social life. They were, in effect, manifesting signs of liberation from the poverty of impotence. There are also some instances where this transformational effect went beyond individual to collective dimensions, such as where, in the words of the authors, villages "weaned themselves beyond reliance on facilitation to independently craft resource use relations that applied not only amongst themselves, but also included people of other villages." Such examples are of fundamental importance since they manifest attributes which must be present if rural peoples are to properly confront poverty. The authors are correct to urge further research on the factors which enable institutional memory in such cases to outlive the support of facilitation.

The prevailing professional candour which pervades this small volume is revealing, and gives it a value greater than its size might imply. It will, of course, be read by those interested in the detail of the parlous conditions of Zimbabwe's contemporary rural poor. Its relevance is, however, far wider than Zimbabwe alone, its case studies having a panoramic breadth dealing with rural poverty, both material and subjective. It should be read by all who subscribe to its general premise that solutions to rural poverty must start from within the perspectives and actions of rural populations themselves. Those who would substitute for this premise quick-fix injections of material and technological aid should also read it to learn how essentially arrogant it is to ignore human innovation in the face of the poverty of impotence.

\section{Marshall W. Murphree}

Oak Park

Pietermaritzburg 3201

South Africa 


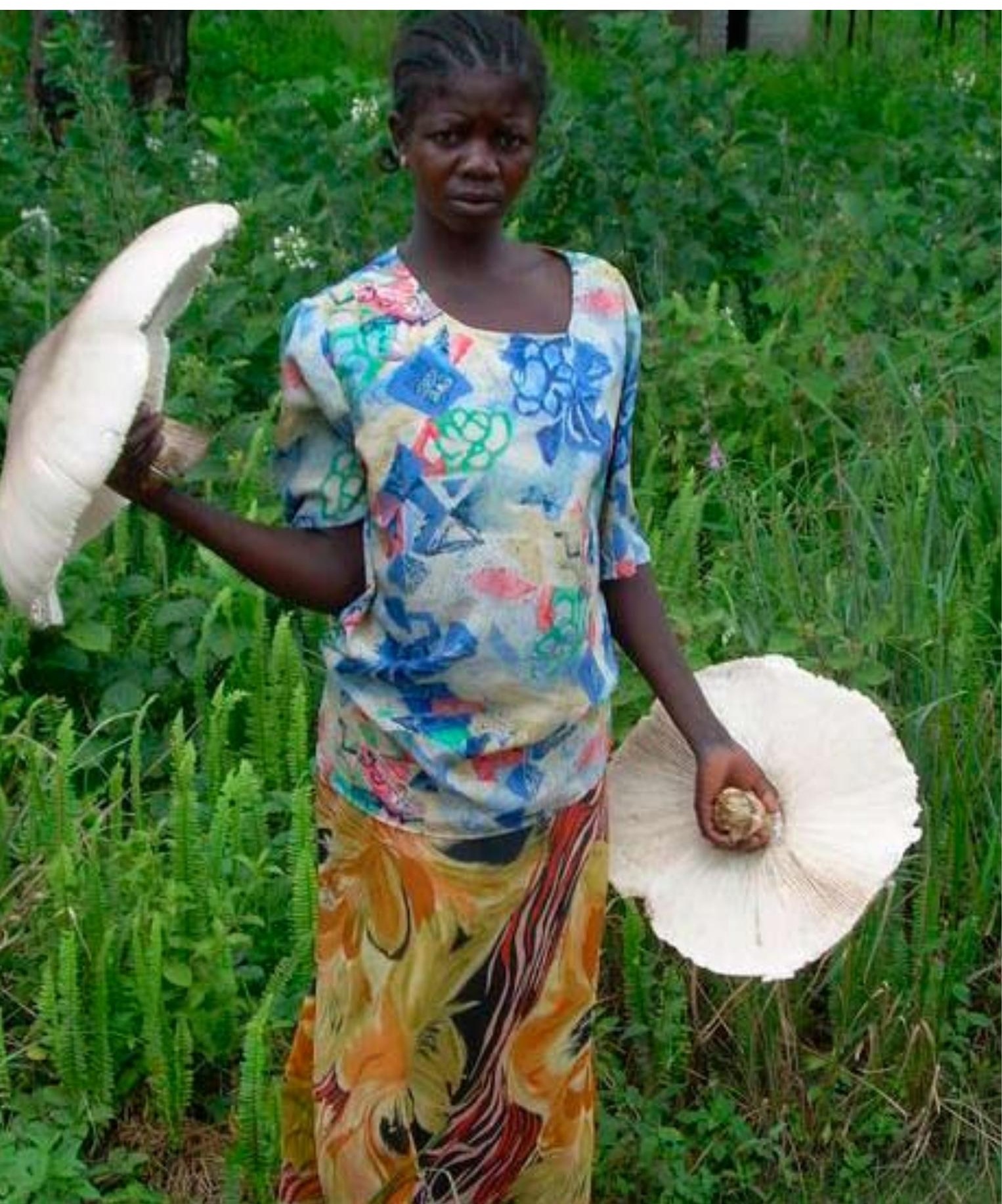




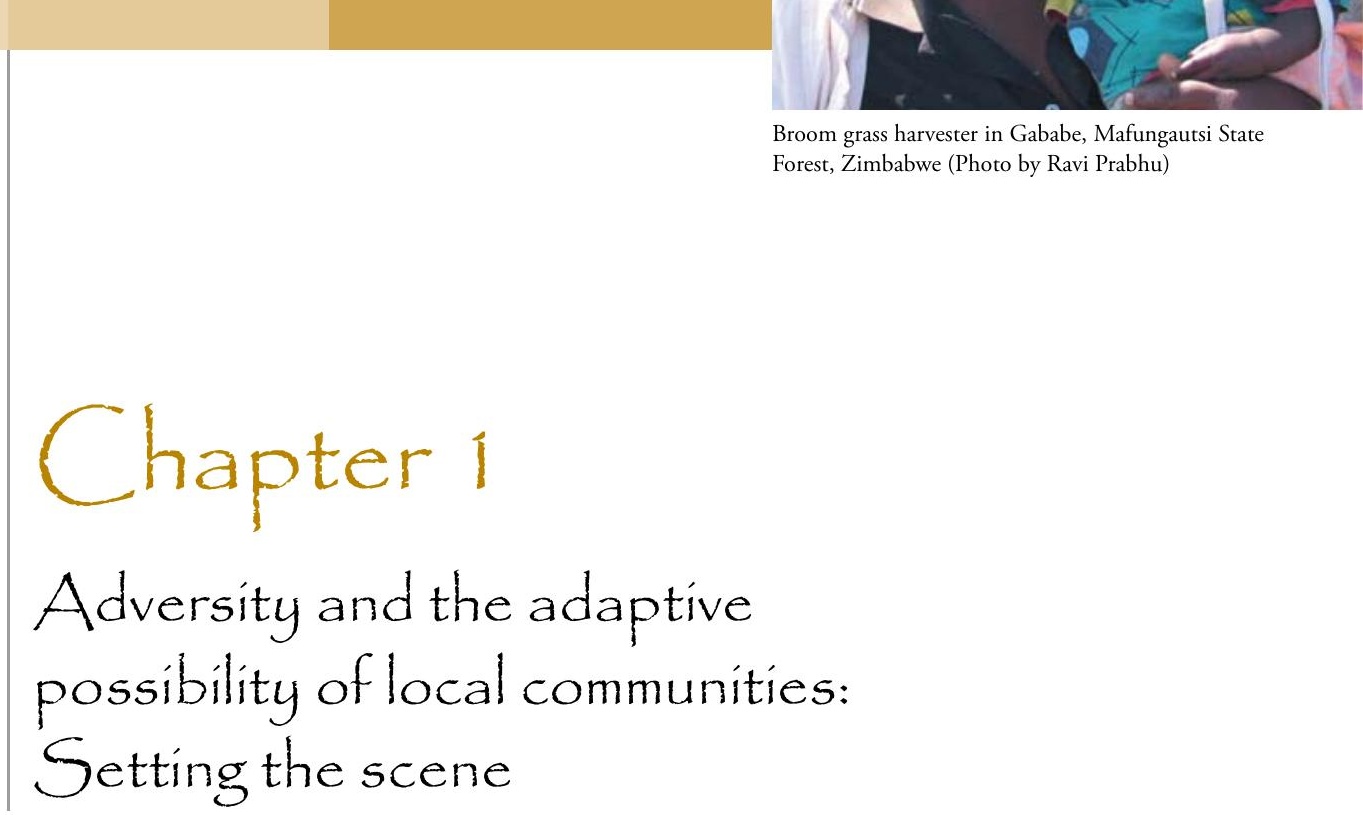

Ravi Prabhu

Frank Matose

"... the adaptive possibility of societies is the main source allowing them to survive in the long term, to innovate of themselves, and to produce originality."

Nicolis and Prigogine (1989 p. 242) 
n late 2008 the inflation rate in Zimbabwe exceeded 11,000,000 percent per year, becoming the highest in the world (http://edition.cnn.com/2008/ BUSINESS/08/19/zimbabwe.inflation/?iref=mpstoryview), having risen from 48 percent in the previous decade. Although the United Nations generally uses economic and human well-being indicators to evaluate the status of a country, natural resources indicators also point to deterioration (UNEP n.d.). The severe economic downturn in Zimbabwe has exacerbated the problems caused by HIV-AIDS, the prevalence of which among adults is estimated at 20.1 percent (UNAIDS 2006); the fourth highest rate in the world and second only to Botswana among neighbouring countries, although infection rates do appear to be falling. Zimbabwe's natural resources have also been subjected to severe pressure over the past decade and a half (FAO 2007). With a deforestation rate of 1.7 percent, or 313,000 ha per year, according to FAO (2007), Zimbabwe ranks ninth of African countries in annual deforestation (sixth if only countries with more than a million ha of forest are counted). Efforts to counteract the rapid rate of economic decline have entailed increased centralisation, often because the lack of commitment to decentralisation has made matters worse (Mandondo and Mapedza 2003; Mapedza and Bond 2006; Rihoy et al. 2007). These recentralisation trends represent a reversal in policy from the previous decades, which saw greater devolution of responsibility and often authority (Mandondo and Mapedza 2003). This is exemplified by the loss of previous gains in devolved wildlife management through CAMPFIRE, due to declining central government resources available for rural district councils (Rihoy et al. 2007; Mapedza 2008).

In this book we examine how some rural communities in forested landscapes in Zimbabwe have tried to cope with such challenges with the help of outside non-governmental organisations (NGOs) and research institutions. Our goal was to understand how natural resources have helped the people adapt and how, in turn, the natural resources have fared as a result. Against the backdrop of the apparent inability of central planning to deal with the complex challenges Zimbabwe faces, we hypothesise that adaptive management approaches offer an alternative strategy for local communities that are distant from the centres of government decision making. 
Many books and papers have been written about policy deficiencies in natural resources management in Zimbabwe, particularly with regards to forestry (Bradley and McNamara 1993; Nhira et al. 1999; Mukwekwerere 2000). However, only a few researchers, such as Clarke (1994), have attempted to document how change is indeed taking place through innovations in forest management practice in Zimbabwe. This collection of case studies (see Figure 1) provides insights into the contribution that adaptive management processes can make to managing resources under conditions of severe economic, social and ecological stress. Indeed, the extreme stress that Zimbabwe is now experiencing was foreshadowed in the mid-1980s, when, despite great strides forward in equity, economic growth began to falter. We argue in this book that to cope with economic stress, change is necessary, and it is more likely to lead to improvement if it takes place through participatory learning and action amongst stakeholders. We draw implications from the case studies with respect to the practice of adaptive management as well as policy formulation. To begin, we discuss the concept of adaptive management.

\section{Adaptive management}

Adaptive management was first articulated in the field of natural resources management by Holling (1978). The approach has gained currency within the areas of resources management and conservation ecology since the late 1990s (Gunderson et al. 1995; Gunderson and Holling 2001; Röling and Jiggins 1998; Ruitenbeek and Cartier 2001; Salafsky et al. 2001).

Simply put, adaptive management is an approach that leads to selfimproving systems of resource management based on:

» Improved flows of information;

" Decision making that follows from 'experimentation';

»Communication and negotiation amongst stakeholders; and

» Learning amongst groups that results in change in resources management systems. 


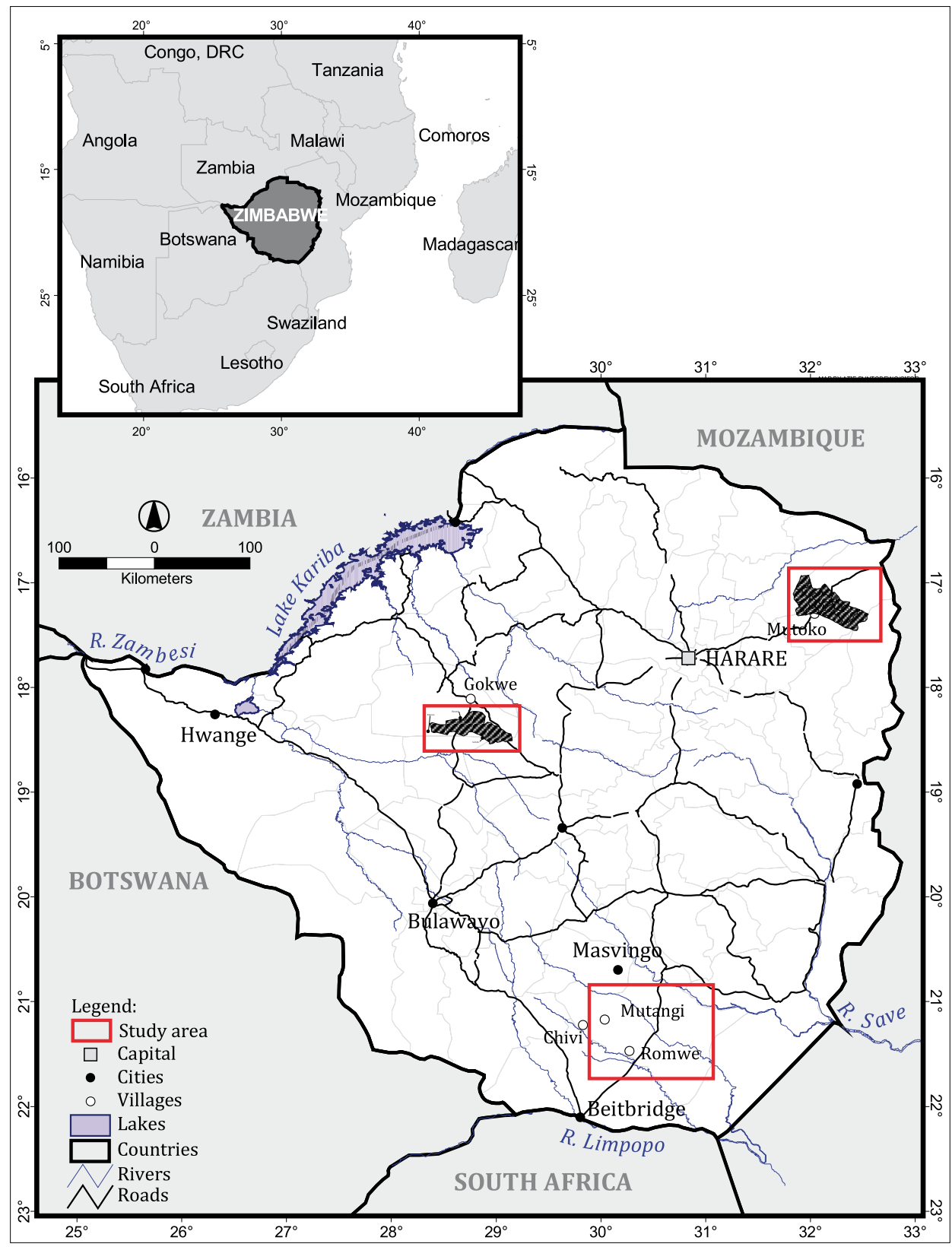

Figure 1-1. Locations of the three case studies in Zimbabwe 
The literature on adaptive management of natural resources, however, has few analyses or accounts of actual practice that can inform managers (Rogers 1998). This volume seeks to close that gap by providing analysis of three approaches employed by local communities to achieve adaptive management of natural resources in real situations, with the help of external facilitators. The processes observed in Zimbabwe are, we believe, generalisable.

The point of departure for adaptive management is the realisation that we are dealing with complex systems characterised by uncertainty and surprise (Ruitenbeek and Cartier 2001). This means that causes and effects are obscured by multiple interconnections, lag times and non-linear behaviours of interacting components (Sterman 1994). Consequently, making predictions about outcomes based on probabilistic approaches is difficult and often misleading. For managers, this suggests the need to plan for possible alternative outcomes and monitor the impacts of their actions, especially undesired side effects, and make adjustments where necessary. Thus, adaptive management explicitly factors in the expectation that plans may not achieve the intended target and that failure is an opportunity for learning and improvement. The approach is both cyclical and iterative in nature, and therefore both similar and different to trial-and-error approaches. Both approaches are iterative, but whereas trial-and-error systems leave innovation to happenstance, adaptive management builds on a body of theory related to learning, communication and resilience to design a structured approach to increase opportunities for generating originality and innovation.

Adaptive management also explicitly recognises scale-related emergent properties of systems. Thus, in keeping with system and hierarchy theories (Sterman 1994; Allen and Hoekstra 1992), outcomes at the local level are linked to those at higher levels of organisation, both influencing and being influenced by mesolevel and macrolevel policies. Unfortunately, in Zimbabwe today, policy is dominated by a command and control mindset (Lele and Norgaard 1996). In fact, the government of Zimbabwe has responded to forest management challenges by further consolidating 
decision making at the centre. For instance, major policy decisions in Zimbabwe now emanate from the Joint Operating Command, a policymaking body comprising mainly military and security elements (Bratton and Masunungure 2006).

In this book we are interested not only in the workings of conventional policy, but also in the effects of decision making at the grassroots level on higher levels of decision making. We draw on complex systems theory by referring to 'panarchies', whose behaviour is close to what we see in Zimbabwe today (Ruitenbeek and Cartier 2001). Although local-level decision-making processes may be either structured or ad hoc, the emphasis in this book is on the former, which offers more opportunity for retaining institutional memory and thus allows for iterative cycles of shared learning. Our approach is similar to Ostrom and Janssen (2002), who suggest that it is more helpful to view social-ecological systems as 'complex adaptive systems'. This means that there are continuous processes of organisation and reorganisation, and order emerges after agents change their relations and strategies in both predictable and unpredictable ways; that is, as people 'tinker with their strategies' (Ostrom and Janssen 2002 p. 15).

Adaptive management should therefore be understood to refer to a management approach to complex systems where decision making is based on incremental, experiential learning supported by active monitoring of the outcomes of those decisions and feedback from their effects (Jiggins and Röling 1999). Such understanding locates change in the way people relate to nature and their environment by embracing uncertainty, coping with risk and, most importantly, learning from their actions to improve their decisions. In our use of the term adaptive management, we are influenced by the concept of adaptive collaborative management (Ruitenbeek and Cartier 2001; Colfer 2005a,b; Prabhu et al. 2007), which is the subject of the case study by Mutimukuru et al. in Chapter 2. In this variant of adaptive management, two processes are stressed in particular: collaboration among diverse stakeholders, and selfmonitoring or 'collaborative monitoring' by the participants to enhance their ability to learn more quickly and effectively as a group. The emphasis 
on collaborative monitoring, as Mutimukuru et al. explain, stems from a need to construct a deliberate link amongst plans, actions and outcomes. This recognises that under conditions of uncertainty, most plans will result in unintended outcomes. Where resources are either communally managed or require collective action of some kind, it is important that learning is done in groups. This minimises the fragmentation of knowledge that leads to false conclusions, thereby preventing or diminishing possible conflicts. Collaborative monitoring thus establishes a critical link to social learning and collective action amongst groups whose major strength may lie in their social capital.

Collaborative monitoring and evaluation draw on trends encouraging internal learning, a desire to understand the impact of funding for participatory approaches, global calls for community involvement in the process of providing information to answer environmental challenges, the growing focus on 'learning organisations' and efforts to support participatory democracy (Guijt 2008). It aims to enhance internal learning processes that enable stakeholders to reflect on their past experiences, revisit their objectives and define their future strategies (Abbot and Guijt 1998; Guijt 2007, 2008). By encouraging stakeholders to go beyond data collection and gathering to reflection and analysis, collaborative management promotes self-reliance in decision making and problem solving by stakeholders, thereby enabling them to take action and adapt their management strategies. Guijt (2008 p. 304) warns, 'It is high time that monitoring is taken seriously if those involved in rural resource management are to benefit from the potential of feedback loops to further sustainability and equity'. Prabhu et al. (2007 p. 44) suggest for adaptive collaborative management to work in practice, groups weave through 'the spaces together by iterating back and forth between phases, and moving on cyclically when ready. Much of the iteration is in response to the complexities and "bumps in the road" of reality, such as the miscommunications, tensions, and power struggles that accompany processes of communication, negotiation, and collaboration'. 
Having explained what we mean by adaptive management, in the next section we discuss how the approach can be enhanced.

\section{Action research}

The case studies presented in this book all use an action research approach, a process that involves cycles of planning, action and critical reflection (Selener 1997; Kemmis and McTaggart 1988). The intention is to deliver insights and innovations that are relevant to the lives and interests of the groups engaged in the research and robust with respect to the environments in which they live; this relevance provides the incentive for the participating groups. The transaction costs of carrying out action research - that is, 'auto-experimentation', with facilitative support from researchers as documented in Chapters 2 and 3 - can be high because of the internalised costs of failure during experimentation, the time and material costs of negotiating consensus and the politics of negotiated decision making. Nevertheless, action research has often been demonstrated to result in transformative empowerment and results that prove useful to the participants, more often than is the case with conventional forms of research. Appropriate facilitation tends to reduce the transaction costs of organising and carrying out the action research and becomes a vehicle for bringing in appropriate external experiences and mediating social negotiation processes. In all three case studies discussed in this book, facilitation of various kinds was available.

As shown in the cases documented in this book, action research tends to take longer to deliver results than, say, an externally designed set of interventions because it usually takes place in a dynamic and complex environment that is subject to surprises. The path to a solution in an action research environment is seldom straight; instead, the process meanders or spirals through suboptimal solutions and small failures. Thus, any analysis of an action research project tends to present a snapshot of progress. At any given moment in time, the actors may be enjoying the fruits of a successful intervention or suffering the effects of a small 
reversal; they may find themselves closer to the goals they set or in fact further away. All three case studies dealt with in this book are examples of externally driven projects for research or development, constraining the action learning cycles by the 'artificial' time horizons of the projects. It is therefore important to exercise caution in drawing inferences from these experiences.

\section{Policy implications}

This book offers policy makers and practitioners case materials for how to effect change in resources management by recognising that policy change is a part of a cultural change process. We draw on more than six years of research and action in Zimbabwe to provide insights into resources management in Africa and beyond, since the issues and circumstances are not unique to Zimbabwe. We follow Ruitenbeek and Cartier (2001 p. 31) in emphasising that the role of policy and governance is to serve the protection of 'conditions for the emergence of adaptive management properties'. Essentially, we explore this question: How do you create conditions for the emergence of adaptive management in forested landscapes?

\section{Structure of the book}

In Chapter 2, Mutimukuru et al. analyse how adaptive management has been applied in a state forest in the Gokwe South District. They describe a version of adaptive collaborative management that was facilitated in Mafungautsi State Forest as a process of structured learning and action; a journey the end of which is not yet within sight. In fact, they take the view that the journey is far more important than its purported destination, and they analyse in detail the various segments of that journey, exploring its implications for the actors. They present insights into the cyclical process of adaptive management and discuss the contribution of approaches such as 'training for transformation' and collaborative monitoring to improving adaptive management. 
Chapter 3 examines livelihood options in a semiarid agricultural landscape in Chivi District, where woodlands have receded and are the vegetative cover only on rocky hills. Nemarundwe and Mutamba examine how long-term action research on improving livelihood options by a team of researchers from the University of Zimbabwe has affected social and human capital in the local community and how this in turn has affected management systems and local natural, physical and financial capital. The authors focus on two interventions aimed at improving adaptive management: one at a conceptual level, where a vision was being articulated by a group in the process of developing policies, and another at the operational level of selecting, planting and tending trees by individuals. The authors contrast these two examples to draw out lessons for adaptive management as a whole.

Chapter 4 documents the learning and adaptation that took place over a long period in one community in Mutoko using locally developed monitoring mechanisms for resource use. Chahweta and Mandondo analyse community responses to maintaining woodlands through engagement in adaptive management activities targeted at different groups of people and different areas (tenurial niches). The adaptive interventions included enrichment planting and reduced wood extraction in degraded woodlands, rotation harvesting in more well-wooded areas, tree planting and tree retention in homesteads and fields, as well as the promotion of energy conserving stoves among women's groups. The chapter analyses how people make decisions as they engage to manage resources.

Chapter 5 examines the implications of the different experiences in Zimbabwe and considers the experiences emerging from the case studies from several standpoints. The first concerns differences in structures and processes of the adaptive collaborative management interventions pursued in the cases. The second concerns how these differences in design affected the outcomes, as assessed through a set of questions resonating with the theory discussed in this introduction. The third does the same from the perspective of policy. The chapter ends by distilling a few lessons for refining both practice and policy. 


\section{References}

Abbot, J. and Guijt, I. 1998 Changing views on change: Participatory approaches to monitoring the environment. SARL discussion paper 2. International Institute for Environment and Development, London.

Allen, T.F.H. and Hoekstra, T. 1992 Toward a unified ecology. Columbia University Press, New York.

Bradley, P.N. and McNamara, K. (eds.) 1993 Living with trees: Policies for forestry management in Zimbabwe. Technical Paper No. 210. World Bank, Washington, D.C.

Bratton, M. and Masunungure, E. 2006 Popular reactions to state repression: Operation Murambatsvina in Zimbabwe. African Affairs Advance Access 2007 106: 21-45; doi:10.1093/afraf/adl024, September 2.

Clarke, J. 1994 Building on indigenous natural resource management: Forestry practices in Zimbabwe's communal lands. Forestry Commission, Harare.

Colfer, C.J.P. 2005a The equitable forest: Diversity and community in sustainable resource management. Resources for the Future Press/ CIFOR, Washington, D.C.

Colfer, C.J.P. 2005b The complex forest: Communities, uncertainty, and adaptive collaborative management. Resources for the Future Press/ CIFOR, Washington, D.C.

Dzingirai, V. 2003 'CAMPFIRE is not for Ndebele migrants': The impact of excluding outsiders from CAMPFIRE in the Zambezi Valley, Zimbabwe. Journal of Southern African Studies 29(2): 445-459.

Food and Agriculture Organization (FAO) 2007 State of the world's forests 2007. FAO, Rome.

Guijt, I. (ed.) 2007 Negotiated learning: Collaborative monitoring in resource management. Resources for the Future Press/CIFOR, Washington, D.C.

Guijt, I. 2008 Seeking surprise: Rethinking monitoring for collective learning in rural resources management. $\mathrm{PhD}$ thesis, Wageningen University, The Netherlands. 
Gunderson, L. and Holling, C.S. 2001 Panarchy: Understanding transformations in human and natural systems. Island Press, Washington, D.C.

Gunderson, L.H., Holling, C.S. and Light, S.S. (eds.) 1995 Barriers and bridges to the renewal of ecosystems and institutions. Columbia University Press, New York.

Holling, C.S. (ed.) 1978 Adaptive environmental assessment and management. John Wiley and Sons, New York.

Jiggins, J. and Röling, N. 1999 Adaptive management: Potential and limitations for ecological governance. International Journal of Agricultural Resource Governance and Ecology Introductory Lecture on Challenges for Adaptive Management.

Kemmis, S. and McTaggart, R. 1988 Introduction: The nature of action research. In: Kemmis, S. and McTaggart, R. (eds.) The action research planner (3rd ed.). Deakin University Press, Australia.

Lele, S. and Norgaard, R.B. 1996 Sustainability and the scientist's burden. Conservation Biology 10: 354-365.

Mandondo, A. and Mapedza, E. 2003 Allocation of governmental authority and responsibility in tiered governance systems: The case of environment-related laws in Zimbabwe. Working Paper Series No. 11. World Resources Institute, Washington, D.C.

Mapedza, E. 2008 Decentralisation outcomes in the context of political uncertainty in Zimbabwe: A comparative assessment from comanagement and CAMPFIRE and implications for policy. Paper presented at Workshop on Forest Governance and Decentralisation in Africa, Durban, South Africa, 8-11 April.

Mapedza, E. and Bond, I. 2006 Political deadlock and devolved wildlife management in Zimbabwe: The case of Nenyunga Ward. Journal of Environment and Development 15: 407-427.

Mukwekerere, M. 2000 Developing indicators based collaborative monitoring arrangements to promote adaptive community based forest management: A policy review prepared for CIFOR. Center for International Forestry Research Regional Office, Harare. 
Murombedzi, J.C. 1999 Devolution and stewardship in Zimbabwe's CAMPFIRE Programme. Journal of International Development 11(2): 287-294.

Nhira, C., Baker, S., Gondo, P., Mangono, J.J. and Marunda, C. 1998 Contesting inequality in access to forests. Policy That Works for Forests and People Series No. 5. International Institute for Environment and Development, London.

Nicolis, G. and Prigogine, I. 1989 Exploring complexity: An introduction. W.H. Freeman and Company, New York.

Ostrom, E. and Janssen, M.A. 2002 Beliefs, multi-level governance, and development. Paper presented at Annual Meeting of the American Political Science Association, Boston, Massachusetts, August 29-September 1.

Prabhu, R., McDougall, C. and Fisher, R. 2007 Adaptive Collaborative Management: A conceptual model. In: Fisher, R., Prabhu, R. and McDougall C. (eds.) Adaptive collaborative management of community Forests in Asia: Experiences from Nepal, Indonesia and the Philippines. Center for International Forestry Research, Bogor.

Rihoy, E., Chirozva, C. and Anstey, S. 2007 'People are not happy': Speaking up for adaptive natural resource governance in Mahenye. Occasional Paper Series No. 31. PLAAS, University of the Western Cape, Cape Town.

Rogers, K. 1998 Managing science/management partnerships: A challenge of adaptive management. Conservation Ecology 2(2): R1. http://www. consecol.org/vol2/iss2/resp1/.

Röling, N.G. and Jiggins, J. 1998 The ecological knowledge system. In: Rolling, N.G. and Wagemakers, M.A.E. (eds.) Facilitating sustainable agriculture. Cambridge University Press, Cambridge, U.K.

Ruitenbeek, H.J. and Cartier, C. 2001 The invisible wand: Adaptive comanagement as an emergent strategy in complex bio-economic systems. CIFOR Occasional Paper No. 34. Center for International Forestry Research, Bogor. 
Salafsky, N., Cauley, H., Balachander, G., Cordes, B., Parks, J. Margoluis, C., Bhatt, S.,Encarnacion, C., Russell, D., and Margoluis, R. 2001 A systematic test of an enterprise strategy for community-based conservation. Conservation Biology 15(6): 1585-1595.

Selener, D. 1997 Participatory action research and social change. Cornell Participatory Action Research Network. Cornell University, Ithaca, New York.

Sterman, J.D. 1994 Learning in and about complex systems. System Dynamics Review 10: 291-330.

UNAIDS 2006 Report on the global AIDS epidemic: A UNAIDS 10th anniversary special edition. UNAIDS Joint United Nations Programme on HIV/AIDS, New York.

United Nations. n.d. Millennium indicators database. Statistics Division. http://mdgs.un.org/unsd/mdg/.

http://edition.cnn.com/2008/BUSINESS/08/19/zimbabwe. inflation/?iref $=$ mpstoryview

http://www.thezimbabweindependent.com/index.php?option=com_conten

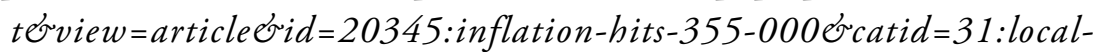
zimbabwe-stories\&ltemid $=66$

United Nations Environment Programme (UNEP) n.d. GEO data portal. http://geodata.grid.unep.ch/mod_table/table.php 
E

xclusionary forest management approaches have often caused conflicts and degradation of resources (Pimbert and Pretty 1995). A common characteristic of such approaches is that local people continue to access protected resources illegally. New approaches to forest management in developing countries seek to resolve such conflicts by simultaneously addressing both conservation and the well-being of communities living in and around the forest. Participation of local people in management processes is regarded as crucial for striking a balance between conservation and the improvement of human lives (Wilshusen et al. 2002; Brechin et al. 2002; Borrinni-Feyerabend 1996). Such people-centred projects have been given several names that are often used interchangeably: joint forest management, co-management, collaborative management, and shared forest management, to mention just a few.

However, many projects based on the participatory approach have resulted in neither effective conservation nor improvements in the lives of forestdependent people. This has fuelled debate on the effectiveness of involving local communities in resource management. Conservationists are calling for 'stricter enforcement of protection laws'; proponents of people-oriented approaches consider this a 'reinvention of the square wheel'-something that will never work (Brechin et al. 2002; Wilshusen et al. 2002; BorrinniFeyerabend 1996)—and accordingly are exploring more effective models of forest management. Responding to the need, in 1999 the Center for International Forestry Research (CIFOR) initiated its Adaptive Collaborative Management (ACM) Programme with research projects at multiple sites in Cameroon, Ghana, Zimbabwe, Malawi, Indonesia, the Philippines, Nepal, Kyrgyzstan, Madagascar, Brazil and Bolivia. The projects addressed the following questions (Prabhu 2003):

»Can collaboration among stakeholders in forest management, enhanced by processes of conscious and deliberate social learning, improve human well-being and maintain forest cover and biodiversity?

» What approaches, centred on social learning and collaborative action among diverse stakeholders, can be used to encourage sustainable use and management of forest resources? 
» In what ways do the processes and outcomes of ACM affect social, economic, political and ecological functioning, and how does this feedback reinforce or weaken forest management?

The ACM approach aims to 'strengthen and enhance processes of adaptation so that groups concerned have the capacity to adapt quickly and more appropriately to changes that confront them than through ad hoc trial and error' (Prabhu 2003 p. 12). To improve the adaptive capacity of groups in resource management, ACM focuses on three main elements: (1) strengthening social and human assets of groups; (2) enhancing shared learning and adaptation by stakeholder groups through the creation of opportunities to share their knowledge and experiences, so as to learn together and adapt; and (3) broadening the knowledge base upon which decisions are made by improving collaboration beyond immediate actors to other stakeholders as well as helping to identify who the other stakeholders are (Prabhu 2003).

ACM research activities in Zimbabwe were undertaken by CIFOR together with the Forestry Commission and local-level forest users to add value to a joint management initiative that had begun in 1993 in Mafungautsi State Forest. The CIFOR research started in 1999, and the ACM team worked as the main facilitators of learning processes until 2003, when the facilitation was handed over to the forestry officer responsible for the joint management project. The ACM research project aimed at shifting away from blanket prescriptions for solving problems and moving towards locally based sustainable forest management that could adapt to rapidly changing circumstances. The ACM team hypothesised that stakeholder' ability to improve management would be greatly facilitated if social learning arrangements were an integral part of the management system. Existing arrangements under the joint management venture did not entail a meaningful devolution of authority to forest users; rather, resources management committees under the control of the state forestry agency had responsibility. At the same time, the forest area had no history of collective action by local stakeholders with regard to the management of the state forest, in contrast to the case in Mexico (Bray et al. 2005) and Southeast Asia (Edmunds and Wollenberg 2003). 
This chapter analyses the ACM research process in Mafungautsi State Forest and its outcomes, and draws lessons for using the ACM approach, especially in politically volatile situations. It addresses three questions. First, does the ACM approach lead to improvements in both the resource condition and human lives? If yes, under what conditions? Second, what are some of the challenges of using the ACM approach? And finally, what lessons can be drawn from Mafungautsi State Forest for enhancing participation of local communities in the management of forest resources? The chapter starts by describing the context of the project and then the ACM research process, reflecting on the various steps taken. A section on the outcomes of the process is followed by a discussion of the above questions.

\section{Context}

The ACM research project and its outcomes in Mafungautsi State Forest, in Gokwe South District, can best be understood by situating it in the broader context of Zimbabwe.

\section{Political and economic situation}

State forests in Zimbabwe are mostly surrounded by densely populated communal areas, and land pressure complicates their management (Matose 2002). During the colonial era, from 1890 to 1980, communal areas (known as Native Reserves) for native Zimbabweans were created in dry, remote parts of the country, and the most productive land in the country was taken over by white settlers. This unequal distribution of land was one of the major causes of the guerrilla uprising by native Zimbabweans. To end the war, the British government brokered negotiations between the white settlers and the black masses that led to the Lancaster House Agreements and elections in 1980, which were won by Robert Mugabe, the leader of the Zimbabwe African National Patriotic Front (ZANU-PF). At Independence in 1980, one of the promises of the new government was to give land back to the people, through resettlement. The new government, however, was bound by 'sunset clauses' in the Lancaster House Agreement, 
which gave protection to white Zimbabweans during the first 10 years of Independence. These included provisions that the new government would not compulsorily acquire land, and that when required, the government would compensate property owners on a 'willing buyer, willing seller' basis (Human Rights Watch 2002).

By the 1990s, few people had been resettled, and the communal areas continued to be overpopulated. In 1999, disgruntled by the poor pace of land redistribution, war veterans, in a wave of farm invasions, took over land from the white farmers by force. The government, having failed to secure funds to buy land for resettlement, supported the land invasions and formalized it as the Fast Track Land Reform Programme in 2000. A new law permitted the acquisition of farms without any compensation to the farmers. From 2000 onwards, the political and economic conditions in the country deteriorated into what a UN envoy in 2005 dubbed an economic meltdown.

Because of those developments, Zimbabwe has become something of a pariah state, and field research on forest management and benefit sharing in the deteriorating economic climate was difficult. Gokwe being a stronghold for the ruling ZANU-PF party, the ACM researchers had to continually visit the ZANU-PF offices and also the local Office of the President to explain their work and assure both organisations that they were doing research and were not involved in politics. When organising workshops in the research areas, the team had to invite representatives from these two organisations to sanction the meetings and allay any suspicions about the activities. Failure to do this would have put them in danger.

Because of the economic meltdown and a blooming 'parallel market' for foreign currency, it has become difficult to quantify in U.S. dollars (USD) the real financial value of benefits that resource users obtain from their activities. This is mainly because of hyperinflation and the loss of value for the Zimbabwe dollar (ZWD) over time. To date, numerous exchange rates have been quoted: official figures (which up to the end of 2007 grossly overvalued the ZWD), parallel market rates, the UN rate, and those from the internet. For the sake of consistency and comparison, the team chose 
to use the realistic rates available from the following website: http://www. oanda.com/convert/fxhistory. The different ZWD amounts equivalent to one USD are presented in Table $2-1$.

Table 2-1. Exchange rates: Zimbabwe dollar (ZWD) to U.S. dollar (USD), 2001-20071*

\begin{tabular}{lrrrrrrr}
\hline & $\mathbf{2 0 0 1}$ & $\mathbf{2 0 0 2}$ & $\mathbf{2 0 0 3}$ & $\mathbf{2 0 0 4}$ & $\mathbf{2 0 0 5}$ & \multicolumn{1}{c}{$\mathbf{2 0 0 6}$} & \multicolumn{1}{c}{$\mathbf{2 0 0 7}$} \\
\hline January & 55.19 & 57.37 & 57.09 & $\mathbf{8 1 9 . 0 2}$ & $5,516.73$ & $91,621.13$ & 259.13 \\
\hline February & 55.14 & 57.36 & 56.84 & $1,023.23$ & $5,500.40$ & $98,920.45$ & 259.24 \\
\hline March & 55.14 & 57.38 & 56.86 & $4,077.18$ & $5,500.40$ & $99,322.75$ & 259.09 \\
\hline April & 55.18 & 57.33 & 208.62 & $4,470.30$ & $5,780.40$ & $99,258.17$ & 258.72 \\
\hline May & 55.17 & 57.28 & 813.92 & $5,199.76$ & $6,561.72$ & $101,270.19$ & 257.85 \\
\hline June & 55.90 & 57.23 & 814.47 & $5,327.84$ & $9,092.96$ & $101,227.16$ & 255.23 \\
\hline July & 55.97 & 57.08 & 814.44 & $5,314.58$ & $11,145.30$ & $101,292.00$ & 255.12 \\
\hline August & 56.04 & 57.13 & 820.37 & $5,440.04$ & $18,701.26$ & $10,037.10$ & 255.00 \\
\hline September & 56.25 & 57.14 & 816.04 & $5,498.97$ & $24,293.37$ & 259.57 & $19,518.95$ \\
\hline October & 57.32 & 57.08 & 817.71 & $5,421.86$ & $27,264.17$ & 259.43 & $30,685.23$ \\
\hline November & 57.26 & 57.07 & 814.22 & $5,616.19$ & $62,161.39$ & 259.13 & $30,653.08$ \\
\hline December & 57.33 & 57.05 & 815.26 & $5,665.85$ & $76,856.13$ & 259.17 & $30,697.59$ \\
\hline
\end{tabular}

* In August 2006, the Zimbabwe reserve bank governor redenominated the currency by a ratio of 1 to 1,000 (dropping three zeroes).

Source: $h t t p: / / w w w . o a n d a . c o m / c o n v e r t / f x h i s t o r y$

\section{Research site}

Mafungautsi State Forest lies in Gokwe South District of Zimbabwe's Midlands Province (Figure 2-1). The third-largest indigenous state forest in the country, it covers an area of 82,100 ha on a plateau of deep Kalahari sands. It is a source of four rivers: Sengwa, Ngondoma, Mbumbusi and Lutope. Mafungautsi supports miombo woodland, a widespread vegetation type found in Central Africa that is characterised by trees of the leguminous genera Brachystegia, Julbernardia and Isoberlinia (Wild and Barbosa 1967; Timberlake et al. 1993). Unlike closed teak forests, which are stable but not resilient to disturbances, the open and mixed miombo at Mafungautsi is relatively resilient and suffers little mortality despite major disturbances from fire and frost (Geldenhuys 1977; Childes and Walker 1987). The excellent drainage of the sands favours woody plants over grasses. Consequently, grasslands occur only in river valleys, where 


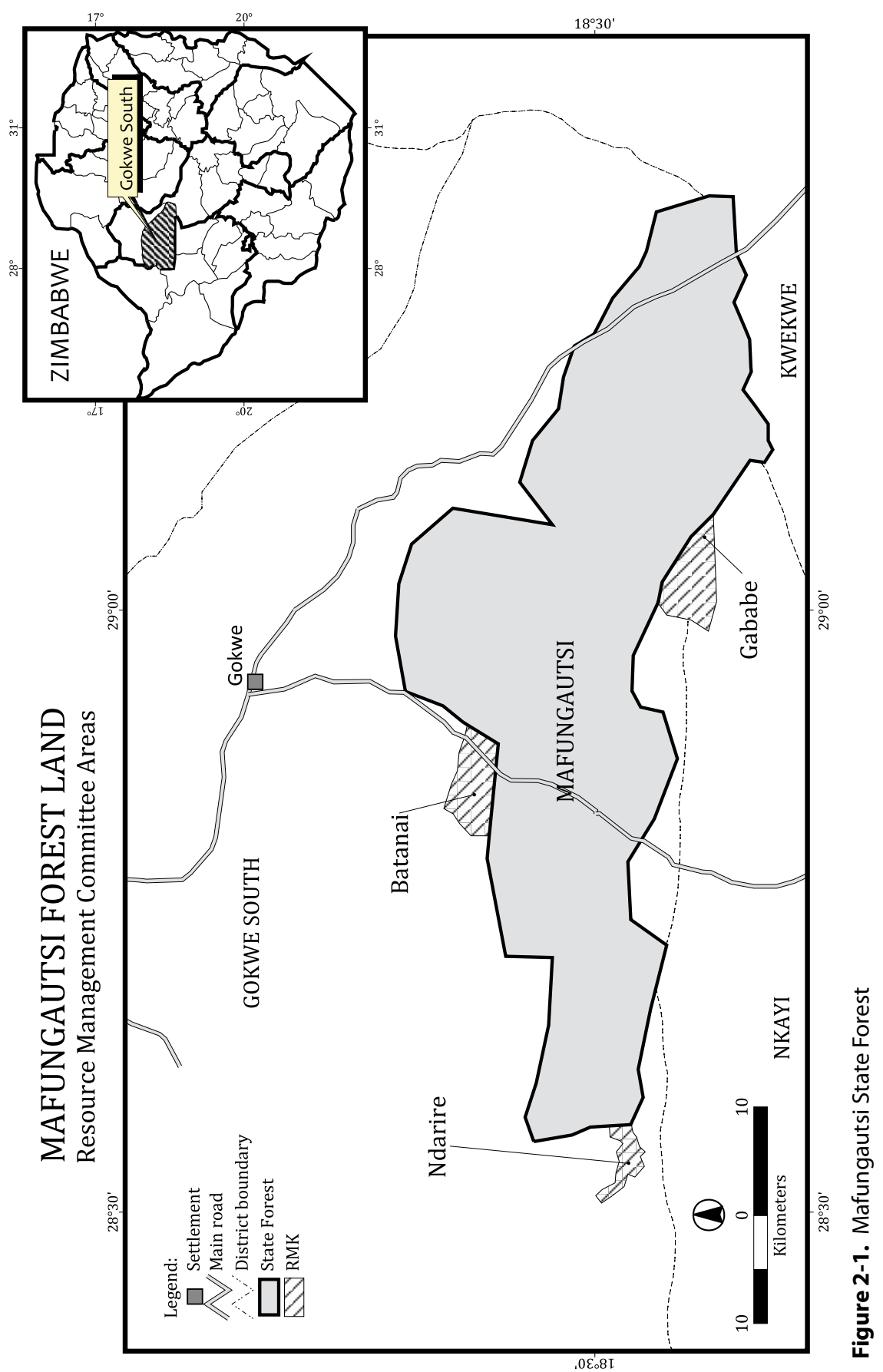


shallower water tables enable grasses to outcompete woody species. Grass cover is low in the woodlands on the plateau for the same reason.

The land cover types in Mafungautsi State Forest are shown in Figure 2-2. In general, human intervention and other disturbances may change the structure and diversity of the forest (Childes and Walker 1987; Vermeulen 1994). However, these factors can be manipulated to maintain the forest in the state most suited to meeting stakeholders' needs. The forest is a source of several resources, including thatch grass (Hypparrhenia femitina), broom grass (Aristida junciformis), honey, mushrooms, timber, wild animals, poles, herbs, tea leaves and firewood. The existing co-management arrangements, which allow local communities to harvest and derive benefits for certain non-timber forest products while ensuring that no overharvesting or illegal removals take place, preclude them from extracting high-value resources, such as timber, poles and wild animals. This reduces legal opportunities for local communities to generate income, and it also encourages illegal harvesting.

\section{Mafungautsi Forest Land}

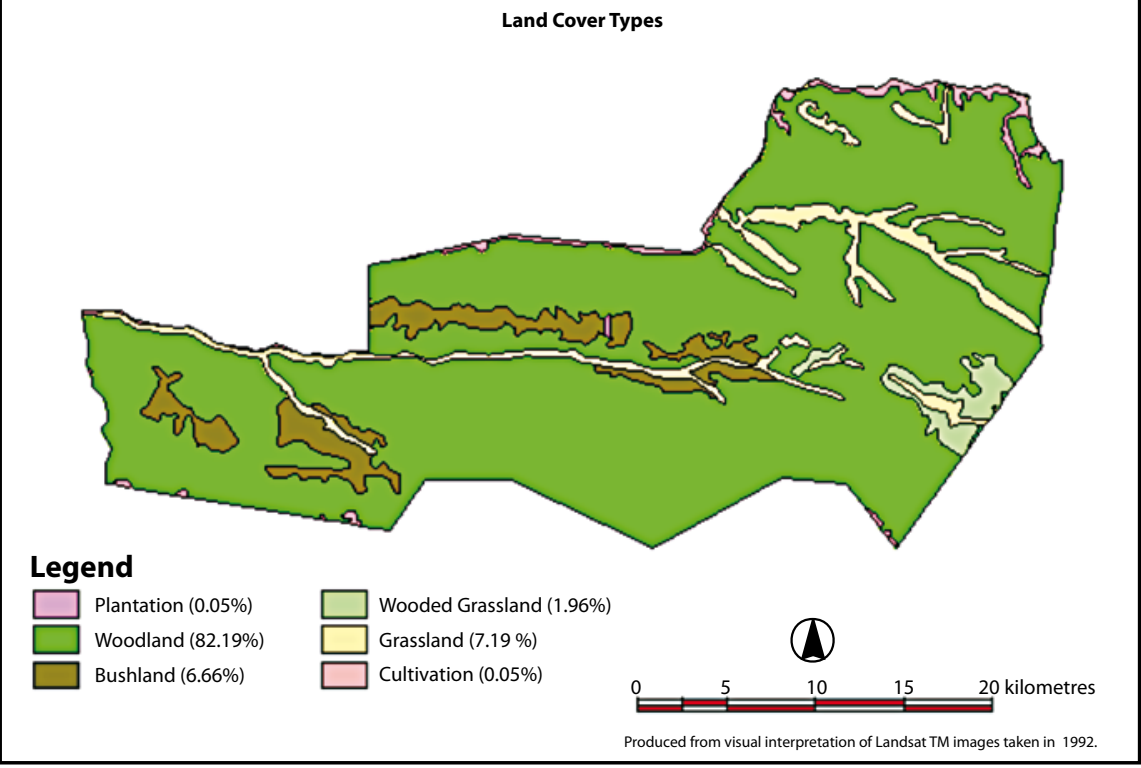

Figure 2-2. Mafungautsi land cover types 
State forests in Zimbabwe were established for commercial timber, wildlife production, preservation of biodiversity, and protection of ecosystems and water catchments (Piearce and Gumbo 1993). The forests are legally under state control, and their management is vested in the government's Forestry Commission. The Forestry Act, which governs the management and use of state forests, does not recognise any role for other stakeholders, in either use or management. However, such exclusionary management regimes have not protected the forests from tenurial and use pressures. In the past few decades, the gazetted forests have increasingly become a contested resource (Bradley and McNamara 1993; Matose 2002). Although the state may view the state forests as sources of revenue (from the extraction and sale of timber resources), retreats for recreation and repositories for genetic material, local communities perceive these forests as their own customary land and an inalienable basis of their livelihood and cultural and spiritual needs (Matose 1997; Matzke and Mazambani 1993). Increasingly, communities living on the margins of the forests are demanding that their traditional and political rights to the land and its resources be recognised (Matose 1994).

To ameliorate conflicts, in 1993 the Forestry Commission initiated the Resource Sharing Project in Mafungautsi, with assistance from the Canadian International Development Agency. This was a pilot project to test co-management as an alternative to exclusionary state control. The experiment was considered important for determining whether such people-centred approaches were worthwhile. Subsequent reviews revealed largely disappointing results because the resource management committees, established as vehicles for community involvement in the management of the forest, remained 'sleeping' and not equal partners in the project (Nhira et al. 1998). In essence, the protectionist approach remained intact. This was the situation when CIFOR's ACM project began in 2000.

Considering budget constraints and the intensive nature of the research, the ACM team focused on just 3 of the 14 resource management areas around the forest: Ndarire (under Headman Chirima), Gababe (under Chief Njelele) and Batanai (under Headman Ndlalambi) (Figure 2-1). 
These sites were selected by a small team consisting of the researchers, district-level stakeholders and traditional leaders from the Gokwe South District. Detailed profiles of the three sites are provided in Table 2-2. People in Batanai and Gababe harvest thatch and broom grass under the Resource Sharing Project, and ACM activities focused on how to sustain these resources whilst improving the lives of the resource users. In Ndarire, ACM activities addressed the challenge of making timber resources part of the Resource Sharing Project.

\section{Stakeholders in Mafungautsi}

The team identified two major groups of stakeholders. Districtlevel stakeholders included the Forestry Commission, Rural District Council, the Ministry of Youth, Gender and Employment Creation, the Department of Natural Resources, the Department of Agricultural Research and Extension Services, and the District Administrator. Except for the Department of Agricultural Research and Extension Services and the Forestry Commission, all the other district-level stakeholders were not actively involved in facilitating processes in communities. Local-level stakeholders included traditional leaders (chiefs, headmen and village heads), village development committees, ward development committees, resource management committees and their sub-committees, resource user groups (initiated under the ACM research process), local councillors and local extension agents. Though classified as consisting of homogeneous stakeholders, each committee actually had its own internal dynamics (such as those arising from traditional leadership structures).

\section{ACM team}

The composition of the ACM team changed over time, partly as a result of economic pressures and partly to improve the gender balance in the team. Throughout the research period, a team leader was responsible for steering the research process. The CIFOR global ACM project coordinator, who had helped develop the ACM concept, was based at the CIFOR Harare office and played a major role in influencing the research process. Before and after each field trip, the researchers met with the team leader and the 


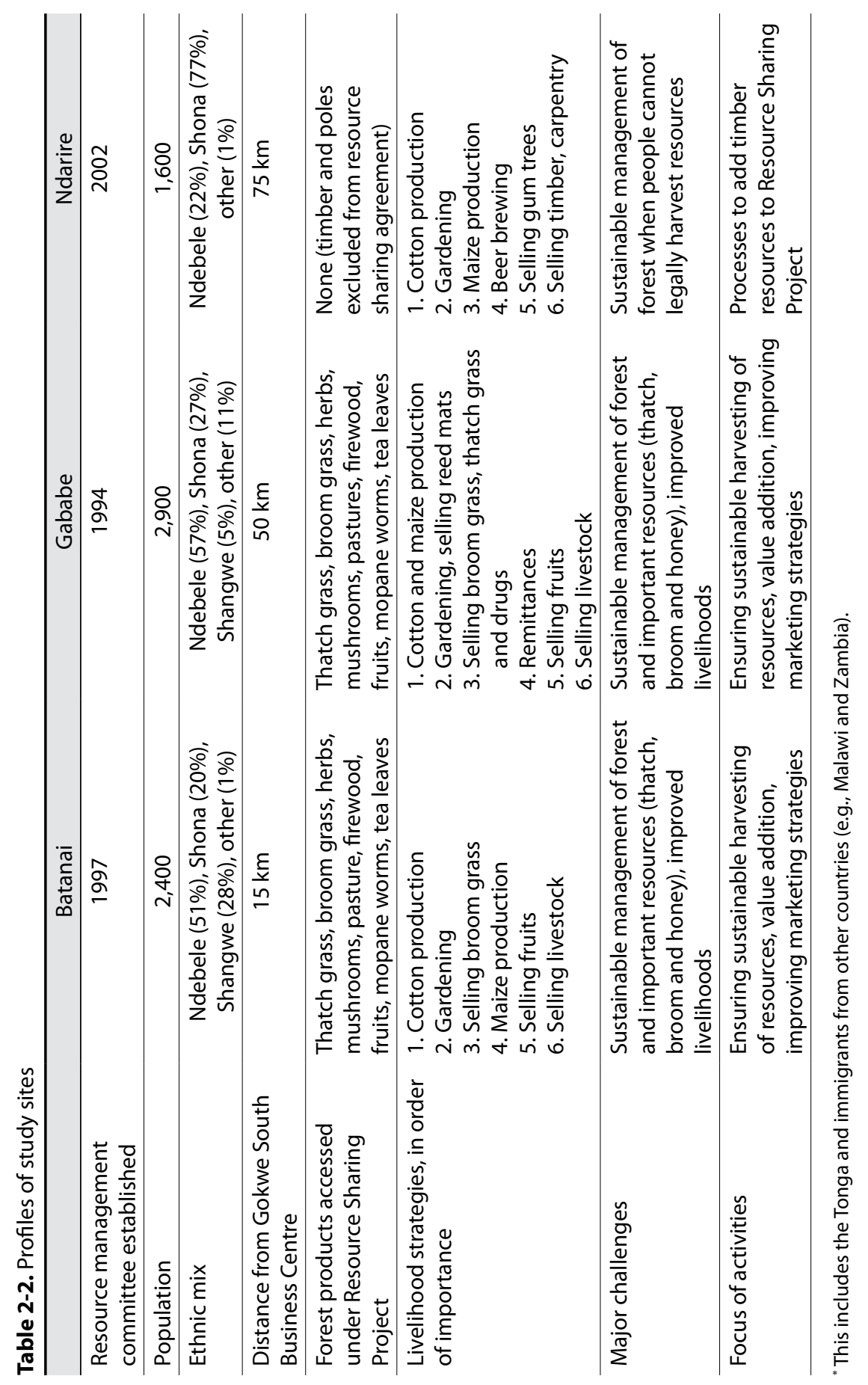


ACM project coordinator to discuss their progress and reflect on their findings. The team used the lessons learned to determine the next research steps as well as to adjust their strategies; that is, the researchers used the same reflective action learning cycles as the local community members involved in the research. At its peak, the team consisted of five researchers with complementary backgrounds in ecology, sociology and economics.

\section{ACMresearch process}

Adaptive collaborative management ${ }^{1}$ has been described as an engine for innovation and adaptation (Prabhu et al. 2007). In CIFOR's use of the term, it is similar but not identical to adaptive co-management, as used by Armitage et al. (2007) and Plummer and Armitage (2007), although in its early literature on this subject (Ruitenbeek and Cartier 2001) CIFOR too used that term. As defined by CIFOR, ACM is a qualityadding approach whereby stakeholders interact, negotiate a vision for their resource and consciously undergo shared learning in developing and implementing their plans; it has been extensively described in Prabhu et al. (2007), Colfer (2005), and Ruitenbeek and Cartier (2001); see also Chapter 1 (of this volume) and Box 2-1. Implementation is jointly monitored, and outcomes are observed and reflected upon to generate lessons for subsequent activities. Management processes are influenced by deliberate lessons generated by stakeholders involved in joint learning processes (Prabhu et al. 2007). Stakeholders make conscious efforts to communicate, collaborate and seek opportunities for joint learning about the impacts of their actions (Colfer 2005). ACM leads to self-improving systems of resource management based on improved flows of information, decision making that follows experimentation, communication and negotiation among stakeholders, and learning among resource users that alters management systems (Chapter 1, this volume).

Driving ACM is participatory action research, a process through which members of a group or community identify a problem, collect and analyse information, and act upon the problem to find solutions and promote 


\section{Box 2-1. Three pillars of adaptive collaborative management}

Communication and creation of a shared vision: Developing a shared vision for the resource is crucial for ACM because the vision acts as a reference point for stakeholders as they work their way through decision-making processes. The vision must be shared by the stakeholders if they are to participate in collective action; effective communication is the basis for developing a shared vision.

Social learning: Learning in ACM is different from traditional approaches: it is learning not just by individuals but by multiple stakeholders who bring together their experiences, perspectives, knowledge, values and capacities for critical reflection to generate joint understanding and address shared problems and challenges (MacDougall et al. 2002).

Joint action: Because of the complex nature of natural resource management and the multiple stakeholders involved, joint action needs to be taken if improvement is to result.

From Prabhu et al. (2007).

social and political transformation (Selener 1997). Participatory action research combines three principal activities: research, education and action. It can stimulate social learning by bringing different groups together through a conscious and deliberate cycle of inquiring, observing, reflecting, planning and acting (Buck et al. 2001), and it can help generate means of communication and learning that are appropriate for the collaborators. Participatory action research allows local people to participate in and control all phases of the research (Guerrero 1995), from problem identification to planning, monitoring and decision making to re-planning, in a cyclical loop (Fisher 1995; Greenwood and Levin 1998; Allen 2001).

In Mafungautsi, facilitation of learning and collaboration took place at both the local and the national levels. Stakeholders operating at different scales, including individual resource users, resource user groups, resource management committees, forest bureaucrats and researchers, were deliberately included in reflection and learning cycles. The learning and reflection evolved from small loops that gradually grew into bigger and 
more formal loops. Facilitation was adopted on the premise that it would enhance adaptive action, since human societies have inherent abilities to adapt. Catalyzing adaptive action was promoted through a variety of learning platforms - such as meetings and other deliberate opportunities for stakeholders to share experiences and learn together - aimed at unlocking local stakeholders' potential.

The steps taken in the ACM research process included the following: researchers' entry, selection and training of community partners, carrying out context studies, empowerment training and formation of resource user groups, and participatory action research to address problems identified by the resource user groups. The participatory action research process is summarized in Figure 2-3. The steps taken in the ACM research process

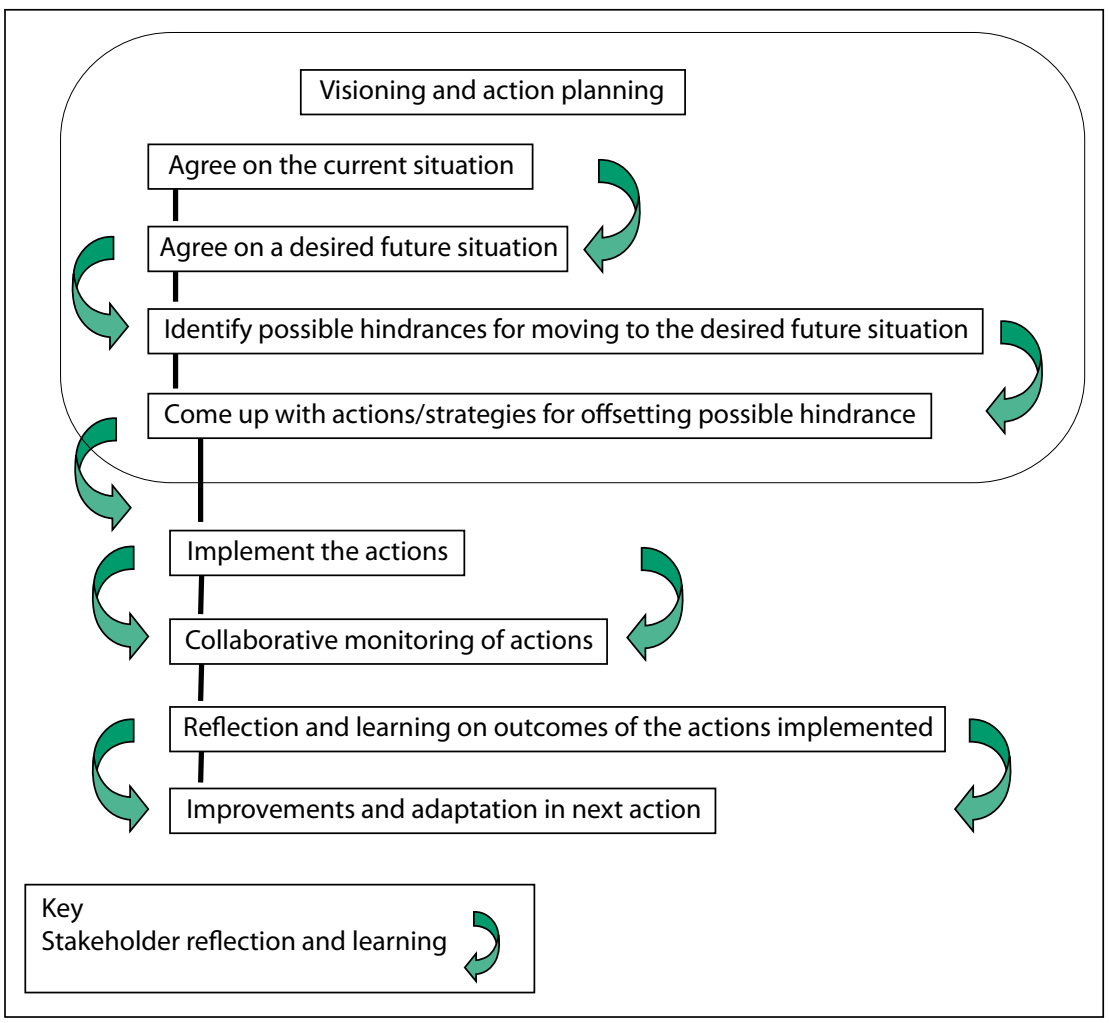

Figure 2-3. The participatory action research process 
are presented and discussed below. At each step there is a critical reflection of what happened, and the key lessons learned are shared.

\section{Researchers' entry}

Getting the strategy right for the 'entry' was considered crucial by the ACM team because it would greatly influence the relationships that would evolve with stakeholders, including local community members and district-level officials with mandates and interests in the forest. The Forestry Commission officers at Gokwe South District Business Centre, as the mandated authorities, provided the initial entry point through which other district-level stakeholders involved in the Mafungautsi Resource Sharing Project were identified. A meeting was held with those stakeholders to identify which communities and study sites would take part in the ACM project. The district-level meeting proved an eye-opener for the district-level stakeholders, who acknowledged that they had gained more knowledge at this meeting about the Mafungautsi project. Even though they had a stake in the project, they had not been formally involved or given regular updates. For the ACM researchers, establishing relationships with the district stakeholders was important to gain their support for the project. Getting the support of district-level stakeholders proved crucial when (political) problems arose during later fieldwork.

The ACM researchers began by promoting the development of mutual respect and trust among stakeholders. A small team, comprising one CIFOR researcher, the Forestry Commission officer, one rural district council officer and councillors responsible for the study sites visited all the selected communities to identify local-level stakeholders, consult with local leaders and introduce the project in a series of meetings. In Ndarire and Gababe, building rapport took about a year and a half due to a long history of mistrust in working with the Forestry Commission. At that early stage, communities in the research areas identified ACM researchers with the Forestry Commission, and people were hesitant (Box 2-2). 


\section{Box 2-2. Questions and comments from Ndarire community members}

- 'How do we know that you are not the Forestry Commission coming under cover?'

- 'Our relationship with the Forestry Commission gives us no room; the situation is not conducive for us and them to discuss and meet both our needs.'

- 'We and the Forestry Commission are always running away from each other. When we saw your vehicle, some of us ran away.'

- 'Is this research going to find out whether people are going to get any help from the Forestry Commission?'

- 'We held a meeting sometime ago with the Forestry Commission and nothing came out of it; how is this meeting different from the one we had?'

- 'If we agree to carry out the ACM research with you, are we going to have a social contract, as evidence of commitment from both of us?'

- 'Are benefits from Mafungautsi Forest going to accrue to us or to people from elsewhere?'

- 'Is your organisation related to the Forestry Commission?'

- 'Will we not regret this in the future? What assurances are you going to give us?'

- 'Is your research focussed on the people only, or the people and the Forestry Commission?'

Confusion arose because the ACM researchers were accompanied by the Forestry Commission officer during their initial visits, and at that stage the team was using the Commission's vehicle. Team members tried to clarify their position and build trust with the communities, which required adeptness and transparency. A great deal of time during meetings in the next year and a half was spent explaining the nature of the research and the relationship between the Forestry Commission and CIFOR. In the interest of building institutional memory for the project as well as ensuring transparency, the team members also made all records of meetings available to the communities.

Building relationships with the district-level stakeholders during the early stages of research was a good strategy, especially in Zimbabwe's politically volatile situation. However, using a Forestry Commission vehicle during the introductory visits to research sites was a poor choice, especially since the Resource Sharing Project was not popular. It made community members suspicious of researchers' intentions, especially in Ndarire and 
Gababe, where the relationship between the communities and the Forestry Commission was particularly bad. However, as the research progressed, the relationship between community members and the Forestry Commission did improve, and community members no longer seemed to mind whether the researchers drove a CIFOR or a Forestry Commission vehicle.

\section{Selection and training of community partners}

The ACM team members, who were based in Harare, about $300 \mathrm{~km}$ from Gokwe, stayed at Gokwe South Business Centre when conducting field work. As they were not living in the communities, they selected one person from each site to help facilitate meetings during their absence and also help with data collection. To select these 'community partners', researchers asked local communities to identify people they thought possessed certain qualities that the team suggested. The team later trained the community partners in skills and techniques required for conducting research ${ }^{2}$. The community partners had incentives to facilitate learning processes since they received an allowance from CIFOR, but stopped facilitating these processes when the project ended. For institutionalising learning processes, it would have been better to build the capacities of established structures like the resource management committees, which would continue to use these skills after research ended.

Even though the researchers encouraged communities to include women, the community partners chosen in all three sites were men. This was probably due to local cultural factors, since women who take active roles in public meetings may be considered lacking in morals. Some user groups consisted of women only, and it was difficult for male community partners to work with them because the women's husbands were uncomfortable with the arrangement. With empowerment training and other interventions helping local stakeholders challenge their norms and values, there might have been an opportunity to create gender-balanced community partner teams and build women's capacities. This opportunity was not realised by the ACM team, however, and despite preaching the 'gospel' of adaptive management, the researchers themselves were not always so adaptive. 


\section{Context studies}

The context studies provided an important opportunity for both researchers and communities to share information and knowledge about current resource use and the constraints to further development. The studies were divided into (1) an ecological survey to quantify the resources (mainly timber) in the forest and assess the rate of tree cutting for timber and honey harvesting; and (2) a socioeconomic survey to identify the institutions working in the study sites, types of resources extracted from the forest and where they were found, and problems faced by communities in collecting and utilizing forest resources. The socioeconomic survey was carried out using participatory rural appraisal techniques. At least one participatory rural appraisal meeting was held at each of the three sites.

The context studies helped team members understand the existing situation and strategise on the entry points and interventions to undertake. They also shed light on stakeholder dynamics, which was useful for selecting which groups to work with. Despite helping ACM team members to understand the context and local stakeholders to reflect on their situation, the context studies did not generate critical information for measuring change in the ACM project. For example, it would have been helpful to have generated baseline information for the indicators that were later identified by resource users for measuring progress toward the goals they set.

Following the context studies, report-back sessions were organised so that researchers could present their findings, get feedback from communities and discuss the implications of those findings. For example, at Batanai, when reporting on biophysical findings, the ecologist had concluded that all tree stumps represented trees cut for timber by poachers, but it turned out that some were the result of past logging by timber concessionaires.

The report-back sessions also gave community members an opportunity to reflect on the findings, and to learn and rethink their management strategies. For example, community members were surprised to learn that 
they were losing trees as a result of honey harvesting. People talked about the long time it took for trees to grow and the loss when these trees were cut illegally for the sake of harvesting honey. It was alleged that those who cut trees for honey harvesting were in a hurry, burned rubber tyres to smoke out the bees (smoke from rubber was said to be toxic to bees) and did not put out their fires. After the feedback session with the researchers, community members discussed ways of dealing with the problems and agreed to embark on beekeeping projects promoted by the Forestry Commission so that honey could be harvested without destroying valuable trees (Mutimukuru et al. 2005).

At the Batanai report-back session, the researchers had intended to shy away from the sensitive land issue. To their surprise, people brought it up because they felt it was high priority and needed to be addressed. Members of the ruling party passionately chronicled the history of Mafungautsi, highlighting how people were forcibly evicted from Zanda plateau and other portions of Mafungautsi Forest in 1986, because of dissident activities in the area. They wanted the researchers to help the people who had already moved back into the forest ${ }^{3}$ by facilitating processes to formalize the occupation. Other people at this meeting opposed the idea of formalising the forest settlements. The ACM team members felt the land issue was beyond the scope of their research and decided to concentrate on the forest resources. This turned out to be a mistake as more and more people continued to settle in the forest, threatening ACM activities.

\section{Empowerment training}

The context studies revealed people's passivity and general lack of confidence in their involvement in managing forest resources, perhaps attributable to the instrumentalized manner in which local communities had been involved in forest management in the past. During initial discussions with ACM team members, resource users in all the research sites elaborated on the numerous problems they faced but appeared unable to find solutions. Admittedly, this might have been intentional, to make outsiders solve their problems for them. The team members also observed that women rarely 
participated in any resource management meetings, mainly because of cultural stereotypes, in which prominence in the public domain indicates a lack of good manners. Only 5 (12 percent) of the 40 people who attended the ACM introductory meeting in Batanai area, for example, were women. ACM, however, requires all segments of the community, particularly those perceived as weak, including marginalised groups, to participate actively throughout the whole process. There was evidence of teamwork and innovation within the communities. For example, women tended to harvest broom grass in groups, thus sharing the burden of the physical strain. The ACM team members therefore decided to intervene by building on these identified strengths. An inclusive approach was also adopted in all the facilitation work, with researchers making conscious and deliberate efforts to ensure that previously marginalized groups had opportunities to attend workshops, express themselves and take the lead in issues that concerned them. For example, when organising for a visioning exercise, the researchers selected two women (who according to the wealth ranking exercise conducted during the context studies were amongst the poorest people in the village) and helped them develop their own visions for the forest resource in the coming two years. These women later presented their visions to the rest of the resource users and facilitated the whole group to come up with its vision. This gave the two women confidence. The ACM researchers also organised a one-week empowerment workshop called Training for Transformation ('T for T'), using a technique that had been successful elsewhere in Zimbabwe (Murwira et al. 2000). The workshop took place at Gokwe Business Centre, and selected representatives from the research sites, including women, other marginalized groups and the Forestry Commission officer responsible for the Resource Sharing Project, were invited to participate. Even though the ACM team invited an equal number of women to the workshop, only 10 (25 percent) of the 40 participants were women.

Training for transformation, based on Paulo Freire's philosophy (Freire, 1970), encourages change to be driven by the people affected rather than by outsiders. In this approach, transformation comes not from pouring 
knowledge into an empty head but rather from a process that offers hope and sets realistic expectations (Hope and Timmel 1995). For the ACM team, $\mathrm{T}$ for $\mathrm{T}$ was a suitable intervention to overcome the inertia among forest users in Mafungautsi Forest because it could overcome the root causes of fatalism and apathy among the poor (Hope and Timmel 1995). The workshop was conducted in a participatory manner, with extensive use of visual techniques, games, stories and short plays to explain the six principles of $\mathrm{T}$ for $\mathrm{T}^{4}$. The workshop challenged local communities to look critically at their situation and realise that they had the power to change it. Facilitators used a range of tools, including stories to help workshop participants reflect on and challenge their 'mental models' of their contexts and behaviours. At the beginning of the workshop, community members lacked the confidence to discuss issues concerning them. For example, when asked to give his views on what could be done to improve the lives of local stakeholders in the Resource Sharing Project, one participant said, 'It's you who should tell us, as you know everything. We do not know anything ourselves'. However, as the workshop progressed, people opened up and began to discuss important issues with the Forestry Commission officer on an equal footing, and all stakeholders began to learn from one another.

Participants, as part of their action plans, decided to report on the $\mathrm{T}$ for $\mathrm{T}$ workshop to their communities and organised meetings where they presented proceedings and shared information (especially photos and illustrations). In Batanai, women, who never used to speak during meetings were among those giving reports. One woman surprised many people with her articulate speech when narrating what had happened during the workshop and lessons learned. After the $\mathrm{T}$ for $\mathrm{T}$ workshop, the women's participation in forest management processes increased significantly. For the thatch and broom grass resource users, women dominated the meetings in both Batanai and Gababe (Table 2-3). The percentage of women attending workshops outside their communities also increased. For example, 55 percent of workshop participants at a criteria and indicators workshop organised by CIFOR researchers were women. 
Table 2-3. Attendance of women at resource management meetings and workshops

\begin{tabular}{lccc}
\hline Meeting or workshop & $\begin{array}{c}\text { Women } \\
\text { attendees }\end{array}$ & $\begin{array}{c}\text { Total } \\
\text { attendees }\end{array}$ & $\begin{array}{c}\text { Percentage of } \\
\text { women }\end{array}$ \\
\hline $\begin{array}{l}\text { Thatch visioning and action planning } \\
\text { meeting, Batanai, July 2001 }\end{array}$ & 16 & 27 & 59 \\
\hline $\begin{array}{l}\text { Criteria and indicators workshop, } \\
\text { Gokwe Business Centre, July 2001 }\end{array}$ & 16 & 29 & 55 \\
\hline $\begin{array}{l}\text { Broom grass action planning meeting, } \\
\text { Batanai, September 2001 }\end{array}$ & 21 & 23 & 91 \\
\hline
\end{tabular}

Clearly, the empowerment training was effective in boosting women's participation. However, some unintended outcomes were experienced as well. For example, most of the workshop participants in Batanai became active supporters of the opposition party, and some even became polling agents during the 2002 presidential elections. When researchers arrived for their next field work session, they began by visiting people who had attended the empowerment training workshop. Consequently, local politicians considered the researchers advocates for the opposition party, and this was dangerous. Before they could continue with their work, Gokwe South District stakeholders had to explain to local politicians that the researchers were not involved in politics. Local community members who had become activists for the opposition party also faced problems. For instance, the community partner for Batanai discovered that ruling party members were planning to beat him up, so he had to run for his life. The ACM team members were in Harare and were unable to help him. He returned home when things had settled down, but local politicians were not happy to see the ACM team continuing to work with him. Resource user group meetings were eventually banned in Batanai following passage of the Public Order and Security Act ${ }^{5}$ just before the 2002 presidential elections.

\section{Resource user group formation}

The context studies also revealed that not all community members were interested in forest-related issues. The ACM team decided to initiate the formation of groups comprising people who had an interest in a particular 
resource. Residents in the study sites were invited to join these resource user groups. The groups were flexible: individuals joined in or dropped out as and when they wished. Resource users were also free to join any of the other groups, and could belong to more than one group. Initially, perhaps out of curiosity, several people came to resource user group meetings and participated in the early stages of the research process. Most people dropped out as time went on, and only a few remained and participated in all stages of the research. Members of the resource user groups had opportunities to share their experiences and learn from each other in order to avoid making the same mistakes.

In Batanai and Gababe, resource user groups focused on thatch grass, broom grass and honey. Resource users in the Ndarire area mainly harvested poles and timber in the forest. Since these two resources were outside the resource sharing agreement, it was difficult for the ACM team to facilitate the formation of groups that focussed on them. However, three months after the team's visit to Ndarire, a 'poles and timber' group had been formed by resource users on their own initiative. The group members asked the ACM team to help them deal with some of the problems they faced. Their major problem was that harvesting poles and timber was illegal, and they wanted to negotiate with the Forestry Commission for the legal right to harvest these resources.

Working with resource user groups was difficult, particularly as socioeconomic and political conditions in the country worsened. Membership of groups fluctuated over time, thus slowing the process. For instance, some resource users migrated to neighbouring countries in search of a living, whilst others shifted to illegal gold panning. Some of those who left the groups had major roles in implementing the action plans that had been developed. Most new members lacked background understanding and had to be updated so they could contribute. Nevertheless, user groups were small and easy to manage because all their members had similar interests. Resource users themselves were excited about joining the groups, as it was the first time they had met specifically to discuss shared 
problems and seek joint solutions. Most of the problems they faced, such as resource degradation, could not be solved by individuals, but required joint action.

\section{Participatory action research with resource users}

Due to high levels of disillusionment over the Resource Sharing Project, the ACM team had to encourage people to take an active role in addressing their problems. The chosen tools for doing so were scenarios and visioning ${ }^{6}$, which stimulate creative ways of thinking to help stakeholders break out of established patterns and better adapt to the future. Members of resource user groups were asked to describe their hopes for the resource in the coming two years using the following criteria: status of the resource, number of people harvesting the resource, harvesting methods, availability of markets, price of the resource (both permitting and selling prices), revenue from the resource and, finally, rules and regulations governing use of the resource.

In preparation for the visioning exercises, the ACM researchers carefully selected a few resource users and helped them develop their own visions, which they then presented to other resource users. In Batanai, presentations by two women were so passionate that other community members were surprised to hear such eloquence from 'reserved and withdrawn' people who had never spoken before, let alone made presentations in public meetings. Besides inspiring the rest of the resource users to come up with a common vision for their resource, these women gained confidence ${ }^{7}$, and continued to participate in subsequent meetings.

After developing their visions, resource users were asked to describe the current situation (using the same criteria they had used to come up with their visions), with regard to their resource. An example of the current and future scenarios developed by the Batanai beekeepers' group is given in Table 2-4. 
Table 2-4. Beekeepers' current and future scenarios in Batanai

\begin{tabular}{|c|c|c|}
\hline Indicator & Current scenario (2001) & Future scenario(2003) \\
\hline $\begin{array}{l}\text { Participation in } \\
\text { beekeeping }\end{array}$ & $\begin{array}{l}30 \text { out of } 375 \text { households; few } \\
\text { women }\end{array}$ & At least 187 households \\
\hline $\begin{array}{l}\text { Knowledge and } \\
\text { skills }\end{array}$ & $\begin{array}{l}\text { Resource users have little } \\
\text { knowledge of beekeeping }\end{array}$ & $\begin{array}{l}\text { Resource users have } \\
\text { considerable knowledge and } \\
\text { skills in beekeeping }\end{array}$ \\
\hline $\begin{array}{l}\text { Beekeeping } \\
\text { methods }\end{array}$ & $\begin{array}{l}\text { Some resource users employ } \\
\text { poor quality hives, harvest honey } \\
\text { without protective clothing and } \\
\text { use smoke from burning tyres }\end{array}$ & $\begin{array}{l}\text { All resource users use } \\
\text { sustainable Kenyan Top Bar } \\
\text { hives, wear protective clothing } \\
\text { and use non-lethal smoke } \\
\text { and sustainable harvesting } \\
\text { methods }\end{array}$ \\
\hline $\begin{array}{l}\text { Rules and } \\
\text { regulations }\end{array}$ & None & $\begin{array}{l}\text { Clear rules and regulations } \\
\text { for beekeeping, enforced } \\
\text { consistently and rigorously }\end{array}$ \\
\hline Processing & $\begin{array}{l}\text { People process their honey as } \\
\text { grades A, B and C; little honey } \\
\text { achieves A standards }\end{array}$ & $\begin{array}{l}\text { Resource users have skills to } \\
\text { process most honey to meet } \\
\text { standards for grade A }\end{array}$ \\
\hline Markets & $\begin{array}{l}\text { People travel (more than } 300 \mathrm{~km} \text { ) } \\
\text { to sell honey; local market is not } \\
\text { developed }\end{array}$ & $\begin{array}{l}\text { No resource users travel to } \\
\text { far places to sell honey; well- } \\
\text { developed market exists at } \\
\text { Gokwe }\end{array}$ \\
\hline Annual income & ZWD $17,000.00$ (USD 308.10) & ZWD 40,000.00 (USD 724.90)* \\
\hline
\end{tabular}

Group members were then asked to identify things they thought might hinder them in achieving their future scenarios. For the Batanai beekeepers, for example, these hindrances included market location, market size, types of hives being used, prices of planks and lack of cooperation amongst users. The Batanai broom grass resource users identified unsustainable harvesting methods as a possible hindrance to their ideal future.

The resource user groups then came up with action plans to deal with the possible hindrances they had identified. The Batanai beekeepers' action plan, for example, included sharing knowledge on beekeeping, organising monthly meetings to plan prices and markets and monitor progress, and working closely with the resource management committee. The Batanai 
broom grass resource users identified activities for promoting harvesting by cutting, which they knew from experiments was more sustainable than digging, in spite of the market demanding brooms made from dug grass as they were considered more durable. Activities included informing resource management committee members whenever someone was seen digging broom grass rather than expecting committee members to monitor harvesting themselves, and having people pay the permit price after harvesting so that committee members could determine how the grass had been harvested. To deal with the problem of market demands, resource users suggested several strategies: broom grass harvesters (both inside and outside the Batanai resource management area) cooperating and only selling cut grass brooms, resource management committee members negotiating with the Gokwe Rural District Council to prohibit the sale of dug grass brooms, and broom grass harvesters coming up with new bundling methods to make cut grass brooms more durable.

After devising action plans, the resource user groups proceeded to implement the proposed actions. For example, the beekeeping group organised meetings where people shared their knowledge on beekeeping. At one meeting, the resource management committee chair shared what he knew about honey harvesting with the rest of the beekeepers:

"You must not harvest honey when it's too cold because this kills young bees.

» During the hot season, harvest honey in cooler weather because if it's too hot, the bees become angry and sting you.

»You need a helper to hold the honey while you are harvesting. It is difficult to harvest honey alone.

»You should not burn tyres to smoke out bees when harvesting honey because you will kill them. You can use cattle dung smoke to render bees harmless.

» You must not mix cattle and donkey dung when preparing smoke for harvesting honey as it will make the bees more aggressive.

»You must not make noise when harvesting honey.

»You must not beat the beehive when harvesting honey as this will also make bees angry. 
»You must not harvest all the honey; leave some for the bees.

» If you make the bees angry, you should leave and come back later when they have settled down.

» There is a time for harvesting honey. You should not harvest when there are young bees around, as the bees will sting you.

The Batanai broom grass group, in its efforts to encourage sustainable harvesting of the grass, organised a workshop to learn about a new, decorative bundling method. The Forestry Commission officer also attended this workshop. Resource users together with the Forestry Commission officer later decided to market the new brooms jointly at the annual provincial agricultural show in August 2004 with the Forestry Commission officer transporting the brooms. Eight of the thirty-two decorated cut brooms were sold at a higher price of ZWD 50 each (USD 0.88) during the show, and the remaining 24 brooms were sold at the Forestry Commission office for the same price. At the same time, undecorated cut brooms were selling for ZWD 8 each (USD 0.14) in Gokwe Centre.

Broom grass resource users in the Gababe area also pursued an aggressive marketing strategy by teaming up and travelling to distant places to sell brooms at higher prices. In June 2003, for example, Mrs Sibanda made a profit of ZWD 246,000 (USD 302.04) after selling her 500 undecorated cut brooms at a Harare market for ZWD 600 (USD 0.74) per broom ${ }^{8}$ (Table 2-5). The brooms were selling locally for ZWD 200 (USD 0.25) each, so if she had sold them at the local market, she would have made ZWD 100,000 (USD 122.78). By teaming up, women who had not been allowed to travel alone could now participate, since their husbands felt confident they would be safe in the group.

The benefits of learning and collaboration extended beyond the three resource management committees enjoying facilitated processes. For instance, once the Batanai broom grass resource users had come up with new bundling methods for making better brooms, grass collectors in other areas quickly followed suit and adopted the new techniques. 
Table 2-5. Mrs Sibanda's balance sheet for sales of undecorated cut grass brooms, June 2003

\begin{tabular}{lrr}
\hline & ZWD & USD \\
\hline Gross income & & \\
\hline 500 brooms @ ZWD 600 each & 300,000 & 368.34 \\
\hline Expenditure & & \\
\hline Accommodation, 5 days @ ZWD 500 per day & 5,000 & 3.07 \\
\hline Food, 2 days @ ZWD 200 per day & 1,000 & 1.23 \\
\hline Transport of brooms to Raji (by Scotch carts) & 15,000 & 18.42 \\
\hline Transport of brooms from Raji to Harare & 15,000 & 18.42 \\
\hline Personal transport to Harare & 18,000 & 22.10 \\
\hline Total expenditure & 54,000 & 66.30 \\
\hline Net profit & 246,000 & 302.04 \\
\hline
\end{tabular}

Participatory experimentation also took hold in Gababe. Broom grass resource users undertook an initiative to reduce harvesting conflicts while monitoring their resources by dividing their grass area into plots subject to formal monitoring regimes. The resource management committee pegged the plots so that demarcations were visible and clear to resource users. The users decided to collect data on the quantities, height and thickness of grasses from each plot and to look for trends. These variables were their indicators for sustainability of resource use. The results of this monitoring were used to track changes to the resource base so that any necessary corrective measures could be taken (Mutimukuru et al. 2006). Such ecological assessments must be linked to long-term changes in weather and rainfall patterns for them to yield meaningful results. Due to the high costs involved in the rigorous monitoring process, resource users ended up monitoring only height and growth rate, which were easy to measure; height was especially important because the market prefers long brooms.

In Ndarire, in an effort to get timber included in the Resource Sharing Project, the Forestry Commission officer, with financial support from CIFOR, organised a look and learn tour to a Nyagadza carpentry project in Chipinge. Two Forestry Commission officers, the provincial forest extension manager for Midlands Province, and representatives from 
five resource management committee areas around Mafungautsi Forest visited the project to learn how the communities were managing and monitoring their woodlots and implementing a timber harvesting system. This was a big learning opportunity for both the Forestry Commission and the communities, since the harvesting of timber by local people is a contentious issue. Following the trip, the two Forestry Commission officers administered a questionnaire to establish, among other things, the number of harvesters, their qualifications, tools and skills, and volume of timber harvested per season. This was followed by another survey to quantify the amount of timber available in the forest and the feasibility of allowing timber harvesting by Mafungautsi communities, along the Nyagadza model. The Forestry Commission officers were supportive of the idea and later shared the findings with the Commission's head office. This was one step that could influence the policy on timber harvesting in Mafungautsi and other state forests, where licences to harvest timber had been given only to outside timber logging companies.

In implementing their action plans, resource users also had opportunities to reflect on their actions, to learn, adapt and improve their next steps. Unfortunately, by the time the ACM project came to an end in 2003, researchers had not yet determined whether resource user groups had realised their 2003 visions, but the team did note some economic benefits for individual resource users. However, due to worsening economic hardships in the country at the end of the project, most resource users had left their areas in search of a living.

\section{Initiating and implementing collaborative monitoring}

Realising that monitoring was essential for generating information on whether the Mafungautsi stakeholders were moving towards their goals, the ACM team initiated collaborative monitoring processes. With the researchers as facilitators, user groups set up their collaborative monitoring systems. First, they identified the existing monitoring processes and tried to build on them, making them more systematic. The steps followed in setting up the collaborative monitoring system are presented in Box 2-4. 


\section{Box 2-4. Setting up the collaborative monitoring system}

- Survey. A survey was conducted to identify existing monitoring arrangements so as to determine how best to intervene and initiate a collaborative monitoring system.

- Framework. Collaborative monitoring was defined, and the steps to be followed in devising a monitoring mechanism for Mafungautsi were identified. The ACM team members discussed the framework with the Forestry Commission officer and after some negotiations came up with an agreed framework.

- Stakeholders' perceptions. Even though most stakeholders initially had a negative view of monitoring, after the negotiation processes they agreed that it should cover ecological and human well-being, as well as sharing and reflecting on the information and learning together to improve management practices.

- Presentation of results. The findings of the discussions with various stakeholders were presented at a general community meeting to get other views on the proposed framework for monitoring, the roles of each stakeholder and how they related to each other, and the way in which stakeholders would share their monitoring results, reflect on them and learn together. At this community meeting, stakeholders came up with a draft terms of reference for the newly formed monitoring sub-committee, which highlighted the linkages with other stakeholders and possible platforms that could be used to share information.

- Workshop. Lastly, a workshop was organised at which representatives from all the resource management committees around the forest finalised the monitoring framework and the terms of reference for the monitoring sub-committee. They agreed that the monitoring system was important and they would adopt or adapt the system in their respective areas. Provision was made for flexibility so that monitoring could be site-appropriate and need-driven rather than be a blueprint. Stakeholders also suggested translating the terms of reference for the monitoring sub-committee into the vernacular to make it easy for community members to understand.

Adapted from Mutimukuru et al. (2006).

Setting up collaborative monitoring processes was time consuming because several stakeholders participated at each stage in their development. Although the ACM project came to an end in 2003, before the collaborative monitoring could be implemented, the ACM researchers were able to observe some of what happened during follow up research work. 
In Batanai, the collaborative monitoring system generated important information for decision making by resource users. For instance, before the grass harvesting season, the collaborative monitoring sub-committee reported on the amount and quality of grass available. After the harvest in one area, the monitoring sub-committee identified other areas where grass was available and reported on its quality. Political problems put an end to the system, however. Resource management committee members were approached by the ward councillor, a cadre of the ruling party, with a proposal to use the funds raised by the resource management committee to sponsor a political party function. The committee members refused to do so, saying they had no power to spend the money without the approval of the community to which the money belonged. It is alleged that party officials led by the monitoring subcommittee chair, who was a staunch supporter and district chairperson of the ruling party, then set the Batanai grass area on fire. Following the incident, community members decided to dissolve the monitoring sub-committee.

In Gababe, in addition to monitoring the amount and quality of resources, the Forestry Commission and the communities began monitoring the performance of their resource management committee because of allegations about the embezzlement of funds. The communities demanded that the committee submit regular reports to constituents, rather than just to the Forestry Commission, providing details on its financial status and problems encountered. The Forestry Commission provided basic stationery so that committee members could submit monthly reports to both the department and the community, highlighting emerging issues. According to the Forestry Commission officer, this was a good way of monitoring RMCs and making sure they updated their communities on their progress (Mutimukuru et al. 2006).

\section{Post study developments}

To ensure that learning and collaboration processes would continue after the project ended, ACM team members helped train the Forestry Commission officer in the adaptive collaborative management approach. The officer also learned by participating and observing as he accompanied 
the ACM team during field work. The withdrawal process was gradual. At first, researchers offered considerable support to the Forestry Commission officer, but this support dwindled as the officer became more confident in organising and facilitating learning processes.

As a facilitator, the officer focussed less on resource use group learning processes, perhaps because of a lack of resources. The Forestry Commission suffered as a result of the declining economic situation, and for a time the officer did not even have a vehicle for travel. The resource user groups in all three areas stopped meeting, probably because no one was organising meetings. In Batanai, the community partner began cross-border trading in order to survive, and had no time to organise meetings. The Forestry Commission officer nevertheless continued to support broader learning processes by resource management committees around Mafungautsi (Box 2-5).

The Forestry Commission officer unfortunately passed away in October 2005. Although learning and collaboration activities in Batanai and Ndarire stopped at the time of his death, the Gababe committee continued organising meetings with local stakeholders (resource user groups, ordinary members of the community and traditional leaders) to plan and decide how to manage their resources. Local community members decided to use the money (ZWD 1,000,000 or USD 188.16) raised in July 2004 to build a two-roomed house for a teacher at the Gababe primary school. The committee purchased cement, local community members volunteered to mould bricks, and the builder was paid out of the resource management committee funds. The project was successful, and all community members in Gababe commended the committee, a better outcome than in previous years, when the committee had raised less money, failed to report to the community, and had been accused of embezzlement.

A new Forestry Commission officer was appointed for the Resource Sharing Project in January 2006. His main priority, in line with the Forestry Commission agenda of strengthening regulation of natural resources, was to evict the new settlers in Mafungautsi State Forest. It was partly because 


\section{Box 2-5. Learning processes facilitated by the Forestry Commission officer}

The Forestry Commission officer arranged for selected resource management committees to meet, share experiences and learn together. For instance, the Gwehava, Gababe, Sokwela, Batanai and Chemwiro Masawi committees met in August 2004 to familiarise new members with the constitution and terms of reference. Members took the opportunity to learn from one another and reflect on their individual performance.

Workshops preceding the grass cutting season became an annual activity on the Forestry Commission calendar and allowed resource management committees to reflect on the previous season, share their experiences and learn together. Issues discussed during these workshops included incentives for committee members, financial reporting, sustainable harvesting practices, possible projects that could receive funds generated by the resource management committees, and common problems and challenges, including developments in the country and their effects on resource management. Representatives from other projects, like the Communal Area Management Programme for Indigenous Resources (CAMPFIRE), came to share their experiences in dealing with their challenges.

Look and learn tours for district-level officers and local people were organised by the Forestry Commission to enhance joint learning processes. Previously, such tours were organised for the Forestry Commission officers alone; community members never participated. One trip was made to Nyagadza in February 2004 and another to Kana in May 2004.

of this that the officer failed to visit the study sites before he passed away, in October 2007.

The resource management committees in both Batanai and Gababe became less functional after 2006 as problems and conflicts intensified. In Gababe, for instance, even though several problems had been dealt with in 2004, and the committee had become more accountable and transparent to its community, things later deteriorated (Box 2-6).

Although things turned out badly in Mafungautsi after the death of the Forestry Commission officer, community members in some areas continued to use the knowledge and networks they had gained during the ACM project. For instance, during the meetings and workshops organised by 


\section{Box 2-6. Changes in the Gababe Resource Management Committee, 2005-2007}

In Gababe, after the resource management committee presented its 2004 financial report, most people were pleased with its performance and the status of resource management activities in their area. They gave the following reasons for the committee working so well:

- Collaboration among committee members.

- Members not practicing favouritism when allocating areas for harvesting resources.

- The committee having a strong and dedicated monitoring sub-committee.

- The committee having a good leader who was well educated and could understand all the financial transactions.

- Committee members being transparent and knowing what was going on.

- The committee working well with traditional leaders, who were now participating in resource management activities.

- The committee having agreed to use some of its funds to build a house; the committee's first significant project to benefit the community.

In October 2007 several problems arose. Local community members blamed the deterioration on a lack of support from the Forestry Commission after the death of its officer. Problems encountered in 2006 and 2007 included:

- Increased incidences of illegal tree cutting.

- Poachers taking game, particularly zebras, which they hunted for their skins; the resource management committee was advised by the Forestry Commission's forest protection unit not to take action because members were ill-equipped to do so, but the officials did not act either, saying they had no transport to patrol the forest.

- Local community members accusing resource management committee members of embezzling funds after the committee failed to report on its progress and finances.

- A higher frequency of forest fires attributed to the entry of poachers and the Forestry Commission's failure to open up lines to prevent the spread of fire in the forest.

- The committee losing one of its grass cutting areas, Ngondoma, to new settlers. As their numbers increased, they also occupied the grass cutting area for neighbouring Chemwiro Masawi. After the new settlers were arrested, Chief Njelele arranged for their release, and it was alleged that the chief owned about 30 acres of land in the forest on which the settlers worked for him for free.

- The resource management committee ceasing communications with local stakeholders; the general meetings with community members, training workshops, grass cutting workshops and the auditing of books all ceased. Asked why, a committee member said it was due to a lack of monitoring by the Forestry Commission.

The monitoring sub-committee was no longer functional. 
CIFOR, Gababe community members met their member of parliament (MP), who had never been to their area before. They approached him and their chief and asked for help with the following: (1) a resident Agricultural Research and Extension Services officer; (2) funds for building a local clinic; (3) Zimbabwe Republic Police services to reduce thefts and control juvenile delinquents; and (4) access to development projects. The MP (who belongs to ZANU-PF) helped them to get a resident agricultural extension officer, the services of a mobile clinic and police protection. The MP also approached Africare and Concern, two organisations already working in Gokwe, and got them to extend their services to Gababe. ${ }^{9}$

\section{Outcomes}

The ACM research project used social learning platforms to unlock local stakeholders' potential and strengthen their ability to collaborate and work together. This section discusses the major outcomes of ACM interventions from 1999 to 2005. The social learning and collaboration processes in the research sites appear to have ended after the Forestry Commission officer died and the Forestry Commission stopped performing its important facilitatory role in the project. The new officer appointed to take over the project also passed away before facilitating any processes in the study sites. This shows that the sustainability of joint learning processes depends on effective facilitation.

\section{Empowering local communities}

Through interventions aimed at building capacity and empowering local stakeholders (such as Training for Transformation), local people who were initially sceptical about the benefits of being involved in forest management began to take an active role, gained confidence in discussing their situation, and openly dealt with the many hidden conflicts. Interventions like visioning and scenarios also helped unlock people's potential to deal with obstacles (Nyirenda 2005). Facilitation, together with these other tools and approaches, contributed towards the empowerment of communities. 
The empowerment process often brought some unexpected results, however. As researchers focused on marginalised groups - women, the poor, the ethnic minorities - they paid little attention to the rich and powerful, who withdrew from the facilitated processes. Clearly facilitators must not ignore the rich and powerful while empowering the poor but should instead seek effective ways to keep them involved. How this can be achieved without reinforcing the status quo remains a challenge.

The effects of empowerment training cannot be entirely predicted. For instance, in Batanai, most resource users participating in the Training for Transformation workshop became actively involved in politics and supported the opposition party, making themselves vulnerable to violence at the hands of ruling party activists. Facilitators need to be aware that empowerment processes are complex and often lead to changes in other arenas as well.

\section{Emergence of new partnerships}

The initial phases of the ACM process were characterized by deep-seated animosity and mistrust between the Forestry Commission and communities, which made it very difficult for them to cooperate and work together. Relationships between these two parties improved after CIFOR identified and addressed the underlying problems, and a new partnership emerged. Much of the mistrust had been based on misconceptions. The Forestry Commission began to acknowledge that local people were knowledgeable and capable of solving their own problems. For example, the Batanai broom grass users devised their own solutions to their harvesting problem. Later, in a spirit of collaboration, the Forestry Commission officer helped market the new brooms on the Forestry Commission stand at the annual provincial agricultural show. In Ndarire, Forestry Commission officers also began to show interest in collaborating with local timber harvesters: they participated in a look and learn tour in Nyagadza and recommended to their head office that timber harvesting be made part of the resource sharing agreement. 


\section{Self-organisation for collective action}

Working with community partners and building their capacities helped enhance the local people's ability to organise themselves for the community's benefit. For example, the Gababe community members, using the skills they obtained from participating in the ACM project, organised themselves to obtain several essential social services from their member of parliament. The community partners in all the sites organised meetings for resource user groups, thereby creating opportunities for them to share their knowledge and experiences, reflect on them and learn together. These meetings took place even when researchers were not present.

The major challenge in Mafungautsi, however, was creating incentives for community partners to continue their work - necessary for the institutionalisation of the learning and collaboration processes - after the project ended. The Forestry Commission officer, who took over the facilitation of the social learning and collaboration processes, received an allowance during the project, and one wonders whether he would have continued once the financial incentive had gone. One possible solution is changing the Forestry Commission incentive system to include processes rather than just quantifiable outcomes.

\section{Ability to adapt}

The conscious social learning processes facilitated in Mafungautsi enhanced stakeholders' adaptive capacity (Mutimukuru et al. 2005). In Batanai, when resource users had the opportunity to reflect critically on their situation and the condition of their grass resource, they came up with mechanisms for sustaining the resource as well as improving their incomes. Stakeholders in Gababe developed a system of monitoring broom grass plots to ensure equitable distribution and to ascertain the amount of grass harvested each year.

\section{High transaction costs}

During the ACM research project, local community members began, for the first time, to engage in managing their forest resources and participate 
in decision-making processes. People spent considerable time in meetings, discussion and reflection sessions and workshops, which were scheduled for the off-season of the agricultural year. However, harvesting of forestry resources, mainly grasses, takes place during this same time of year, and these resources are a major source of income. This may explain why some resource users did not attend the meetings.

\section{Value addition and alternative markets}

The forest products communities were concentrating on, like broom grass, are of low economic value. By adding value, people managed to increase their incomes. For instance, Batanai's decorated brooms sold at a much higher price than the undecorated brooms. Value addition to forest products like timber would have brought even more income, which is why in Ndarire, the Forestry Commission officer and the resource users sought to have timber included under the Resource Sharing Project.

\section{Improved knowledge}

The collaborative monitoring systems helped Mafungautsi stakeholders better understand their resources. Previously, information gathered by resource users would be made available to a few stakeholders, but with collaborative monitoring, a broad range of people gained knowledge. In Batanai, for example, the monitoring sub-committee informed resource users about additional sources of grass as well as its quality. The context study exercise also benefited both locals and outsiders. The resource user groups generated knowledge for improving their own management strategies. And the community partners documented information on behalf of local participants and retained this material within the communities.

\section{Discussion}

This section returns to the three questions raised at the beginning: Does adaptive collaborative management lead to improvements in both the 
resource condition and human lives, and if so, under what conditions? What challenges do those using the ACM approach face, especially in politically volatile situations? And finally, what lessons can be drawn from Mafungautsi for enhancing the participation of local communities in the management of forest resources?

\section{Improvements in resource condition and human lives}

When the ACM approach was introduced in three sites in Mafungautsi, it was hoped that the Forestry Commission officer would extend the approach to the remaining 11 sites. As that did not happen, the question as to whether the whole forest can be managed sustainably remains unanswered. In the three study sites, resource management systems deteriorated following the death of the Forestry Commission officer, and in 2006 and 2007, resource users said that forest resources were subject to increased forest fires, timber harvesting and poaching. The volatile situation in the country also exacerbated conditions, as it resulted in an increase in the mobility of resource users and an increase in the number of new settlers in the forest. This discussion will therefore focus on 1999-2005, when ACM practitioners, the researchers and later the Forestry Commission officer were active in facilitating learning and collaboration processes.

Before the ACM research project in Mafungautsi began, learning processes were spontaneous rather than conscious, and there was little sharing of lessons learned by stakeholders. The ACM project helped make learning processes deliberate and conscious and encouraged social learning. Stakeholders' enhanced ability to adapt permitted them to improve both resource conditions and their well-being. For instance, in Batanai, the ACM researchers' report on the number of trees cut during honey harvesting surprised local people and prompted them to devise ways to sustain the tree resource. The beekeeping projects they initiated both generated income and reduced the cutting of trees. Another example is the Batanai broom grass case: after social learning platforms were created, stakeholders came up with ways to sustain the resource and increase their income from broom making (Of course, the new, more durable brooms 
last longer and might ultimately reduce demand, and if that happens, the resource users will need to deal with the challenge).

The benefits local resource users derived from their management initiatives gave them incentives to learn more and improve their management systems. By increasing their social and human capitals, they were able to increase their incomes. As the resources were important for their livelihoods, they had no need for management incentives from outside.

\section{Challenges to the ACM approach}

The ACM researchers faced several challenges.

» Focus of intervention. The ACM researchers' goal was sustainable forest management with an emphasis on non-timber forest products, as outlined in the agreements between the Forestry Commission and local communities (Forestry Commission 1997). Some community members, however, wanted them to address the land issue. Ultimately, the land issue threatened the resource management efforts as people continued to settle in the forest.

» Role of facilitators. ACM practitioners need to become learners alongside the local people, and take on the role of facilitation. Facilitation however, is an art and practitioners may not possess the skills naturally. This requires investment in building ACM practitioners' facilitation skills.

"Incentives for local stakeholders to continue facilitating learning and collaboration processes. Incentive systems for most organisations are based on measurable, quantifiable outcomes and not processes. If one is to use the ACM approach that focuses on processes, incentive systems also need to reward the facilitation of good processes.

» Lack of capacity by local stakeholders. ACM encourages active participation by all stakeholders, and this requires investment in capacity building for all stakeholders.

» Political turmoil and economic problems. In volatile political environments, resource users become mobile, thereby affecting the continuity of social learning processes. Also in periods of 
hyperinflation, the benefits from resource management activities are eroded.

»Startup costs. The high initial investments in time and resources required to set up the basic conditions for participatory action research can deter people from adopting the ACM approach.

»Uncertain funding. The process-based nature of the ACM approach requires a long-term commitment, but donor funding may expire before a project can demonstrate its value.

\section{Lessons learned for enhancing participation of local communities}

One lesson from Mafungautsi is that focusing on small groups of resource users not only saves costs but also enables fast learning because members have strong interests, knowledge, skills and experience in their particular resource. The user groups in Mafungautsi could define their resource management problems and then identify solutions and take action. Facilitation merely released the local people's latent potential, and learning took place both horizontally and vertically.

Working with groups can be slow if new members need to be updated before they can participate. On the other hand, if a group is not flexible or open to new members, working with it can worsen existing power differentials. Another challenge is that community members who refuse to join the groups can undermine worthy initiatives. Clearly defined boundaries and by-laws are therefore important (Ostrom et al. 1993; Murphree 1993).

In relatively stable socioeconomic environments, it is possible to enhance conscious multi-scale and multi-directional learning processes. Conflicts over the management and utilization of natural resources are bound to arise, and it is important to establish mechanisms to resolve them. In unstable socioeconomic and political conditions, as in Mafungautsi, preexisting conflicts had to be resolved before people could come up with a shared vision for the future and engage in effective social learning processes. Use of the ACM approach is unlikely to produce positive results 
when people are mobile and financial benefits are eroded by inflation. In politically volatile situations, resource users may also be banned from organising learning opportunities as in Batanai in 2002.

Investing in capacity building is crucial for the success of people-centred approaches and should be done both at the outset and as the need arises during the project. In Mafungautsi, the Forestry Commission officer's training in using the ACM approach and the community members' participation in workshops gave the parties the skills they needed.

Finally, facilitation plays a central role in the sustainability of joint learning and collaboration. The learning processes stopped when the ACM project ended because the community partners did not have incentives and lacked leadership from the Forestry Commission, the owner of the forest resource. Social learning processes for the broader Mafungautsi community members (such as the workshops organised just before the grass cutting season) were also impeded by the death of the Forestry Commission officer. Continuity in facilitation is therefore crucial for the sustainability of learning and collaboration processes.

\section{Conclusion}

This chapter has described how the ACM team, working in the deteriorating socioeconomic and political conditions in Zimbabwe, facilitated processes aimed at enhancing improvements in resource conditions and the lives of forest-dependent communities. Team members worked under the watchful eyes of local politicians. The Forestry Commission also suffered from the deteriorating economic situation, and its officer lacked basic resources to carry out his work.

Despite these challenges, the ACM project did have several positive outcomes during its early stages: the empowerment of local community members, the emergence of genuine partnerships, improvements in 
stakeholders' self-organisation towards collective action, enhancement of stakeholders' ability to adapt through joint learning, higher incomes, adoption of sustainable harvesting methods, improved knowledge about resources through collaborative monitoring and acquisition of knowledge through information sharing platforms like workshops. Negative outcomes included high transaction costs in time spent attending resource management meetings and workshops. Ultimately, the social learning and collaborative management processes were not sustained, mainly because their facilitation was discontinued.

The following conclusions can be drawn from the ACM research work in Mafungautsi:

» Investment in capacity building is important for enhancing participation in people-centred approaches. Capacity building should be done both at the outset and as the need arises during the project.

» Using the ACM approach in politically volatile situations will not yield lasting positive change. Under such conditions, it may not be possible to organise opportunities for resource users to meet, share experiences and learn together.

» In stable socioeconomic and political environments, the ACM approach has potential for enhancing the lives of local people and the status of natural resources. Under these conditions, making joint learning processes deliberate and conscious enhances adaptiveness in resource management.

» The role of facilitation is crucial at all times for the sustainability of learning and collaboration processes. 


\section{Endnotes}

${ }^{1}$ The following assumptions underlie the ACM approach: (1) forest-dependent people are part of complex and dynamic forest and human systems that are constantly changing, making predictions impossible and surprises inevitable; (2) forest-dependent people have the capacity to act, have agency and possess invaluable knowledge about their systems, and it is therefore important for them to participate in the management of their natural resources; and (3) resource management efforts that ignore the issue of equity are doomed to fail because inequity results in conflict and violence (Colfer 2005).

${ }^{2}$ The community partners and some community members from the research sites also took part in participatory modelling as a way of exploring their visions and ideas; this is reported more fully in Vanclay et al. (2006).

${ }^{3}$ At the time of the report back meeting, seven villages had moved back into Zanda plateau; the Forestry Commission and other government agencies acknowledged this but had done nothing about it because of the political nature of the issue.

${ }^{4}$ Training for Transformation's six principles are (1) no education is neutral, since it can either enslave you or liberate you; (2) education should be relevant; (3) education should promote dialogue; (4) education should encourage a process of reflection and learning; (5) education should promote radical transformation; and (6) people should be critical when trying to solve problems and searching for solutions.

${ }^{5}$ The act limits people's rights to freedom of expression. It prohibits speech that is likely to promote feelings of hostility towards state institutions and the president (Human Rights Watch 2003). Under this act, anyone organising a public meeting must report to the police four days before the meeting and obtain clearance.

${ }^{6}$ Visions are defined as stories of what might be (Wollenberg et al. 2000). Visioning encourages critical thinking and evokes and communicates people's ambitions, plans and perceptions of change; it helps them decide how to adapt to changing circumstances and achieve their desired goals. 
${ }^{7}$ One of these two women currently holds several leadership positions (she sits on a committee created by the Ministry of Health and Child Welfare that provides porridge to preschool children). Asked about this, she smiled and told us, 'Zvakatanga pandakawana ruzivo kubva kumaworkshops enyu veCIFOR ('It started after I learned several lessons by participating in the CIFOR workshops'). This woman avers that participating in the ACM research helped her uncover and realise her potential.

${ }^{8}$ Decorated brooms were selling at ZWD 1500 (USD 1.84) each in Harare. Mrs Sibanda, however, preferred to sell undecorated brooms because they sold faster, normally at wholesale prices to bulk buyers who later decorated the brooms for resale.

${ }^{9}$ Concern started working in Gababe in 2005 and gives people maize grain, cooking oil, beans and porridge. About 90 percent of the people benefit from this project. Africare works with people who were left out of the Concern project. The organisation gives people seed, peanut butter pressing machines, oil pressing machines, and cooking oil. They also teach people how to process soya beans and prepare them into various foods (milk, bread). The Africare group is led by a former member of the beekeeping resource user group. 


\section{References}

Allen, W. 2001 Working together for environmental management: The role of information sharing and collaborative learning. PhD thesis, Development Studies, Massey University, New Zealand.

Armitage, D., Berkes, F. and Doubleday, N. (eds.) 2007 Adaptive comanagement: Collaboration, learning, and multi-level governance. University of British Columbia Press, Vancouver.

Borrini-Feyerabend, G. 1996 Collaborative management of protected areas: Tailoring the approach to the context. Gland, Switzerland.

Bradley, P.N. and McNamara, K. (eds.) 1993 Living with trees: Policies for forestry management in Zimbabwe. Technical Paper 210. World Bank, Washington, D.C.

Bray, D.B., Merino-Perez, L. and Barry, D. (eds.) 2005 The community forests of Mexico: Managing for sustainable Landscapes. University of Texas Press, Austin.

Brechin, S.R., Wilsushen, P., Fortwangler, C.L. and West, P.C. 2002 Beyond the square wheel: Toward a more comprehensive understanding of biodiversity conservation as social and political process. Society and Natural Resources, 15:1, 41-64.

Buck, L.E., Wollenberg, E. and Edmunds, D. 2001 Social learning in the collaborative management of community forests: Lessons from the field. In: Wollenberg, E., Edmunds, D., Buck, L., Fox, J. and Brodt, S. (eds.) 2001 Social learning in community forests. Center for International Forestry Research and East-West Centre, Bogor.

Childes, S.L. and Walker, B.H. 1987 Ecology and dynamics of woody vegetation on the Kalahari sands in Hwange National Park, Zimbabwe. Vegetatio 72: 111-128.

Colfer, C.J.P. 2005 The complex forest: Communities, uncertainty, and adaptive collaborative management. Center for International Forestry Research and Resources for the Future Press, Washington, D.C.

Edmunds, D. and Wollenburg, E. (eds.) 2003 Local forest management: The impact of devolution policies. Earthscan, London. 
Fisher, R. 1995 Collaborative management of forests for conservation and development. IUCN and World Wildlife Fund for Nature, Gland, Switzerland.

Forestry Commission 1997 Mafungabusi Resource Sharing National Seminar, Kadoma Ranch Motel: 9-11 April. Forestry Commission, Harare.

Friere, P. 1970 Pedagogy of the oppressed. New York. Herder and Herder.

Geldenhuys, C.J. 1977 The effect of different regimes of annual burning on two woodland communities in Kavango. South African Forestry Journal 103: 32-42.

Greenwood, D.J. and Levin, M. 1998 Introduction to action research: Social research for social change. Sage Publications, London.

Guerrero, J.L. 1995 Research paradigm shift: Participatory action research. Working Paper No. 2, June. Rehabilitation Research and Training Centre of the Pacific. Interwork Institute, San Diego State University, California. http://interwork.sdsu.edu/projects/rrtcp/pubs/par.html

Hope, A. and Timmel, S. 1995 Training for transformation: A handbook for community workers (rev. ed.), Books I-III. Mambo Press, Gweru, Zimbabwe.

Human Rights Watch 2002 Fast track land reform in Zimbabwe. 14(1A). March.

Human Rights Watch 2003 Under the shadow: Civil and political rights in Zimbabwe. Accessed at http://hrw.org/backgrounder/africal zimbabwe060603.htm on 30 May 2007.

McDougall, C., Kaski ACM team, NewERA ACM team and Forest Action 2002 Planning for the sustainability of forests through adaptive co-management: Nepal country report. ACM Project/MoFSC Internal Research Report. Center for International Forestry Research, Bogor.

Matose, F. 1994 Local people's uses and perceptions of forest resources: An analysis of a state property regime in Zimbabwe. MS thesis. University of Alberta, Canada. 
1997 Conflicts around forest reserves in Zimbabwe: What prospects for community management? IDS Bulletin 28(4): 69-78.

2002 Local people and reserved forests in Zimbabwe: What prospects for co-management? PhD dissertation. Development Studies, University of Sussex, Brighton, U.K.

Matzke, G.E. and Mazambani, D. 1993 Resource sharing schemes for state owned land in Zimbabwe: A discussion of conceptual issues needing consideration in the development and planning of co-management regimes. CASS Occasional Paper. Centre for Applied Social Sciences, University of Zimbabwe.

Murphree, M.W 1993 Communities as resource management institutions. Gatekeeper series No. 36. International Institute for Environment and Development, London.

Murwira, K., Wedgwood, H., Watson, C. and Win, E.J. 2000 Beating hunger, the Chivi experience: A community-based approach to food security in Zimbabwe. ITDG, Harare, Zimbabwe.

Mutimukuru, T., Kozanayi, W. and Nyirenda, R. 2006 Catalysing collaborative monitoring processes in joint forest management situations: The Mafungautsi Forest case, Zimbabwe. Society and Natural Resources 9(3): 209-224

Mutimukuru, T., Nyirenda, R. and Matose, F. 2005 Learning amongst ourselves. Towards adaptiveness by stakeholders in forest management through social learning in Mafungautsi. In: Colfer, C. (ed.) The equitable forest: Diversity, community and resource management. Resources for the Future Press, Washington, D.C.

Nhira, C., Baker, S., Gondo, P., Mangono, J.J. and Marunda, C. 1998 Contesting inequity in access to forests: Zimbabwe country study. Policy that works for forests and people. Center for Applied Social Sciences, and Forestry Commission, Harare, and International Institute of Environment and Development, London.

Nyirenda, R. 2005 Locating the energy for change: Using visioning to improve local people's involvement in co-management of forests in Mafungautsi State Forest, Zimbabwe. MS thesis. Centre for Development Studies, University of Wales, Swansea, U.K. 
Ostrom, E., Schroeder, L., and Wynne, S. 1993 Institutional incentives and sustainable development: Infrastructure policies in perspective. Westview Press, Boulder, Colorado.

Piearce, G.D. and Gumbo, D. 1993 Ecology and the management of indigenous forests: Proceedings of an international symposium held in Victoria Falls, Zimbabwe, July 1992. Forestry Commission and SAREC, Harare.

Pimbert, M.P. and Pretty, J. 1995 Parks, people and professionals: Putting 'participation in protected area management. Discussion Paper 57. United Nations Research Institute for Social Development, Geneva.

Plummer, R. and Armitage, D.R. 2007 Charting the new territory of adaptive co-management: A Delphi study. Ecology and Society 12(2): 10. http://www.ecologyandsociety.org/vol12/iss2/art10/

Prabhu, R. 2003 Developing collaborative monitoring for adaptive comanagement of tropical African forests. Final Technical Report for January 1, 2000-December 31, 2002. Center for International Forestry Research, Harare.

Prabhu, R., McDougall, C. and Fisher, R. 2007 Adaptive collaborative management: A conceptual model. In: Fisher, R., Prabhu, R. and McDougall, C. (eds.) Adaptive collaborative management of community forests in Asia: Experiences from Nepal, Indonesia and the Philippines. Center for International Forestry Research, Bogor.

Ruitenbeek, H.J. and Cartier, C. 2001 The invisible wand: Adaptive comanagement as an emergent strategy in complex bio-economic systems. Occasional Paper No. 34. Center for International Forestry Research, Bogor.

Selener, D. 1997 Participatory Action Research and Social Change. Cornell Participatory Action Research Network. Cornell University, Ithaca, New York.

Timberlake, J.R., Nobanda, N. and Mapaure, I. 1993 Vegetation survey of the communal lands - north and west Zimbabwe. Kirkia 14: $171-270$. 
Vanclay, J., Prabhu, R. and Sinclair, F. 2006 Realising community futures: A practical guide to harnessing natural resources. Earthscan, London.

Vermeulen, S.J. 1994 Consumption, harvesting and abundance of wood along the boundary between Mafungautsi and Gokwe Communal Area, Zimbabwe. MS thesis. University of Zimbabwe.

Wild, H. and Barbosa, L.A.G. 1967 Vegetation map of the flora Zambesiaca area. Collins, Harare.

Wilshusen, P.R., Brechin, S.R., Fortwrangler, C.L. and West, P.C. 2002 Reinventing the square wheel: Critique of a resurgent 'protection paradigm' in international biodiversity conservation. Society and Natural Resources 15:17-40.

Wollenberg, E., Edmunds, D. and Anderson, J. 2000 Anticipating change: Scenarios as a tool for adaptive forest management: A guide. Center for International Forestry Research, Bogor. 
A collector well in the Chivi communal area (Photo by Bruce Campbell)

Chapter 3

Action planning and adaptive management of natural resources in semiarid environments:

Experiences from Chivi District, Zimbabwe

Nontokozo Nemarundwe

Manyewu Mutamba 
daptive management is one of many community-based resource
management approaches that have been tested in Southern Africa during the past two decades. Adaptive management is based on experiential learning and decision making, buttressed by active monitoring and feedback from the outcomes of decisions, and applied to the management of complex systems (Jiggins and Röling 1999). It is concerned with relations between people and their environment; in particular, the ecological processes on which human existence depends.

Jiggins and Röling (1999) identify three benefits of using the adaptive management approach. The first is the potential to avert crises in conditions of uncertainty and surprise by increasing society's capacity to adapt and "roll with the punches". The second is providing a social steering instrument, complementary to regulatory and normative measures, that strengthens broad-scale multi-stakeholder engagement in environmental management. Lastly, the approach offers a way in which universalised abstractions of science and the technologies that flow from science can be coupled with local people's knowledge of reality as they experience it, and set in context.

Management is said to be adaptive when it acknowledges that the resources being managed are always changing and that surprises are inevitable. Active social learning, one of the keys to adaptive management, is important in dealing with uncertainty. Another key is the grounding of institutions in local ecological knowledge. External development organisations and research-based interventions need to take cognisance of these institutions and build on existing local knowledge. A third key is monitoring, which should be participatory wherever possible. The information collected and shared during the monitoring process is used to interpret ecological change, make comparisons between past and present states, as well as to predict future changes and thus improve decision making and management plans. In recent years, in most countries in Southern Africa, adaptive management approaches have emphasised the use of participatory approaches in community-based management (Barrow et al. 2002). 
Throughout Southern Africa there has been a shift towards participatory approaches in development - in both theory and practice - to ensure empowerment of communities to manage natural resources (Shackleton and Campbell 2001; Critchley and Turner 1996). The practical projects have taken an integrated, multi-sectoral approach to developing resource management plans that can address both biophysical and socioeconomic factors and be adaptive to changing situations (Campbell and Sayer 2003). Unfortunately, few of these projects can be counted as successes. This chapter brings to the fore some of the challenges and constraints to community-based natural resources management in arid environments, using experience in action research processes. It illustrates the need for adaptive rather than prescriptive policies in changing circumstances.

We begin by describing first the context and the study sites and then the research methods. The subsequent section discusses the learning experiences from Chivi District in Zimbabwe. Two cases are used as sources for lessons on action planning and adaptive management; namely, the use of scenario building to forge 'new' institutional arrangements, and the application of action research to indigenous tree planting and management. The two final sections distil lessons learned and offer concluding thoughts.

\section{Historical context}

Current challenges and constraints in Chivi District have their roots in events at the turn of the 20th century. This period was characterised by colonisation of what was then Southern Rhodesia ${ }^{1}$, the first colonial settlers having arrived between 1893 and 1896. During the early colonial period, land was apportioned along racial lines, with colonial settlers being allocated the best land (termed commercial farming areas), forcing the bulk of the increasingly marginalised and impoverished black community into heavily populated communal areas. The Land Apportionment Act of 1930 excluded Africans from the half of the country that contained the best farmland (Dzingirai 1998), effectively handing the fertile, high rainfall areas to whites and pushing Africans to less agriculturally productive lands. 
The inequitable distribution of land largely accounts for Zimbabwe's war of independence and continues to be an important factor in Zimbabwean politics. This pattern of land distribution remained in place until the post-2000, 'fast-track' resettlement programme, which has created general anarchy in the former commercial farming areas. When the fasttrack resettlement programme began, some residents from Mutangi, and particularly Romwe, moved to the newly resettled areas but did not relinquish their old homesteads because of uncertainty about the ultimate outcome. Thus the pressure on land in the study sites has not been relieved by the resettlement programme.

Settlement in Chivi District was a result of the forced relocation of black people in the 1950s from the Midlands Province when colonial land policies, such as the Land Apportionment Act of 1930, were enforced (Dzingirai 1998). At that time, land grants were being made to white soldiers who had served in the Second World War, and the original inhabitants of the land were forced to move to areas like Chivi. There was some limited redistribution of land in the 1980s, but this did little to relieve high population densities. Even in the post-2000 period, the impact of resettlement on population densities in Chivi has been negligible (Nemarundwe, 2003). As of 2008, nothing much had changed in the study sites: the people who moved to the newly resettled areas are still holding on to their land in the study sites (Kozanayi, pers. comm. May 2008).

\section{Selection of study sites}

For three years (1999-2001) researchers from the Institute of Environmental Studies (University of Zimbabwe), development workers from a non-governmental organisation (CARE International), community members and district officials explored the role of an integrated approach to managing catchments in semiarid areas of Zimbabwe to alleviate poverty. To obtain an in-depth understanding of participatory processes, researchers decided to focus on just two study sites in the Chivi District of Masvingo Province, southeastern Zimbabwe. The Chivi communal area covers 3,534 square kilometres (Campbell et al. 2002). 
One site, Romwe ( $\left.20^{\circ} 45^{\prime} \mathrm{S}, 30^{\circ} 46^{\prime} \mathrm{E}\right)$, was selected because it had been the subject of relevant research done mainly by the Centre for Ecology and Hydrology (formerly the Institute of Hydrology, a U.K. research organisation). The other site, Mutangi (20 $\left.15^{\circ} \mathrm{S}, 30^{\circ} 30^{\prime} \mathrm{E}\right)$, was selected for contrast: it had greater levels of land degradation, lower rainfall and, possibly, a poorer community. The majority of the communal areas in Zimbabwe tend to have similar conditions to Chivi district: poor and erratic rainfall, poor agricultural soils and population pressure (Jennings and Huggins 1935). Both Romwe and Mutangi are headwater catchments of the Runde River and lie $70 \mathrm{~km}$ apart as the crow flies (Figure 3-1).

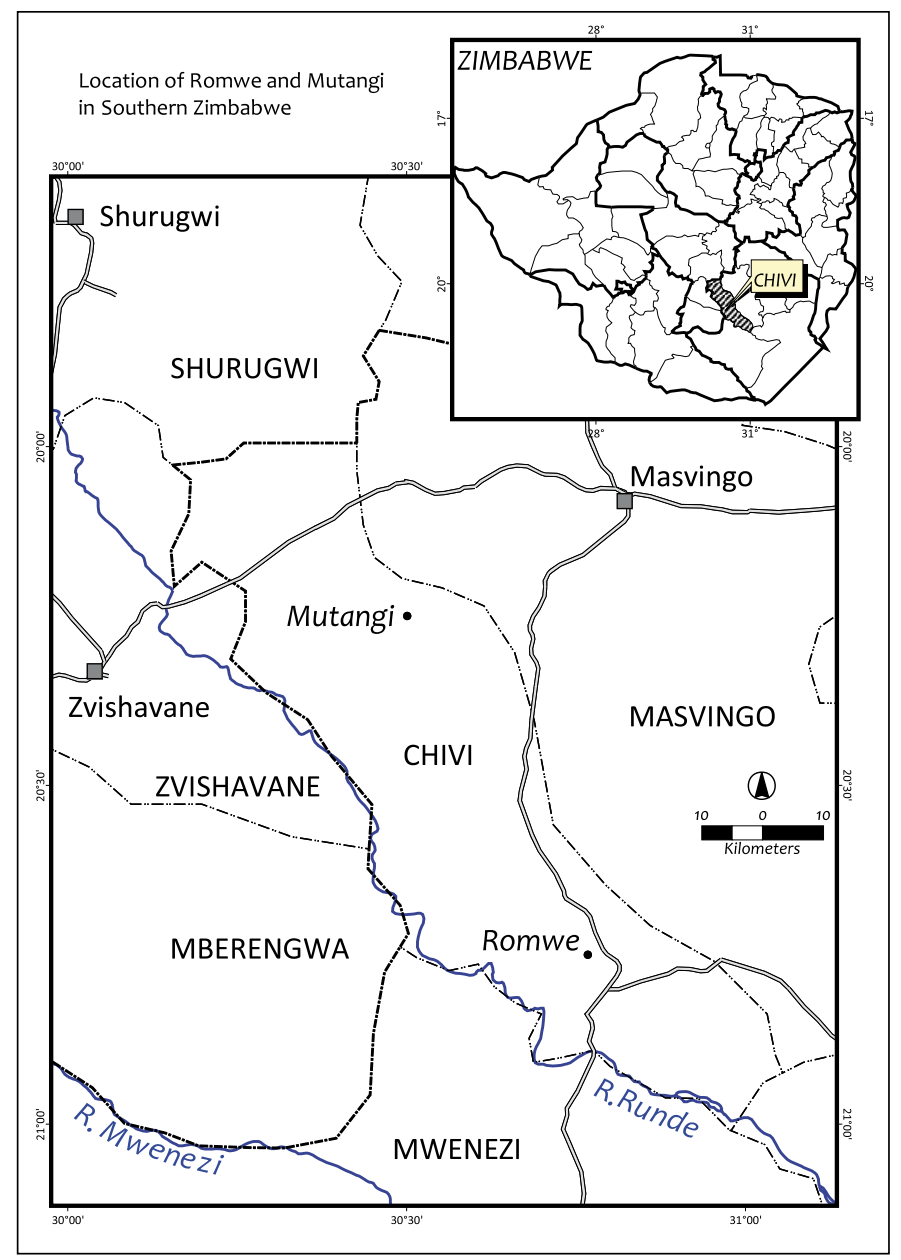

Figure 3-1. Romwe and Mutangi catchments, Chivi District 
The Romwe catchment, with an area of $4.6 \mathrm{~km}^{2}$, lies $86 \mathrm{~km}$ south of Masvingo, the provincial capital, and is close to Ngundu Business Centre $\left(20^{\circ} 45^{\prime} \mathrm{S}, 30^{\circ} 46^{\prime} \mathrm{E}\right)$. Gentle slopes along the valley floor are encircled by relatively steep rocky hills, although there are three saddles between the hills where the catchment is less clearly defined. The stream in the catchment is a tributary of the Runde River. The primary catchment is the Chidiso collector well ${ }^{2}$, used for small-scale irrigation of community gardens; there are a total of 32 wells and two boreholes. The population of Romwe is approximately 256 people, comprising 32 households in three traditional villages. Historically, 10 traditional villages have had informal arrangements for sharing resources in the catchment area, including water, pasture and forest products. There are two community gardens, one developed by the Institute of Hydrology, and a second established with the help of CARE International.

The Mutangi catchment, comprising $5.7 \mathrm{~km}^{2}$, lies close to Chivi District Centre $\left(20^{\circ} 15^{\prime} \mathrm{S}, 30^{\circ} 30^{\prime} \mathrm{E}\right)$. The topography in Mutangi is gently sloping, and the catchment is drained by an ephemeral stream that branches into four tributaries halfway to the upper reaches of the catchment. The long-term rainfall average at Chivi, $14 \mathrm{~km}$ east of the catchment, is 550 $\mathrm{mm}$ per annum. Mutangi has both surface and ground water, provided by the Mutangi dam, three boreholes and 16 wells, used for small-scale irrigation. The population of the catchment numbers roughly 160 , with 27 households. There is one community garden, whose establishment was facilitated by CARE International.

\section{Research and facilitation methods}

Information was collected through a wide variety of techniques, including literature reviews, participatory action research (PAR) and informal interviews. Literature reviews were used to place the case studies within the context of local, district, national, and natural resource governance. The three main adaptive management approaches undertaken as part of PAR processes included participatory rural appraisal (PRA), Training for Transformation ('T for T') and scenario building (which includes visioning). 
PRA methods, tools and techniques were used to generate understanding of the local context and included historical trends analysis, resource and institutional analysis, group discussions and key informant interviews that provided in-depth understanding of the local context and resource management-related issues and challenges. Training for Transformation was conducted in August-September 2000 for representatives from both Romwe and Mutangi catchments. The aim of the training was to strengthen community capacity by raising critical consciousness of common concerns to the participants. Training for Transformation has been used to effect change in a community, increase people's willingness to act and promote accountability, responsibility and trust among community leaders. The training workshop was conducted in the local language, Shona, to ensure active participation by all participants. The training itself was participatory and was done through group discussions, case studies, picture codes, 'ice breakers', 'energisers' and brainstorming. Because women tend to be reserved or withdrawn in the presence of men in the local culture, facilitators generally separated men and women at certain points so that women could freely express their opinions. Follow up interviews were conducted after large community meetings to get a better understanding of the issues raised.

Two researchers lived in the Romwe area; a third was resident in Mutangi for more than two years and gained a clearer picture of the context by observing the participants' lives and work and by participating in community life. One of the two researchers in Romwe was a master's degree candidate, and the other was a field assistant employed by the University of Zimbabwe. The researcher in Mutangi was also a field assistant employed by the University of Zimbabwe. These three researchers spent at least 10 months a year residing in their villages to enrich their understanding of the relationship between local livelihoods and natural resources management. The researchers also gained deeper insights into the lives of the communities by participating with them in action learning initiatives on tree and woodland management, micro credit, soil and water conservation, garden expansion and new governance arrangements (Mandondo et al. 2001; Nemarundwe 2001; Gerhardt \& Nemarundwe, 
2006): these activities provided the material for adaptive management initiatives. By participating in the learning process, researchers gained insight into why some things worked while others did not. As part of the learning process, farmers and researchers participated in numerous look and learn visits, farm demonstrations, field days, research feedback meetings, and courses in marketing, hydrology and leadership.

At each study site, two initiatives were pursued:

»Crafting participatory resource governance arrangements through scenario building and visioning exercises;

»Action research on indigenous tree planting and management.

\section{Case 1: Creating 'new' institutional arrangements}

The first case study involved crafting participatory resource governance arrangements. This was done using scenario building and visioning exercises, building on experiences by Wollenberg et al. (2000) in the use of these tools for future planning. The resource regulation systems crafted under the colonial administration and inherited by the Independence government were highly centralized and largely top-down. The regulatory regime was mostly ineffectual, in part because there was little capacity to enforce the legislation. The 1970s and 1980s saw a wave of new approaches that emphasised the participation of local communities in development initiatives in general and natural resources management in particular, with efforts to decentralise management from central government to local government authorities, with the aim that local governments would further devolve management authority to local communities.

In Zimbabwe, the rural district councils were given the legal mandate to manage natural resources. Although the district governments are closer to the people than central government, very little changed in terms of actual empowerment and participation of local communities in decision making 
(Campbell et al. 2000). Rural district councils are guided by national legislation in developing environmental by-laws, regulating use of grazing land and prescribing conservation measures in their jurisdictions. Some of the national laws that guide the district councils include the Rural District Council Act (1988), Communal Lands Act (1982, amended in 1985), Communal Lands and Forestry Produce Act (1987), Forest Act (1982) and the Water Act (1998). Recent studies have blamed the lack of devolution of management authority on the upward accountability of local representatives or authorities (as opposed to downward accountability, to their local constituencies; Ribot 1999; Mandondo 2001; Matondi 2001); the bureaucratic impulse by local governments to retain authority rather than further devolve it to local communities (Murphree 1993); and a lack of trust that local communities will make appropriate or 'right' decisions.

Mandondo (2001) and Ribot (1999) have also argued that management authority has not been devolved to local communities because the process of decentralisation has been supply led rather than demand driven, which because of the bureaucratic impulse to retain power has resulted in 'cosmetic' empowerment. Nemarundwe (2003; 2004) attributes the problem to the multiplicity of institutional structures and jurisdictional 'fuzziness', which makes it unclear to which institutions management authority should be devolved. The effect is that communities have largely remained marginalised from the management of resources, even those in the areas where they live. In Romwe and Mutangi, various stakeholders: community members, district authorities, non-governmental organisation facilitators and researchers sought to enhance community inclusion and participation in adaptively managing their woodlands and water resources through visioning and scenario building.

\section{Planning for action}

Prior research on institutional arrangements for managing common pool resources, such as woodlands and water, had revealed a problem with the district government authority and village-level resource management institutions: there was little or no synergy between the multiple institutional structures, and despite an array of district council by-laws, enforcement 
mechanisms were ineffective (Mandondo 2001; Siziba et al. 2000). For example, the Rural District Councils Act of 1988 vests councils with the authority to enact land use planning and conservation and other by-laws, which become legally binding for areas under their control. Conservation by-laws include restrictions on use of wetlands for settlement or agricultural production, prevention of forest fires and restrictions on commercialisation of forest products without approval from the councils.

Enforcement of the by-laws is often complicated by overlapping mandates with other government institutions, such as the Department of Natural Resources and the agricultural extension department. Yet traditional rules and norms already existed that could become the framework for governing common pool resource use. Thus the Institute of Environmental Studies and its partners saw the need to facilitate a participatory resource management approach that would be more inclusive, and they decided to bring the stakeholders together to craft more workable by-laws. Facilitators included representatives from the Institute of Environmental Studies, CARE International, the Center for International Forestry Research, the Centre for Ecology and Hydrology, the Forestry Commission, the Department of Natural Resources, the agricultural extension department and to a smaller extent the University of Uppsala's Department of Plant Ecology ${ }^{3}$.

\section{Scenario building}

First, separate visioning exercises were facilitated with community members in Romwe and Mutangi. The objective of scenario building at the community level was to get local people's views on approaches for managing common pool natural resources and addressing current challenges. These exercises were held first so as to build community representatives' confidence in articulating their views amongst district officials.

As part of the preparation, an all-day community-wide meeting was held in each of the two catchments. Attendance averaged 100 participants. To make the facilitation process more manageable, participants were divided into three groups: women, older men and younger men. As a follow up to each meeting, three smaller and shorter meetings were facilitated in the 
catchments to further develop the community vision, prepare presentations and select presenters for the district meeting. In both catchments role plays were used to allow more sensitive views to be expressed. For example, the role plays highlighted local power dynamics that would not normally be discussed openly. The role plays also revealed resource governance issues, such as fines for offenders and use of the revenue. Cases of favouritism and bias by local leaders in enforcing resource use rules were also portrayed in the role plays.

At the district level, the main objective of the scenario building was to solicit the views of the district councillors on possible pathways to inclusive resource governance arrangements, particularly their scope to devolve resource management to lower levels. The representatives from the Romwe and Mutangi catchments presented the visions developed in the village meetings. Participants from both the local community and the district council developed their visions of the future as a first step towards redefining current development pathways. The visions were organised around natural resource governance systems, emphasising natural resource use, conservation and reform of governance systems. Group discussions brought up the need to devolve resource management power from the district council to local communities. The visions highlighted a shift from the council's command and control mode of operation to greater transparency and local responsibility, where the council would become primarily a facilitator, supportive of community initiatives. To complement the discussions, researchers presented two case studies of successful devolution in forest management in Tanzania.

\section{Outcomes}

Both the community and the district-level meetings generated much enthusiasm from all participants, who expressed the hope that there would be more such interactive meetings. The district meeting was a good platform, since most of the village representatives had never before had a chance to discuss resource governance issues with the rural district council authorities. The process of developing visions at the district level began with five subgroups. Four comprised a random mixture of individuals, and 
each covered a different topic: water, woodlands, livestock and grazing, and enforcement mechanisms. The fifth subgroup comprised district officials and some councillors, who discussed their vision for the roles of the council and the community and then summarised their views in a presentation to a plenary session. Their vision was described by the process facilitators as 'revolutionary', in that it represented a shift from command and control to full devolution. The council saw itself as facilitating and supporting community initiatives, providing arbitration when necessary and coordinating activities amongst villagers, rather than taking charge (Table 3-1).

Table 3-1. Vision for community and rural district council roles in natural resources management

\begin{tabular}{|c|c|c|}
\hline Governance issue & Community roles & Rural district council roles \\
\hline $\begin{array}{l}\text { Formulation of rules and } \\
\text { constitutions }\end{array}$ & $\begin{array}{l}\text { Propose laws, rules and } \\
\text { constitutions }\end{array}$ & $\begin{array}{l}\text { Rationalise, adopt proposed } \\
\text { rules and constitutions }\end{array}$ \\
\hline Enforcement & $\begin{array}{l}\text { Employ monitors and } \\
\text { apply sanctions }\end{array}$ & $\begin{array}{l}\text { Arbitrate, review system, } \\
\text { train monitors }\end{array}$ \\
\hline Fines, levies and royalties & $\begin{array}{l}\text { Set levels, impose, } \\
\text { collect }\end{array}$ & Approve, monitor \\
\hline Distribution of revenue & $\begin{array}{l}\text { Propose distribution } \\
\text { systems for revenues, } \\
\text { prepare budgets }\end{array}$ & $\begin{array}{l}\text { Negotiate, approve, } \\
\text { monitor }\end{array}$ \\
\hline $\begin{array}{l}\text { Research and development } \\
\text { projects }\end{array}$ & $\begin{array}{l}\text { Prioritise projects, } \\
\text { identify participants }\end{array}$ & $\begin{array}{l}\text { Coordinate amongst } \\
\text { villages, support project } \\
\text { applications }\end{array}$ \\
\hline $\begin{array}{l}\text { Maintenance (e.g., boreholes, } \\
\text { dip tanks) }\end{array}$ & Implement, fund & Monitor, evaluate \\
\hline Land use planning & Produce plans & $\begin{array}{l}\text { Facilitate, coordinate } \\
\text { amongst villages, approve }\end{array}$ \\
\hline Monitoring and evaluation & $\begin{array}{l}\text { Undertake monitoring } \\
\text { and evaluation }\end{array}$ & $\begin{array}{l}\text { Facilitate, coordinate } \\
\text { amongst villages, approve }\end{array}$ \\
\hline
\end{tabular}

Source: Campbell et al. (2000).

\section{Reflections on visioning processes}

New resource governance arrangements, of course, are more easily envisioned than implemented. This section looks at some of the emerging lessons, constraints and challenges, especially those that relate to the adaptive management of natural resources. 
Long-term commitment by external facilitators. The vision presented in Table 3-1 was the outcome of a long process of negotiation and reflection. Although the vision itself emerged from an afternoon working group session, it actually began 18 months previously, when researchers and stakeholders in the community and at the district level started participating in the research project. In addition, the council's chief executive officer had been a member of the project steering committee. Interactions over the project life surely contributed to the 'success' of the visioning exercises. Also, two of the research team members had lived in the villages for the previous year, building a rapport with the meeting's participants. Adaptive management benefits from high levels of commitment.

Implementation and follow-up. Although external facilitation guided the development of a shared vision by the local communities and the rural district council, facilitation of its implementation was left to the council and other local players. Later visits to the study sites showed that there was no follow-through by either (Kozanayi 2008, pers. comm.). There is need for some follow-up if the visions are to be realised. In addition, the departures of the council's chief executive officer and the district administrator, who had been actively involved in the visioning processes, affected implementation. Both are civil service positions whose occupants can be transferred at any time. Adaptive management, however, requires continuity.

Community empowerment as an incremental process. Participatory methods, participatory rural appraisal tools and the Training for Transformation course provided the basis for the visioning workshops. To some extent, use of these participatory methods helped build the confidence of the local community members who later participated in the visioning workshops held at the district level. Thus a multi-stage process of facilitation was the key to helping the communities find their own voices before they could engage with district-level officials.

Language is power. District-level meetings where community representatives are expected to participate require careful planning. For instance, 
although the official language used at district meetings is English, facilitators encouraged use of the local language to ensure that community representatives could understand the proceedings and express themselves. Another strategy was to ask the villagers to make their presentations first.

\section{Case 2: Action research on forestry}

The second case revealed local people's perceptions regarding planting and managing native trees. Although planting of exotic trees is common in Zimbabwe's rural areas, planting of indigenous trees has not been widely adopted. More often than not, people have tended to protect and manage indigenous trees growing around their homesteads and on family land rather than plant their own indigenous trees (Clarke 1994). This has also been historically influenced by limited access to resources for investment in the planting and management of indigenous trees, which generally take longer to grow. Forestry extension has also emphasised exotic trees. The action research process therefore resulted in experiential learning by both the participants and the researchers on indigenous trees.

The case involved three tree species: Afzelia quanzensis (mukamba), important for timber and carving; Sclerocarya birrea (mupfura), valued for its wood, bark and fruits; and Brachystegia glaucescens (musasa), mainly used for firewood, fibre and fodder. The process was guided by the four phases of action research cycles: planning, acting, observing and reflecting (King 2000). Planning consists of analysing a complex situation and developing a strategic action plan. 'Acting' involves implementing the plan. 'Observing' is the monitoring of the action taken. 'Reflecting' involves jointly evaluating the results over the whole action research process; important because it allows for continual refinements of all phases that include planning, acting and monitoring. 


\section{Planning for action}

The three tree species were selected based on previous interviews on the importance of trees for the local population, the abundance of the trees in the area and the harvesting pressure. Research assistants who were also members of the community collected seeds for distribution. These seeds were then distributed to interested individuals at a community Christmas party in mid-December 2000, held at a place accessible to most village residents. An open invitation had been sent out by the research team through the local leadership. The research team explained the objectives of the tree planting and management experiment, saying that the project sought to generate knowledge about planting of indigenous trees; there were no additional material benefits to be provided. Community members could choose the tree species they wanted, if any. In the end, the demand for seed outstripped supply, with some people going into the bush to find more seeds for themselves.

Participants were asked to use their own knowledge in planting seeds and managing the seedlings. The researchers anticipated that this process would generate information on existing local knowledge of indigenous tree planting in the area, as well as give the participants an opportunity to 'learn by doing'. At first, 45 people joined the tree planting and management initiative. After group monitoring processes were conducted in February 2001, more people began collecting and planting their own seeds and seedlings from the bush, and by September 2001, 14 new participants had joined the action research group; an increase of 30 percent. More women than men (69 percent) participated, perhaps because men in the area tend to be sceptical about activities with no immediate benefit or minimal economic gains. The same pattern was observed in community garden projects.

\section{Implementation and monitoring}

Programme participants planted their seeds between December 2000 and February 2001. Participatory monitoring phases were planned for February and September 2001. During the monitoring, individual interviews and 
group discussions were conducted. Visits were made to each participant's areas, where the plants were tagged. Data included each participant's demographics, number of seeds received or collected, number planted, number germinated, survival rates, rationale for selection of planting site, management practices, motivation for planting, problems experienced and lessons learned.

Small prizes: items such as hoes, shovels, watering cans and seedlings were given out at each meeting, as incentives. At the February and September 2001 monitoring meetings, participants shared their experiences from the exercise and described the problems they had faced and how they had dealt with them. In the February 2001 meeting, 27 participants (19 women and 8 men) attended. The meeting was facilitated by research team members, and issues raised were noted on a flip chart that everyone could see. The September 2001 meeting was attended by 34 members ( 23 women and 11 men), and participants once again shared their experiences (Box 3-1).

Besides participating in group monitoring activities, some innovative individuals kept their own records on tree planting details, such as the dates seeds were received, date planted, germination dates, dates seedlings were transplanted, where planted and criteria for site selection. For instance, one participant recorded that she transplanted her seedlings near a water source during a dry spell. A farmer indicated that he staggered the transplanting of the seedlings so that he could observe the survival rates of the transplants before transplanting more seedlings.

Although people made efforts to actively participate in the experiment, most participants needed to pursue a variety of livelihood strategies and found that tending wild trees competed with other activities for time. The long periods people had to spend in search of food during the drought made it difficult for them to find enough time to care for their trees. For example, one old woman, Maria, could not be found at her homestead until a fourth visit because she had gone to neighbouring villages in search of food for her orphaned grandchildren. When the research team finally found her, she could not locate the places where she had planted her trees 


\section{Box 3-1. Information sharing by tree planting action research group, Romwe}

Perceived benefits of planting trees. Afzelia quanzensis: wood carvings to sell, shade, logs to sell to wood carvers, medicinal values (e.g., bark mixed with other herbs and sprinkled around the homestead will keep away snakes), private ownership of a tree whose harvesting is strictly controlled by local leaders. Sclerocaryia birrea: fruits that are eaten raw or processed into mukumbi (fruit juice), wooden mortars, medicine (bark), windbreak, shade. Brachystegia glaucescens: fibre, poles, windbreak.

Problems. Termites, drought, long distance to water sources, high mortality of seedlings, destruction of seedlings by animals, lack of suitable land for planting different tree species.

Experimental solutions. Use of ashes, used oil, ground pepper, soapy water and fish 'tea' to control termites; frequent watering during dry spells; use of inverted bottles filled with water to regulate the amount of water applied; transplanting seedlings from the bush to address low germination and survival rates for planted seeds.

Lessons learned. S. birrea germinates faster but grows at a slower rate than $A$. quanzensis and B. glaucescens; germination percentage of $B$. glaucescens is very low; $A$. quanzensis seedlings shed leaves when mature trees shed their leaves; $A$. quanzensis seedlings appear not to grow fast if planted in holes one metre deep (as often recommended by extension agents for most exotic tree species); indigenous trees should be planted in microenvironments that resemble their natural environments; indigenous trees can be planted and are not solely a gift from God.

and found only two seedlings of the 10 seeds she had planted. She said it was difficult for her to find time to water them because she had to feed her grandchildren and had no support from the extended family, since life was tough for everyone. She asked the researchers whether they knew of any organisations that could provide food aid for people who look after orphans, since such assistance would give her time to engage in other productive activities.

Participants in the action research group planned to mobilise more people so that the indigenous tree planting and management project could expand. Some pledged to plant more indigenous trees in addition to the species they had already planted. On the day of the community meeting when results of the action research group were presented, a powerful 
village head planted a tree at the meeting site as a symbol for support for the tree-planting project.

In other cases, even though enthusiastic, participants could not continue to tend their trees because a member of their immediate family or they themselves fell ill. The cases of Mackenzie and Moses, presented below illustrate the effect of long-term illness on community projects.

Mackenzie's story. Mackenzie is a 29-year-old man, married with two children. In May 2001, after planting his seeds and transplanting the seedlings, he fell ill. Previously, he had watered his trees regularly and protected them against goats. During the first days of his illness he continued to reside at his homestead, and his wife took over the tending of his seedlings. In August 2001, he became seriously ill and could not even walk or bathe himself. Because of the burden of caring for him, he and his wife went to live with Mackenzie's father, about 3 kilometres from his homestead. Thus the seedlings could not be watered or cared for. At the time of the visit by two research team members, his seedlings were beginning to die from lack of water. Mackenzie himself died before the end of 2001.

Moses' story. Moses, 32 years old and unmarried, joined the tree planting experiment and planted more seeds than any other member of the group. He tended his trees very well and became one of the winners of the small prizes in the September 2001 monitoring sessions assessment. In March 2002, however, Moses fell ill and could no longer take care of his trees. When Moses became seriously ill, his mother took him back to her homestead; he then inherited the wife of his late brother and moved to his late brother's homestead, about 4 kilometres away. His wife and her children could not assist with caring for trees because they were busy growing sugarcane and vegetables, and he could no longer check on his trees because he lived too far away.

The above cases illustrate the impact of chronic illness on community projects. Such illnesses are often associated with the HIV/AIDS pandemic, 
although the HIV status of an ill person is rarely disclosed. This also highlights the fact that livelihoods in semiarid systems are constrained by so many factors, some which may not have been expected.

Drawing from the information presented in Box 3-1, it can be seen that action research leads to both anticipated and unexpected results. One of the challenges faced relates to the identification of the participants in the process. In the action research on trees, participation was on a voluntary basis, and thus the researchers could not ensure balanced participation by different groups, or sexes. Several participants admitted that they were more curious about the experiment than interested in indigenous tree planting, which raises the issue of sustainability of the initiative when external facilitators pull out. In fact, in 2002, when the political situation in the country became tense and restricting, the external facilitators could no longer remain at the study site. Informal visits by one team member revealed that the group's activities had slowed down, perhaps due to the premature exit of the research team. Given the political environment in rural areas of Zimbabwe before the 2002 presidential elections, researchers had no chance to develop an appropriate exit strategy. This suggests that facilitators should develop an exit strategy at the outset so that even if they have to depart abruptly, the local participants can sustain the project.

The learning and information sharing platforms, such as the group monitoring sessions, were found to be very important forums. They enabled lessons learned during the action research process to be shared and discussed.

\section{Lessons learned}

This section returns to the issues raised in the introduction and offers lessons from the two case studies. Aspects that have a bearing on adaptive management include social capital, the importance of facilitation, and macro socioeconomic and political factors. 


\section{Social capital}

The success of participatory processes is apparently built on social capital, which can be a basis for community mobilisation. This was observed in the action research groups, where people shared knowledge and information in both formal and informal arenas. Social capital therefore manifested itself in two ways, in the 'formal' action research groups and in informal arenas. But social capital is not always the solution to the problems of collective action (Portes 1998; Petrzelka and Bell 2000). In the case of Chivi, the ruling elites in local communities have considerable social capital and strong networks and relationships that control many aspects of life, but often to the detriment of other households. For instance, this group dominated the visioning exercise and their influence had to be moderated by the external facilitators. The role plays used to highlight these power dynamics contributed towards toning down the dominant groups.

\section{Importance of facilitation}

The researchers sought to facilitate broader resources management in Romwe and Mutangi by reviewing and attempting to modify the command and control system of governance (Mandondo 2000, 2001). Through visioning meetings with communities and district officials, a new course was set for a new system of management, with considerable devolution of authority to the village level. Facilitation was also crucial for establishing the action research group on trees and creating platforms for information sharing.

Devolution of authority can reinforce capture of benefits by local elites at the expense of less privileged community members. But excluding elites from positions of governance and participation in development projects could undermine the system because they are influential people in their communities (Nemarundwe 2003). Given the problems of village governance, considerable attention will need to be given to facilitating the development of accountable and adaptive governance structures. 
Fluidity of local structures may also hurt development initiatives and reduce the momentum that would have been gained. For instance, the departure of the chief executive officer and the district administrator from Chivi Rural District Council derailed the initiatives to develop new resource governance arrangements. Their successors needed time for orientation, and they may also have had different visions regarding how natural resources should be governed. This cut short the implementation of activities planned to realise the visions developed during the scenario building exercises.

\section{Macro socioeconomic and political factors}

The effect of HIV/AIDS undermined the action research group on indigenous tree planting and management. In the three villages centred on the Romwe catchment, 24 percent of households had lost a member in the previous $4 \frac{1}{2}$ years. This is an average of 13 deaths per 1,000 persons per year, 37 percent above the national average at the time of the last census (1992). Some families have lost as many as seven members (Campbell et al. 2002). It is not possible to attribute the deaths to HIV/AIDS with confidence, since the causes of death are not discussed openly. However, circumstances strongly suggest that most of the deaths were the result of HIV/AIDS. Key informant interviews and participation by the local researchers in all aspects of daily life in the community indicate that HIV/ AIDS-related morbidity and mortality are also hurting local livelihoods (and not only development projects), through the loss of remittances from a breadwinner (with implications for crop inputs, livestock purchases, school fees), the loss of labour (because of illness and death, time needed to care for the terminally ill, attendance at day-long funerals), and the income spent on health care and funeral expenses.

The post-2002 political situation in Zimbabwe forced the untimely withdrawal of the external facilitators, to the detriment of project activities. This suggests the need for planning an exit strategy for any project or programme and making project participants aware that external facilitators will not always be available. 


\section{Conclusion}

Experiences from Chivi show that natural resource management in semiarid regions is far more about local people; the users of the resources themselves, than it is about technical interventions from outside. It depends on community participation, which in turn depends on incentives (Campbell et al. 2001). National programmes that have taken a top-down approach, and have failed to involve the local community, lacking appropriate delivery mechanisms at ground level and neglecting to generate the interest of local people, have failed despite considerable investment and effort (Frost and Mandondo 1999; Campbell et al. 2001). On the other hand, more participatory community-based programmes have been limited in their effectiveness by their small scale, slow rate of replication and often high transaction costs. The two cases from Chivi illustrate this point.

Thought needs to be given to the role of higher levels of governance in creating an enabling environment in which effective natural resource management at the community level can develop (Campbell et al. 2001). There is a need to identify approaches to implementing natural resources management that engender active participation and reconcile the top-down (national) and bottom-up (community-based) approaches, since both are needed to achieve effective management of natural resources. Given the fast-changing socioeconomic and political contexts, community-based natural resources management approaches must be adaptive and able to respond to external factors. 


\section{Endnotes}

${ }^{1}$ The name 'Rhodesia' came into use in 1895 . The designation 'Southern' was adopted in 1901 to refer to the territory on the southern side of the Zambezi River (now Zimbabwe) while the territory of the northern side of the Zambezi River was referred to as Northern Rhodesia (now Zambia).

2 This is a type of well that has horizontal boreholes radiating at different points from the main well shaft, which facilitates the collection of water from fissures in the surrounding rock. These wells are relatively shallow (around $12 \mathrm{~m}$ ), are very reliable water sources, but are more expensive to construct.

3 The team facilitating the visioning/scenario building exercises comprised W. Kozanayi, M. Mutamba, S. Siziba, A. Mandondo, O. Mabhachi and F. Mugabe. 


\section{References}

Barrow, E., Clarke, J., Grundy, I., Kamugisha-Ruhombe, J. and Tessema, Y. 2002 Analysis of stakeholder power and responsibilities in community involvement in forest management in Eastern and Southern Africa. Forest and Social Perspectives in Conservation 9. International Union for the Conservation of Nature, Geneva.

Campbell, B.M. and Sayer, J.A. (eds.) 2003 Integrated natural resource management: Linking productivity, the environment and development. CABI Publishing in association with Center for International Forestry Research, Wallingford, Oxon, U.K.

Campbell, B.M., Jeffrey, S., Kozanayi, W., Luckert, M., Mutamba, M., and Zindi, C. 2002 Household livelihoods in semi arid regions: Options and constraints. Center for International Forestry Research, Bogor.

Campbell, B.M., de Jong, W., Luckert, M., Mandondo, A., Matose, F., Nemarundwe, N. and Sithole, B. 2001 Challenges to proponents of common property resource systems: Despairing voices from the social forests of Zimbabwe. World Development 29(4): 589-600.

Campbell, B., Mandondo, A., Lovell, C., Kozanayi, W., Mabhachi, O., Makumire, T., Mugabe, F., Mutamba, M. and Siziba, S. 2000 Forging new institutional arrangements for common property resource management: A case study from southern Zimbabwe. Institute of Environmental Studies, University of Zimbabwe, Harare.

Clarke, J. (ed.) 1994 Building on indigenous natural resource management: Forestry practices in Zimbabwe's communal lands. Zimbabwe Forestry Commission, Harare.

Critchley, W. and Turner, S. 1996 Successful natural resource management in Southern Africa. Gamsberg Macmillan Publishers (Pty) Ltd.

Dzingirai, V. 1998 Human migration and natural resources management in Zimbabwe's communal lands: The case of Binga. Doctor of Philosophy Thesis. Centre for Applied Social Sciences. University of Zimbabwe. Harare. 
Frost, P. and Mandondo, A. 1999 Improving rural livelihoods in semi arid regions through management of catchments. Institute of Environmental Studies, University of Zimbabwe, Harare.

Gerhardt, K. and Nemarundwe, N. 2006 Participatory Planting and Management of Indigenous Trees: Lessons from Chivi District, Zimbabwe. Agriculture and Human Values 23(2): 231-243.

Jennings, A.C. and Huggins, G.M. 1935 Land apportionment in Southern Rhodesia. Journal of the Royal African Society 34(136) (July): 296-312.

Jiggins, J. and Röling, N. 1999 Adaptive management: Potential and limitations for ecological governance. International Journal of Agricultural Resource Governance and Ecology Introductory Lecture on Challenges for Adaptive Management.

King, C.A. 2000 Systemic processes for facilitating social learning: Challenging the legacy. Agraria 233, Swedish University of Agricultural Sciences, Uppsala.

Mandondo, A. 2000 Forging (Un)democratic resource governance systems from the relic of Zimbabwe's colonial past. Institute of Environmental Studies. Harare.

Mandondo, A. 2001 Allocation of governmental authority and responsibility in tiered governance regimes: The case of Chivi Rural District Council land use planning and conservation by-laws. African Studies Quarterly. http://web.africa.ufl.edu/asq/v5/v5i3a3.htm.

Matondi, P.B. 2001 The struggle for access to land and water resources in Zimbabwe: The case of Shamva District. Agraria 297, Swedish University of Agricultural Sciences, Uppsala.

Murphree, M.W. 1993 Communities as resource management institutions. Gatekeeper Series No. 36. International Institute for Environment and Development, London.

Nemarundwe, N. 2001 Institutional collaboration and shared learning for forest management in Chivi District Zimbabwe'. In E. Wollenberg, Edmunds, D., Buck, L., Fox, J., and Brodt, S. (eds.). Social Learning in community forest management: Linking concepts and practice. Center for International Forestry Research. Bogor. 
Nemarundwe, N. 2003 Negotiating resource access: Institutional arrangements for woodlands and water use in southern Zimbabwe. PhD thesis. Department of Rural Development Studies Swedish University of Agricultural Sciences, Uppsala.

Nemarundwe, N. 2004 'Social charters and organisation for access to woodlands: Institutional implications for devolving responsibilities for resource management to the local level in Chivi District, Zimbabwe.' Society and Natural Resources 17:279-291.

Petrzelka, P. and M.M. Bell. 2000 Rationality and solidarities: The social organisation of common property resources in the Imdrhas Valley of Morocco. Human Organisation 59(3): 343-352.

Portes, A. 1998 Social capital: Its origins and applications in modern sociology. Annual Review of Sociology 24: 1-24.

Ribot, J. C. 1999 Decentralisation, participation, and accountability in Sahelian forestry: Legal instruments of political-administrative control. Africa 69(1): 23-65.

Shackleton, S. and Campbell, B. 2001 Devolution in natural resources management: Institutional arrangements and power shifts. A synthesis of case studies from Southern Africa. WWF-SARPO, USAID SADC NRM and Center for International Forestry Research, Harare.

Siziba, S., Mutamba, M., Kozanayi, W., Mabhachi, O., Mandondo, A., Mugabe, F., Makumire, T., Lovell, C. and Campbell, B. 2000 Attempting to forge new institutional arrangements for common property resource management - scenario building. Institute of Environmental Studies report. University of Zimbabwe, Harare.

Wollenberg, E., Edmunds, D. and Buck, L. 2000 Using scenarios to make decisions about the future: Anticipatory learning for the adaptive comanagement of community forests. Landscape and Urban Planning 47: 65-77. 
A Zimbabwean landscape

(Photo by Brian Belcher)

Chapter4

A weighted decision and tenurial niche approach to analyzing adaptive learning in the social forests of northeastern Zimbabwe

Catherine Chahweta

Alois Mandondo 
The merits of adopting an adaptive perspective to natural resource management among the rural poor are now more readily understood and accepted. Improving people's adaptive abilities is hypothesized to deliver better results than expert-driven approaches (Sayer and Campbell 2003; Douthwaite et al. 2003), largely because adaptive approaches provide an inclusive 'learning paradigm' in which outside experts and local people engage and learn together (Sayer and Campbell no date). The adaptive learning paradigm is ideally based on a cyclic learning model in which an expert helps farmers and local resource users understand their situation, reflect on ways forward, implement appropriate corrective actions and evaluate the outcomes of the actions as a basis for the next cycle of learning (Douthwaite et al. 2003; Hagmann et al. 2003).

But adaptive approaches to natural resource management are often easier proposed than implemented. In practice, adaptive learning experiences seldom assume the order and tidiness of 'textbook' models of adaptive learning, which imply smooth cycles of doing things together and reflecting on how they can be done better. The ensuing outcomes often entail new and ever-changing arrays of interests and actors whose priorities may bear little relation to those for which potential change may initially have been desired. The uncertainty of outcomes in adaptive learning initiatives arises from the complexity of the real world (Ruitenbeek and Cartier 2001), which is often understated or ignored in studies documenting the implementation of such initiatives. This chapter reports and reflects on the 'order and disorder' of a practical adaptive learning encounter in a Zimbabwean social forest ${ }^{1}$. The order and disorder closely accord with the observation made by Prabhu et al. (2007) that adaptive learning involves both weaving through the spaces and going back and forth between the phases as the learners experience bumps in the road together.

The order and disorder arise, in part, because as centres of consciousness within the world, human beings act both singly as individuals and interact in groups at a range of scales. In that sense, choices arrived at within adaptive learning arenas will encompass elements of deciding for others, deciding with others, and deciding for oneself (Reason and Heron 1995). 
Difficulties in decision making at these scales may limit the scope for thorough adaptive learning cycles, at times necessitating shortcuts. The difficulties may be exacerbated by the sheer number, and ever-changing nature, of actors in adaptive learning forums, as well as the ever-changing nature of their interests and priorities. Moreover, people have varying interests and priorities, which means that their acceptance of decisions whether the decisions were made by others, with others or by themselves alone - often changes in complex and unpredictable ways. Coordinating decisions across scales of social organisation therefore poses a real challenge to those aspiring to help local people navigate the action and reflection turns $^{2}$ of adaptive learning cycles. We do not as yet have a full toolkit for creating decision-making frameworks. Reason and Heron (1995 p. 1) nevertheless, offer the following observations on balance in decisionmaking scales in adaptive learning encounters:

When properly done, decisions made for others provide appropriate direction by those with greater vision, skill and experience. Decisions made with others root the individual within a community of peers, offering basic support and the creative corrective feedback of other views and possibilities. And decisions made for oneself express the self-creating and self-transfiguring potential of the person.

The adaptive learning paradigm demands a lot of thoroughness in terms of facilitation. But in practice, the attainment of such rigour is usually constrained by the often shifting nature of choices people make, and their ability, as they seek to decide for others, with others and for themselves. Records of adaptive natural resource management experiences are often less than honest about the inevitability of shortcuts in such settings. And nowhere are sincere confessions more important than in understanding what motivates people to participate in joint experimentation and research. In the literature on adaptive natural resource management, the ideal entry points to cycles of adaptive learning are said to be those that present plausible promises of beneficial change (Sayer and Campbell 2003). Effecting desirable change is often likened to pushing the right buttons (Ruitenbeek and Cartier 2001). Pushing the right buttons and pursuing 
plausible promises are, more often than not, conducted on the basis of best bets that reputedly often rely on good doses of common sense (Sayer and Campbell no date). Such catch phrases are part of a vocabulary of shortcuts through which formal adaptive learning processes are often jump-started and systematized, usually on the basis of decisions made for others. But if convenience is the advantage of top-down decision making, then arbitrariness and lack of transparency may be its disadvantages, with the reverse most likely holding true for decisions made with others.

This chapter provides reflections on empirical processes bearing on scales of decision making in adaptive management initiatives, from the 'learning whilst doing' experiences of woodland management and conservation in the Mawanga Ward of Mutoko District in northeastern Zimbabwe. The Mawanga woodland management project was promoted by a Belgiansponsored development NGO called VeCo. The initiative brought together a variety of actors, including ordinary villagers, local leaders and officials from the country's Forestry Commission and Department of Natural Resources. VeCo's previous and ongoing work in Mutoko District focused on enhancing sustainable livelihoods among the rural poor. Adaptive approaches to woodland management in Mawanga were promoted at a range of scales, including interventions with individuals, households and entire communities; all in partnerships with external organisations. The multi-scale nature of the project gives us insights into the order and disorder of decision-making processes in adaptive learning arenas. Although each decision framework may be appropriate in some particular situation, we suggest that wherever deciding for others or with others is equally applicable, the collaborative approach is better because it internalizes the costs and benefits of resource use and management.

We first describe the context of the study and the entry point into learning whilst doing, then the resource management issues as identified through collaborative learning. Management plans were then devised, after which the community reflected on their outcomes. 


\section{Context}

Mutoko District, centred on $17^{\circ} 20^{\prime}$ south and $32^{\circ} 20^{\prime}$ east, lies in the northeast of Zimbabwe (Figure 4-1). The district covers a total of 4,291 $\mathrm{km}^{2}$ of land. Communal areas, most of which are in the northern and eastern portions of the district, make up a major proportion of the land area. The southeastern and western parts of the district feature small-scale farms and resettlement areas. Mutoko District has a total of 29 wards, including Mawanga, which lies in a communal area close to Mutoko Centre.

Agricultural production throughout much of Mutoko is constrained by a low and erratic rainfall regime averaging $600 \mathrm{~mm}$ per annum. The sandy soils throughout much of the district further limit agricultural potential (Brinn 1986). The nutrient status of sandy soils of granitic origin is invariably low (Kay 1975). Sands are 'hungry soils' that are easy to cultivate but difficult to maintain at a good nutrient status (Grant 1976). Agricultural production in Mutoko is mainly restricted to rainfed cropping in summer. Mutoko is not subject to winter frosts and is therefore conducive to the production of irrigated vegetables where water is available (PTA 1982). Mutoko's rocky summits and valleys are associated with perched water tables and narrow drainage lines, respectively (Brinn 1986). The terrain offers considerable scope for localized water harvesting for market gardening, with tomatoes being by far the most important crop. Much of the vegetation in the district has broad affinities to miombo woodlands, whose dominant genera include Brachystegia and Julbernardia. Because of population pressure associated with dense settlement patterns averaging 34 persons per $\mathrm{km}^{2}$, much of the woodland cover in Mutoko has been opened up for cultivation (Brinn 1986). Remnant woodlands in communal areas occur in relatively inaccessible hills and mountains. Planted mango trees are a major component of intensively cultivated areas. Cattle numbers are generally high, with commensurately high grazing pressure that exacerbates the poor land cover conditions (Brinn 1986). 


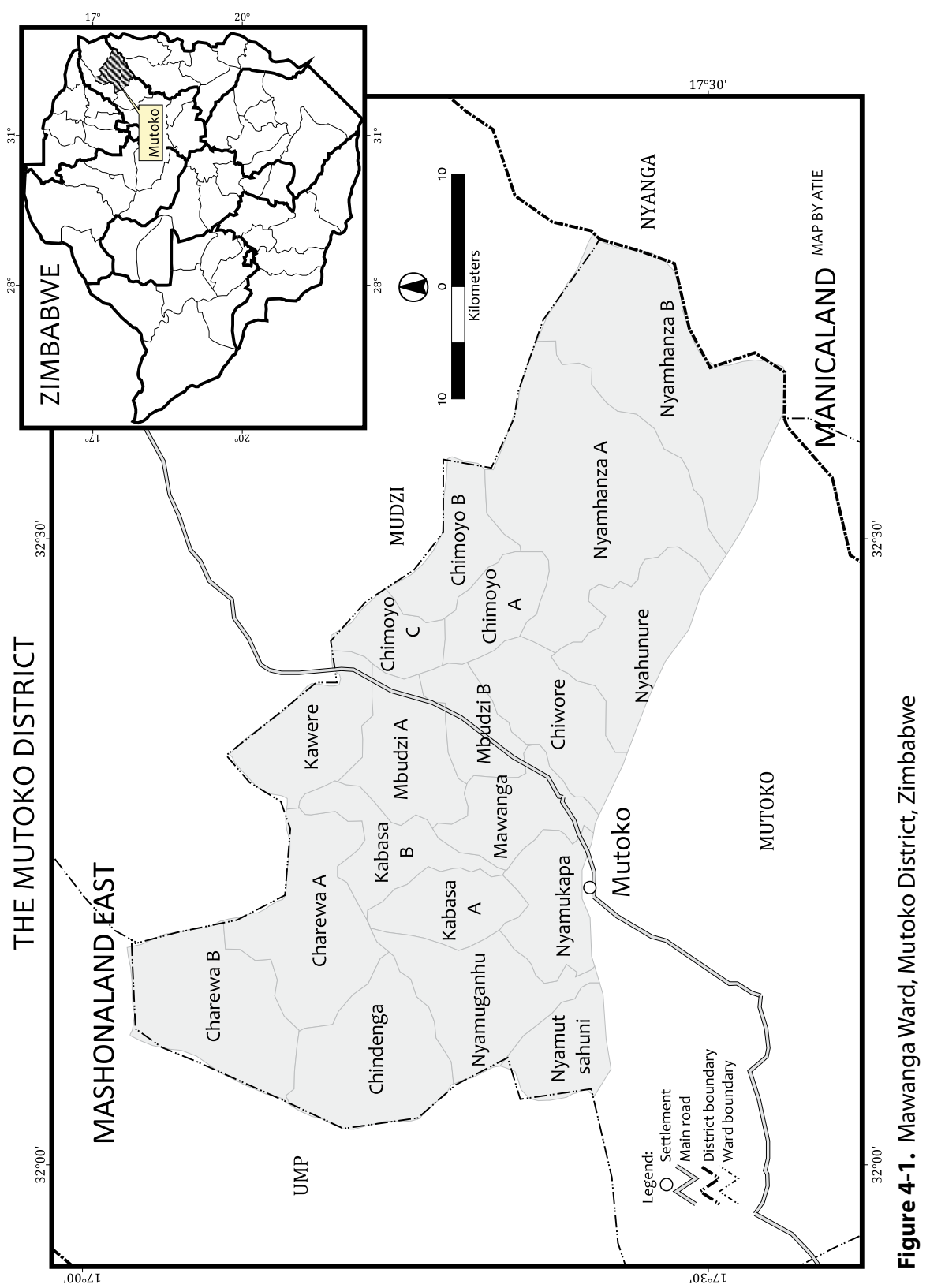


According to the land laws, all communal areas in Zimbabwe are effectively state lands, with custodianship vested in the president. The administration of such land and its resources is delegated to rural district councils. Rural communities enjoy usufruct rights to the land and its resources. In practice, this framework of a central rights structure exists side by side with an informal customary rights regime that is presided over by local traditional leaders, including chiefs, headmen and village heads. At the communal interface, the two rights structures work out into a tenure system that accords peasants de facto traditional freehold rights to arable and residential plots, beyond which there are woodland and other commons. Resources are usually accessed from the commons under various forms of collective and non-collective relations.

Such a tenure system has implications for the loci of decision making in adaptive learning processes. Decisions pertaining to the private arable and residential plots are generally individual, although decisions by others or with others also filter down and affect these levels. Moving on to resources held and used in common, is when, presumably individual decision making should give way to collective decision making. The commons therefore require an institutional mechanism through which many individual preferences are reconciled into shared sets of preferences and collective choice that are rooted within a community of peers. Individual decision making in this arena often results in what is commonly referred to as the tragedy of the commons (Hardin 1968).

Top-down decision making can limit the scope for decisions made at a lower level, whether collective or individual. Invoking freedom, individuals and local communities may be inclined to condemn all decisions handed down from above. But nobody can claim to know better than everyone else in adaptive learning processes, because such processes are by their very nature often group-based and practiced in administrative settings that involve multiple scales. Externally made decisions often have much to contribute to the formulation of decisions made at the local level, and vice versa. 


\section{Entry points to adaptive learning}

The woodland management project reported in this chapter was one among a series of interventions introduced under VeCo's Mutoko Agricultural Development Programme. The programme was launched in 1989 under a district-level tripartite agreement that included the national agricultural extension agency (Agritex), the Mutoko Rural District Council, and Coopibo (the original name of $\mathrm{VeCo}$ ). VeCo's work has, over the years, involved strengthening the capacity of local communities by facilitating the development and dissemination of appropriate technologies in sustainable agriculture. The project in Mawanga was one of several interventions promoted by $\mathrm{VeCo}$, and it was conducted over the five-year period from 1997 to 2002.

VeCo collaborated with local communities in identifying deforestation as the major problem pertaining to the management of woodlands in the Mawanga Ward, providing the entry point for adaptive learning for this project. The successful emergence of such collaboration lends weight to the observation that no side enjoys monopoly of insight in adaptive learning encounters. Thus, the importance of VeCo's intervention cannot be condemned solely because it came from outside but must be evaluated on its salience and relevance to the communities. Salience and relevance are best demonstrated through enduring interest in the initiative and its results, both of which are central issues in this chapter. Furthermore, interest is more enduring with results being better when decisions are made with others than when they are made for others and imposed on them. The concept of tenurial niches is borrowed from Bruce et al. (1993), who use the term to acknowledge the biophysical and institutional heterogeneity of woodlands in communal and other settings.

The deforestation across tenurial niches in the district presumably reflects woodland use and management. The sparse vegetation in homestead and arable plots has probably resulted from clearing for cultivation and planting of exotics, whilst the commons is a woodland remnant, from which various non-timber forest products are extracted. Local resource management arrangements based on deciding with others usually operate 
through a combination of formal rules and informal norms and taboos, most of which are steeped in culture (Mandondo 1997). In part because of the erosive effect of overarching national regimes, in which a few people made decisions for many others, most such local controls are ineffectual (Campbell et al 2001). Decisions made for oneself in communal area settings often pertain to traditional agroforestry practices, usually those resulting in the retention of some trees in the 'privately' held homesteads and fields and planting exotics, such as mangoes and eucalypts in such areas (Wilson 1989).

VeCo's facilitation work in the woodlands of Mutoko sought to address the underlying problems in misaligned decision making, of which deforestation was but a symptom. To begin, VeCo collaborated with local communities in identifying deforestation as the major problem for management of woodlands in Mawanga.

\section{Drivers of woodland depletion}

Searching for solutions to deforestation involved prior identification of problems through intensive interactions among those involved. People were brought together in adaptive learning forums through a methodology termed participatory learning and action. Group introspection and reflection in these forums involved 'problem tree' analyses, in which people traced the immediate problem of woodland depletion to its underlying causes (Figure 4-2).

The participatory learning and action sessions also provided a platform for the people to reflect on some demand-side features of deforestation, including their estimates of the amount of wood required by an average village for various activities. The consensus was that action needed to be taken not only on the supply side within the woodland, but on the demand side as well. Table 4-1 presents the average estimates of wood use for various activities within one village. Although the list of activities is not comprehensive, it provides some insight into local perceptions of the rate of woodland depletion. 


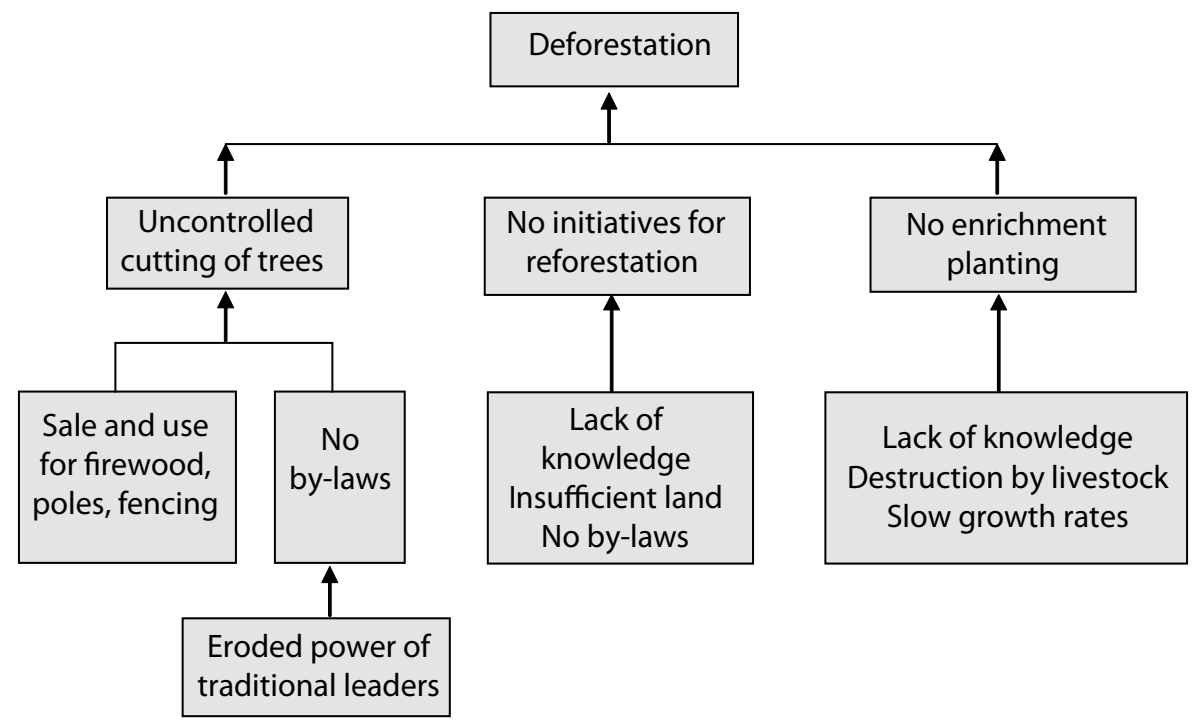

Figure 4-2. Problem tree of underlying causes of deforestation in Mutoko

Table 4-1. Estimates of wood use in a 75-family village, Mawanga Ward

\begin{tabular}{ll}
\hline Use & $\begin{array}{l}\text { Average area of woodland or quantity of } \\
\text { wood required per year }\end{array}$ \\
\hline Firewood for household consumption & 1 acre of woodland \\
\hline Firewood for brewing beer & $1 / 2-3 / 4$ acre of woodland \\
\hline Brickmaking & $40-100$ ox carts of timber \\
\hline Poles & $6-25$ ox carts of timber \\
\hline
\end{tabular}

The gravity of the problem revealed by these estimates led the villagers to reflect more deeply on the root causes, particularly the existing resource management arrangements in which decisions made by central officials displaced those made at the local level. They realised the ineffectiveness of organisations charged with enforcing hierarchical regimes of woodland use and management, particularly the national police force, the Forestry Commission, the state Natural Resources Board, and the rural district council. The discussion also touched on the role of traditional leaders as the local centres of collective decision making about woodland use and management. Overall, the dialogue pointed towards a need for a change in the roles and relations among the actors. Observations emerging from the meetings included the following: 
Most farmers were unaware of government laws on the use and management of local woodlands. In line with earlier reasoning these are mostly top-down laws.

» Laws made by officials were ineffective in controlling deforestation. In line with our typology, these are laws made by higher-level officials for people.

» Farmers were somewhat aware of top-down, district-level by-laws (Mandondo 2001). These too are 'laws made by officials for people'.

» Farmers were more aware of local, collectively made laws; that is, those involving local people in collaboration with their chiefs and enforced through the headmen and village heads with the support of the community.

» Decisions made by the people in collaboration with their own leaders were recognised as having greater scope for success.

» Although traditional leaders have lost their power as the major actors in making collective decisions at the local level, they were still respected by the farmers.

Thus, even at the most basic level of simply assessing perceptions, the preliminary dialogue appeared to lend weight to the hypothesis that regimes in which people make decisions with others have greater potential to be relevant, effective, and legitimate compared with regimes in which decisions are made by a few for others. The preliminary reflections suggested that far from being a solution, existing regimes were, in fact, the underlying cause of the problem. The joint reflections gave expression to shared concerns that led to the emergence of a common vision on how the above, and other forms of problems could best be tackled. In keeping with the Bruce et al. (1993) tenurial niche formulation, the common vision did not involve a generic antidote to the declining woodlands across the entire length and breadth of Mawanga. Rather, the programme of action suited each area's particular challenges, and options based on decisions made for oneself and with others tended to find greater favour than those based on decisions made for the majority by a few (Table 4-2). The programme of action included a broad range of woodland management options; some to reduce wood demand, others to enhance wood supply. 
Table 4-2. Proposed programme for addressing woodland depletion, Mawanga Ward

\begin{tabular}{lllll}
\hline Problem & Solutions & $\begin{array}{l}\text { Most } \\
\text { appropriate } \\
\text { tenurial } \\
\text { niche }\end{array}$ & $\begin{array}{l}\text { Demand } \\
\text { or supply } \\
\text { strategy }\end{array}$ & $\begin{array}{l}\text { Most } \\
\text { appropriate } \\
\text { management } \\
\text { system }\end{array}$ \\
\hline $\begin{array}{l}\text { Uncontrolled } \\
\text { cutting of } \\
\text { trees }\end{array}$ & $\begin{array}{l}\text { Formulating and } \\
\text { introducing local } \\
\text { by-laws }\end{array}$ & $\begin{array}{l}\text { Woodland } \\
\text { commons }\end{array}$ & $\begin{array}{l}\text { Curtailing } \\
\text { demand }\end{array}$ & $\begin{array}{l}\text { Decisions made } \\
\text { with others }\end{array}$ \\
\hline $\begin{array}{l}\text { Uncontrolled } \\
\text { cutting of } \\
\text { trees }\end{array}$ & $\begin{array}{l}\text { Introducing } \\
\text { chingwa stoves }\end{array}$ & $\begin{array}{l}\text { Homestead } \\
\text { kitchens }\end{array}$ & $\begin{array}{l}\text { Curtailing } \\
\text { demand }\end{array}$ & $\begin{array}{l}\text { Decisions made } \\
\text { for oneself in } \\
\text { implementation, } \\
\text { with possibilities } \\
\text { of deciding with } \\
\text { others in sharing } \\
\text { lessons }\end{array}$ \\
\hline $\begin{array}{l}\text { Inadequate } \\
\text { reforestation }\end{array}$ & $\begin{array}{l}\text { Implementing } \\
\text { protection } \\
\text { rotation scheme }\end{array}$ & $\begin{array}{l}\text { Woodland } \\
\text { commons }\end{array}$ & $\begin{array}{l}\text { Supply } \\
\text { enhancement }\end{array}$ & $\begin{array}{l}\text { Deciding with } \\
\text { others }\end{array}$ \\
\hline $\begin{array}{l}\text { Lack of } \\
\text { sufficient } \\
\text { numbers of } \\
\text { useful trees }\end{array}$ & $\begin{array}{l}\text { Planting more } \\
\text { valuable trees in } \\
\text { cultivated areas } \\
\text { (enrichment } \\
\text { planting) }\end{array}$ & $\begin{array}{llll}\text { Homesteads, } \\
\text { fields, gardens }\end{array}$ & $\begin{array}{l}\text { Supply } \\
\text { enhancement }\end{array}$ & $\begin{array}{l}\text { Deciding for } \\
\text { oneself }\end{array}$ \\
\hline
\end{tabular}

Adaptive learning processes have been called 'science in the service of effective action' (Reason and Torbet 2001 p. 5). Such science is even better poised to serve action if it is actor-oriented; that is, if it places people at the centre of their own universe (Reason and Bradbury 2003). But adaptive learning scenarios in real-life universes often involve disparate groups of people with various interests. The broad-based nature of VeCo's work in Mutoko therefore accords with the reality of communal systems in which peasants pursue a diversity of livelihoods (Campbell et al. 2002), of which woodland-based activities are often only one component. The three participatory learning and action meetings in the woodlands of Mawanga attracted 43 farmers from the many participating villages (among them Tsuro, Saramunda, Ndemera, Chiundo, Tsiko and Gonye), each with an average of about 75 families. Traditional leaders were strongly represented at the meetings, and each forum was attended by no fewer than 16 village heads. The meetings presumably attracted few attendees, in part because people have interests besides the woodlands. But the generally high turnout 
of traditional leaders may be taken to represent collective interest. Thus, adaptive learning in the woodlands of Mawanga began not with universal interest by the entire population, but with high interest on the part of its traditional leaders.

\section{Action to improve use and management of woodlands}

The programme of action to conserve the Mawanga woodlands was a broad strategy of reducing wood demand whilst enhancing supply (Table 4-2). The demand-side strategy sought to curb woodland depletion by collaboratively crafting more effective by-laws. The introduction of energy conserving chingwa stoves would complement the by-laws by reducing demand for wood. The supply-side strategy involved implementing collectively decided regimes of rotational use of the remaining woodland and enrichment planting in the more deforested homestead and arable plots.

\section{Collectively decided local by-laws for conservation}

Participants in Mawanga had agreed on the need to replace official laws with people-driven and collectively decided and agreed regimes of woodland management. Given their central role in such regimes, customary leaders, particularly chiefs and headmen, were assigned unfettered discretionary oversight in determining fines, which they pegged at ZWD 100 for the unauthorized felling of a whole tree. The assignment of this authority to traditional leaders was presumably based on a common-sense approach to reducing the high transaction costs associated with bureaucracies, but arbitrariness and opacity are frequently associated with the exercise of unfettered powers. Whether delegating such power to the chiefs strengthened or weakened the collaborative nature of the effort is discussed below. Here, it is worth noting that it probably accords with traditional leaders' perceived status as legitimate holders of collective interest in communal systems, and thus the new schedule of fines may have accorded with people's perceptions of its deterrence potential, even though only a small proportion of the ward's population participated. 


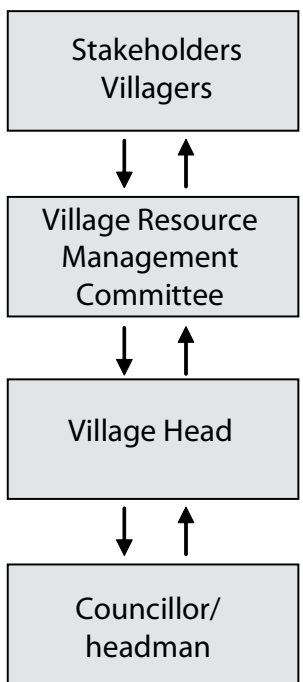

Figure 4-3. Structures to enforce local by-laws in Mawanga woodlands

The same caveat applies to the second step in the crafting of the new woodland management arrangements, determining the by-laws to limit indiscriminate felling of trees. Like the fines, the by-laws were devised by the traditional leaders, and they included the following:

» Only dried trees and branches could be cut from trees in the woodland commons.

» Felling of whole trees required written permission from the village head.

» Cutting of trees for sale was prohibited.

Again, rulemaking by traditional leaders may not necessarily equate with lack of proximity to citizens, since such leaders are generally perceived as legitimate.

The final step, towards the revival of the local by-laws, involved setting up structures for their implementation and enforcement. Unlike the preceding two stages the formation of such structures was opened up to the broader community, and therefore to the greater rigour associated with such inclusive participation. Democratically elected resource management 
committees, of at least three men and three women each per village and presided over by the village head, were to enforce the by-laws. This grassroots structure required support from higher levels to effectively fulfil its mandate (Figure 4-3). For instance, the need to convene complementary courts at the headmen level was recognised as being crucial in dealing with habitual offenders. Thus, adaptive management at the local level fits within the structure of a higher, external system. In other words locally crafted systems were neither necessarily antithetical to principles of hierarchy nor to externally driven laws.

\section{Collectively decided regimes of rotational use}

Tenurial niche formulation combines a biophysical dimension of spatial variations in resource status with an institutional dimension of what is feasible in terms of management within each niche (Bruce et al. 1993). Whereas the by-laws initiative sought to prevent further decline in the deforested areas, the protection rotation scheme sought to maintain and enhance the supply of woodland products from areas that still retained forest cover. The protection rotation scheme, introduced in Chiundo and Tsiko villages, included demarcating the woodlands into three sections with contrasting regimes of use. In one section, the communities could collect only branches; the two other sections were rested on a rotational basis. The protected woodland stocks were further augmented by reforestation. The candidate species for planting were fast growing and would yield multiple benefits. Other silvicultural operations were also undertaken to boost the growth of trees within the protected commons, including planting seeds, transplanting seedlings, watering and pruning.

As part of the facilitation package, VeCo arranged field trips to Mount Darwin in northern Zimbabwe and Domboshawa, close to Harare. Only a few farmers could undertake the trips, but it was expected that they would share what they had learned. The look and learn idea is premised on the assumption that the initial learner is willing to learn and pass on the knowledge, and that the subsequent learner is also willing and able to acquire new knowledge. Such relays often turn out to be jerky and disorderly in adaptive learning cycles, and that may explain the somewhat 
low and fluctuating levels of planting. Nevertheless, look and learn visits have value as tools $s^{3}$ for jumpstarting joint learning in adaptive resource management arenas.

The formation of forest management committees provided the institutional mechanism through which rotations within the woodland could be achieved. The committee orchestrated the silvicultural activities and prudent use in the open block whilst enforcing nonuse within the closed blocks. The scheme is likely to impact not only on the people who happen to be participants in the scheme, but also on people who happen to be users of the woodlands because they live in surrounding areas. Further research is required to ascertain the extent to which decisions made by those currently participating in the schemes tally with the interests of non-participants.

\section{Afforestation}

The woodland is a commons whose resources need collective management, but the homestead and arable plots have more scope for individual choice and discretion. A new set of factors, including shortages of labour, skills and resources, is likely to constrain what can be done in the latter tenurial niches. VeCo therefore sought to provide an enabling environment for tree planting by providing technical and other forms of support. Look and learn visits were the initial idea to spark people's interest in planting trees on their land. One such visit, to an agroforestry demonstration centre in Dombashawa, attracted 16 farmers: 7 men, 3 village heads and 6 women. As earlier argued, the effectiveness of look and learn visits depends on the extent to which the smaller group of initial participants 'spreads the word' to the rest of the community. VeCo sought to make the approach effective by facilitating forums for sequel learning. Initial discussions in three villages targeted for tree planting sought to place people's problems at the centre of their universe, as a basis for reflecting on ways forward. The following were among some of the commonly mentioned constraints to tree planting:

» People lack knowledge about suitable trees.

$»$ Trees compete for light with crops. 
$»$ Trees interfere with land preparation.

» Planted trees are prone to damage by livestock.

$»$ Trees compete for nutrients with crops.

» Trees like eucalypts are heavy water users that dry out the soil.

In discussion forums led by those who had participated in the tours, people discussed potential solutions. For instance, planting broadercrowned and deeper-rooted trees on contours would reduce competition between trees and crops; Acacia leptocarpa, considered good for fuelwood, and Acacia angustina, good for fodder, were mentioned. Shallow-rooted, fertility improving trees, such as Sesbania sesban and Cajanus cajan, could be planted in fields. In general, men preferred planting soil-improving trees on contours, and women were interested in planting different species in both the fields and the contours. Thus, interests in adaptive learning were far from being homogeneous and may show significant differentiation even within a household.

\section{Energy conserving stoves to reduce deforestation}

The adaptive learning cycle often conjures the image of entire populations engaging in neat macrocycles of collective learning and action, but that is usually not the case. In the real world, with its myriad social differences, nested sets of adaptive learning cycles include only some of the potential participants. For instance, the testing and promotion of energy conserving stoves in Mawanga provided a female dominated experience of adaptive learning, and not the participation of all people in the villages. The intervention sought to improve on the faulty design of the stoves promoted by the national Department of Energy; these unwieldy and expensive stoves had poorly designed grates and were made of low-quality material. New stoves designed by local welders provided the entry point to testing and reflection.

\section{Reflections on management action}

Impact assessment is a crucial feature of adaptive natural resource management because it is a tool for adaptation, learning and performance enhancement. It also provides data for further negotiation amongst 
stakeholders and for fine-tuning resource allocation decisions (Sayer and Campbell 2003).

Participatory impact monitoring was the tool that the communities, in conjunction with project facilitators, used to examine the by-laws initiative and designed to enhance analytical capacity and problem solving. Joint monitoring recognised that neither the local people nor the facilitating organisations had any monopoly on accurate interpretation of developments and their implications. The by-laws were monitored at village, project (VeCo ADP) and programme level (VeCo head office), corresponding to the administrative levels in Mawanga. But much of the monitoring was done at the village level to ensure that the project retained the flexibility of a social learning experiment.

Templates for local monitoring were created in brainstorming sessions at the community level, where farmers expressed their fears and expectations as a first step to developing indicators for monitoring trends in woodland use and management. But in line with the 'disorder' formulation made earlier, most of these fears and expectations were "fuzzy" and could not be easily linked to indicators. In the joint monitoring forums, however, fears and expectations could be easily indexed to measurable indicators (Table 4-3). The fuzziness of local systems often arises as a hedge against the high transaction costs associated with explicit and formalized ways of doing things although it can be mistaken for evidence of improvidence and lack of management. In addition to being flexible, such systems can, in their small ways, reputedly achieve and internalize 'small efficiencies'. Thus, drastic switches to intensive management systems should not be allowed to 'sow failure where such small efficiencies are being reaped' (Ruitenbeek and Cartier 2001). The more formal and explicit monitoring tools for the joint monitoring forums thus probably reflect the extent to which external support enables switches to transaction-intensive ways of doing things. In the case of the Mawanga initiative, formal arrangements for monitoring included the following tasks for the committee that was put in place:

» conducting monthly transect walks to observe and record evidence of tree felling; 
Table 4-3. Community fears and expectations together with the related joint template of indicators of woodland use and management in Mutoko

\begin{tabular}{|c|c|c|}
\hline Fears, expectations & Indicators & Scoring* \\
\hline $\begin{array}{l}\text { Awareness of by-laws is } \\
\text { restricted to traditional } \\
\text { leaders, not effectively } \\
\text { shared with villagers. }\end{array}$ & $\begin{array}{l}\text { More people can explain } \\
\text { aims and activities of } \\
\text { initiative, including } \\
\text { by-laws, fines and } \\
\text { dispensing of fine } \\
\text { revenues. }\end{array}$ & $\begin{array}{l}10 \text { points = all can explain } \\
\text { by laws, fines, use of money; } \\
4 \text { points = one quarter can } \\
\text { explain. }\end{array}$ \\
\hline $\begin{array}{l}\text { Awareness of by-laws will } \\
\text { not necessarily lead to } \\
\text { action. }\end{array}$ & $\begin{array}{l}\text { More trees are harvested } \\
\text { in accordance with } \\
\text { standing by-laws, } \\
\text { fewer trees are felled in } \\
\text { successive years. }\end{array}$ & $\begin{array}{l}\text { See records of whole trees } \\
\text { felled in bush. }\end{array}$ \\
\hline $\begin{array}{l}\text { Social pressure will } \\
\text { undermine scope for } \\
\text { consistent imposition of } \\
\text { sanctions. }\end{array}$ & $\begin{array}{l}\text { Fewer culprits are } \\
\text { apprehended, pay fines. }\end{array}$ & $\begin{array}{l}\text { Very good = all apprehended } \\
\text { culprits pay up quickly; good } \\
=\text { culprits pay after several } \\
\text { warnings; bad = none pay } \\
\text { within a month. }\end{array}$ \\
\hline $\begin{array}{l}\text { Committee will not } \\
\text { monitor in effective and } \\
\text { transparent manner. }\end{array}$ & $\begin{array}{l}\text { Joint verification of } \\
\text { committee records } \\
\text { occurs through ground- } \\
\text { truthing excursions to } \\
\text { reflect limited disparities. }\end{array}$ & $\begin{array}{l}\text { Bad = more records of } \\
\text { flouting are encountered } \\
\text { than recorded, leading to } \\
\text { discussions in joint reflection } \\
\text { meetings. }\end{array}$ \\
\hline $\begin{array}{l}\text { Monitoring will worsen } \\
\text { social conflict within and } \\
\text { between villages }\end{array}$ & $\begin{array}{l}\text { Fewer conflicts are } \\
\text { reported at joint } \\
\text { reflection meetings and } \\
\text { at random meetings. }\end{array}$ & $\begin{array}{l}\text { Bad = more conflicts arise } \\
\text { but are not discussed; good } \\
=\text { conflicts that arise are } \\
\text { discussed and solved, or } \\
\text { social conflicts cease. }\end{array}$ \\
\hline $\begin{array}{l}\text { Women will be victimized } \\
\text { in monitoring because of } \\
\text { their low social standing. }\end{array}$ & $\begin{array}{l}\text { Fewer women express } \\
\text { these fears and } \\
\text { reservations during } \\
\text { committee and village } \\
\text { meetings. }\end{array}$ & $\begin{array}{l}\text { Good = only one specific } \\
\text { problem is discussed in each } \\
\text { village. }\end{array}$ \\
\hline
\end{tabular}

*Scoring outcome from random interviews with 20 villagers. 


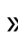

meeting monthly to deliberate and reflect on emerging developments;

$\gg$

meeting quarterly with project staff and the programme officer responsible for methodologies and gender to ensure joint reflection, and to capture cross-scale synergies, support and insights; and

» meeting quarterly with the villagers to present the intervening outcomes of joint actions, and to reflect on best ways forward.

But whereas monitoring templates are usually explicit in design and detail, the initial records from the monitoring programme were far from comprehensive. The first, developed in late 1998, mentioned primarily the apprehension of two culprits in both Ndemera and Saramunda, two of the three villages in which systematic monitoring had been commissioned (the third village was Gonye). Although the culprits confessed and promised to pay the fines, they never were made to pay. The utility of the monitoring templates did not significantly improve in the subsequent year, and the records remained scant. Though fewer large trees were recorded as having been felled in that year in Ndemera, more smaller trees were cut, and most of the violators worked under cover of darkness. More violations were recorded for Saramunda, where much of the wood was used for brickmaking. The disparities between the promise of monitoring templates and the more mundane actual monitoring records reflect the challenges of bridging the gap between the neat designer's world and real world experiences as they occur in practical monitoring in everyday social life.

The complexities and challenges of monitoring in Mawanga arise partly from underlying constraints to collective decision-making regimes, including the uncertainty of sanction, the adeptness of violators at evading apprehension, and people's need to secure their livelihoods. Some of these constraints fall under the rubric of 'the politics of common property', as they were described in an external evaluation of the VeCo project conducted by a SAFIRE ${ }^{4}$ consultant. Most of the constraints are not-unexpected challenges however, when viewed from the perspective of the adaptive learning paradigm, particularly those that are a reflection of the lack of ability to collaborate with others in order to adjust appropriately to challenges that 
may arise. In meetings in Ndemera and Saramunda, people did reflect on the constraints and proposed ways to deal with the challenges: changing committee members more regularly, rewarding monitors who apprehend culprits, rewarding consistent fine collectors and finding more alternatives to wood; the external evaluation report also suggested these ideas.

The monitoring records for 2000 in Ndemera showed a marked trend towards order and detail, with no fewer than six transect walks having been conducted. Monitors saw no evidence of cutting large trees and a declining trend in harvesting smaller trees. Reflection meetings indicated a lack of awareness of the project among children, and participants suggested targeting certain age groups with awareness-raising programmes. Reflection meetings in Ndemera drew people from surrounding villages and helped reduce conflict by brokering appropriate charters of access to resources across villages. The situation in Saramunda, however, remained difficult: the monitoring committee was reportedly weak and ineffectual in apprehending culprits. Thus, although collaborative management of common pool resources is generally problematic, the degree of difficulty varies. Similar experiences emerged from the rotation scheme in Tsiko and Chiundo. Whereas the community in Tsiko appeared more committed to their programme, those in Chiundo were distracted by a donor-funded food-for-work programme centred on construction of a bridge. The drivers of success in managing common resources, as in Ndemera, remain unclear, but perhaps the partnerships that the Ndemera community forged with external stakeholders - CAMPFIRE ${ }^{5}$, the state Forestry Commission, the Poverty Alleviation Action Programme, the Ministry of National Affairs, the District Development Fund and the Ministry of Roads - enhanced the community's capacity to organise for collective action.

Evaluations of the tree-planting efforts suggest that such endeavours fare better for homestead fields than in common areas, as reflected by the monitoring records for 2000 (Table 4-4). This appears counterintuitive when considered from the perspective of economies of scale in land, labour and inputs: logic dictates that there should have been more plantings in the woodland commons. But from the individual farmer's perspective, 
Table 4-4. Disaggregated analysis of trees planted in Mawanga woodlands, 2000

\begin{tabular}{llcl}
\hline Village & Species planted & Quantity planted & Tenurial niche \\
\hline Ndemera & Brachystegia spp. & 20 & Homesteads \\
\hline Ndemera & Eucalypts & 200 & Homesteads \\
\hline Gonye & Eucalypts & 180 & Homesteads \\
\hline Gonye & Eucalypts & 500 & Woodland commons \\
\hline Gonye & Pears & 27 & Homesteads \\
\hline Gonye & Paw paw & 18 & Homesteads \\
\hline Gonye & Masawu & 3 & Homesteads \\
\hline Gonye & Azanzagarckeana & 2 & Homesteads \\
\hline Saramunda & Eucalypts & 700 & Woodland commons
\end{tabular}

considering certainty of reward from own effort, the incentive to plant trees on a homestead plot is greater.

The chingwa stoves were part of the effort to reduce demand for wood. Adoption rates generally remained low over the project's relatively short timeframe, and thus we cannot determine whether the adoption patterns were indicative. A total of 44 stoves were constructed, 81 percent of which were being used. Determining whether the stoves reduced demand for firewood is a somewhat complex endeavour, given the variables. Crude assessments indexed to point of consumption records, nevertheless, generally showed that a chingwa stove could reduce a household's wood demand by as much as 47 percent. This could mean that a household would need only 10 ox carts of wood per year instead of 20 , and only 6 trees instead of 13 . Thus use of the stoves by 35 households would reduce tree harvests from 465 to 231 trees per year. The merits of the stoves notwithstanding, these statistics are useful only to the extent that all other variables are unchanged.

The reflection meetings attracted an average attendance of 20, and never all of the 45 women who owned the new stoves. In the meetings, they discussed the advantages of adopting chingwa stoves: 
» Families can prepare a wide range of foods at the same time.

»Pots are easier to clean because the stoves produce less soot.

» Reduced smoke reduces the incidence of eye and lung infections.

» The stoves' heat retention properties make preparation quicker, and more meals can be prepared from a small quantity of wood.

» Making stoves provides a source of income for women.

Drawbacks of the stoves were mentioned as well:

»Some houses are too small to accommodate the stoves.

»Some walls are too weak to withstand drilling.

» Stoves are not ideal for warming all recesses of entire hut.

》 Reduced emissions of smoke makes it harder to preserve seeds.

» The stoves deprive kitchens of the social status associated with central fires, which is a symbol of marriage and family life.

Some of the drawbacks were considered opportunities for improvement and led to alterations in design, including use of thinner bricks. In general the reflection meetings attracted an average attendance of 20 , and never all of the 45 women concerned, which shows that people with interests in various aspects of adaptive management in the woodlands often balance their time across competing priorities and endeavours.

\section{Discussion}

The findings from this chapter on adaptive learning in Zimbabwe appear to support observations that everyday adaptive learning cycles combine elements of order and disorder. Neatness and chaos reflect both the tension and the harmony associated with efforts to reconcile decisions made for others with those made with others, as well as those made for oneself. Deciding for others is usually faster than working through a complete adaptive learning cycle, as when wide discretionary powers were vested in the chiefs, but it can be opaque and arbitrary. Deciding with others, on the other hand, is more transparent and open to broader scrutiny, but it takes a long time for people to meet and consult before they can 
make decisions, as borne out by the many meetings and exchange visits undertaken to bring people up to speed on adaptive learning and natural resources management.

The institutional and biophysical characteristics of the local landscape define tenurial niches that often determine how decisions can be made. We hypothesized that woodland management interventions are easier to transact and more effective if decisions are made with others rather than for others, particularly for the management of common resources. The evidence appears mixed. Deciding for others appears to work to the extent that others consent to the regime. In participatory learning and action sessions, people perceived central regulatory systems as intrusive because they are top-down, non-participatory and supply-led. But when people were involved in crafting alternative resource management regimes at the local level, they recognised roles for officials at higher echelons of social and administrative systems. For instance, the by-law monitoring regimes in the Ndemera village appear to owe their effectiveness to partnerships with a range of government departments, but similar regimes remained somewhat ineffectual in villages where such bottom-up and top-down synergies had not been established. Additionally, nowhere do we see evidence that local people want nothing to do with hierarchies. People are averse to imposed top-down relations but willing to establish such systems if needed. For instance, people in Mawanga looked outside their villages and involved higher-level headmen to ensure more effective enforcement of their by-laws.

The higher rates of tree planting in homestead plots than in the woodland commons could suggest that in some niches, deciding for oneself provides better incentives for woodland management than deciding with others, especially given the challenges of collective management. But land shortages and resource and input constraints often limit tree planting in individual plots and cannot be resolved simply by embarking on adaptive ways of doing things. Furthermore, the greater promise of deciding for oneself should not imply that the commons be privatized, or that individual use 
of the commons, such as the accelerated tree felling for brickmaking in Saramunda, be lauded as a step towards the 'liberation of the commons'. The commons remains an invaluable resource from which the poorest of the poor often derive their livelihoods, if not their very existence, and they are going to require innovative forms of collective actions (Campbell et al. 2002). 


\section{Endnotes}

${ }^{1}$ The concept of social forest is borrowed from Bruce et al. (1993), and denotes the many intricate linkages that tie people to their forests, as opposed to ways of looking at forests that portray them as mere biophysical entities.

2 The 'action or reflection turns' is a Reason and Torbet (2001 p. 2) formulation that accords with the concept of adaptive management as comprising cycles of doing and reflecting on how things can be done better.

3 And pragmatic ones, for that matter.

4 The Southern Alliance for Indigenous Resources. Although this consultancy complemented the efficacy of local monitoring forums, it can be seen as having constrained the availing of adequate time, resources and effort to initiatives in which the local people could reflect on their own problems within their own universe. In that sense the SAFIRE evaluation would fit into the 'seeing problems' for people instead of the 'seeing problems with people' model.

5 CAMPFIRE stands for Zimbabwe's Communal Areas Management Programme for Indigenous Resources, which extends the benefits of the use of natural resources, particularly wildlife, to peasant communities. The programme achieves this by bestowing custodianship of such resources in the rural district council in which such resources are found. 


\section{References}

Brinn, P.J. 1986 Communal land physical resource inventory, Mutoko District. Report A524. Chemistry and Soil Research Institute, Harare.

Bruce, J., Fortmann, L. and Nhira, C. 1993 Tenures in Transition, Tenures in Conflict: Examples from the Zimbabwe Social Forest. Rural Sociology: 58 (4): 626-642

Campbell, B.M., Mandondo, A., Nemarundwe, N., Sithole, B., de Jong, W., Luckert, M. and Matose, F. 2001 Challenges to proponents of common property resource systems: Despairing voices from the social forests of Zimbabwe. World Development 29: 589-600.

Campbell, B.M., Sayer, J., Kozanayi, W., Luckert, M., Mutamba, M. and Zindi, C. 2002 Household livelihoods in semiarid regions: Options and constraints. Center for International Forestry Research, Bogor.

Chambers, R. 1985 Rural development: Putting the last first. Longman, London.

Douthwaite, B., de Haan, N., Manyong, V.M., and Keatinge, J.D.H. 2003 Blending 'hard' and 'soft' science: The 'follow the technology' approach to catalyzing and evaluating technology change. In: Campbell, B.M. and Sayer, J.A. (eds.) Integrated natural resource management: Linking productivity, the environment and development. CABI Publishing, London.

Grant, P.M. 1976 Peasant farming on infertile sands. Rhodesia Science News, 10: 252-254.

Hagmann, J., Chuma, E., Murwira, K., Connolly, M. and Ficarelli, P.P. 2003

Success factors in integrated natural resource management R\&D: Lessons from practice. In: Campbell, B.M. and Sayer, J.A. (eds.) Integrated natural resource management: Linking productivity, the environment and development. CABI Publishing, London.

Hardin, G. 1968 The tragedy of the commons. Science, 162: 1243-1248. Kay, G. 1975 Population pressure and development prospects in Rhodesia.

Rhodesia Science News, 9: 7-13. 
Mandondo, A. 1997 Trees and spaces as emotion and norm-laden components of local ecosystems in Nyamaropa communal land, Nyanga District, Zimbabwe. Agriculture and Human Values 14: 353-372.

Mandondo, A. 2001 Allocation of governmental authority in tiered governance systems: The case of the Chivi Rural District Council landuse planning and conservation by-laws. African Studies Quarterly, 5(3). http://web.africa.ufl.edu/asq/v5/v5i3a3.htm.

PTA Consulting Services 1982 Study of the agricultural/rural development of communal areas of Mashonaland East Province, volume 4, District profiles. Report to the Ministry of Lands, Resettlement and Rural Development. Government of Zimbabwe, Harare.

Reason, P. 1999 Integrating action and reflection through co-operative inquiry. Management Learning special issue: The action dimension in management: diverse approaches to research, teaching and development 30(2): 207-227.

Reason, P. and Bradbury, H. 2003 Handbook of action research: Participative inquiry and practice. Sage, London.

Reason, P. and Heron, J. 1995 Co-operative inquiry. In: R. Harre, J. Smith and van Langenhove, L. (eds.) Rethinking methods in psychology. London, Sage.

Reason, P. and Torbet, W.R. 2001 The action turn: Toward a transformational science: A further look at the scientific merits of action research. Concepts and Transformations 6(1): 1-37.

Sayer, J.A. and Campbell, B.M. 2003 Research to integrate productivity enhancement, environmental protection, and human development. In: Campbell, B.M. and Sayer, J.A. (eds.) Integrated natural resource management: Linking productivity, the environment and development. CABI Publishing, London.

Sayer, J.A. and Campbell, B. (no date) Future harvests: Science to feed the world and save the environment. Future Harvest.

Wilson, K.B. 1989 Trees in fields in southern Zimbabwe. Journal of Southern African Studies 15: 369-383. 


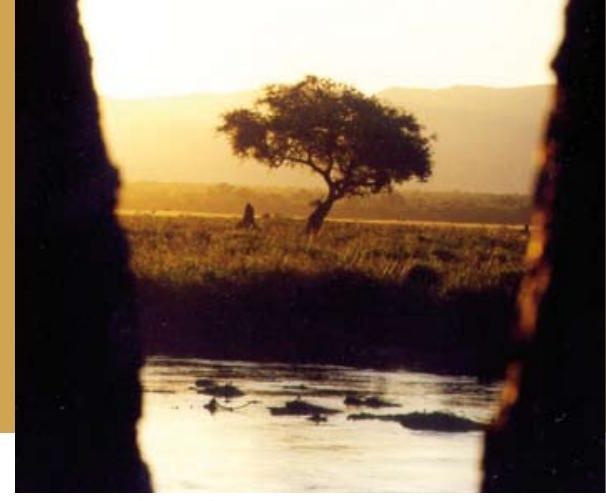

Sunset over the Zambesi River (Photo by Carol Colfer)

Chapter 5

A comparative analysis of adaptive natural resources management in Zimbabwe

Alois Mandondo

Frank Matose 
This discussion draws the preceding chapters together by considering

the body of experience emerging from the three case studies. The main issues raised in the introduction are here revisited as questions, classified into four distinct but related discussion domains. The first considers the extent to which each case was formally structured, since adaptive collaborative management (ACM) is an iterative 'learning whilst doing' process that occurs in a consciously structured way. The next section considers how nuances in each case's design impinged on outcomes, inasmuch as they are desired and expected. A subsequent section, informed by recognition that ACM is a 'patchy' process, considers both the undesired and the unexpected experiences emerging from the three cases. The last section then frames the outcomes within the context of the macroeconomic and political environment in the country and its unprecedented political and economic meltdown.

\section{Structure and process}

As argued in the introduction, practitioners facilitating ACM interventions largely seek to 'construct a deliberate link amongst plans, actions and outcomes' (Chapter 1). More elaborately stated, the approach involves 'incremental and experiential learning and decision making, buttressed by active monitoring of and feedback from the effects and outcomes of decisions' (Jiggins and Röling 1999). To what extent did the three cases construct and promote conscious and deliberate links amongst design, process and outcomes?

Though appearing to lack rigour in a few instances, the Mafungautsi case appears to have made a conscious effort to follow the classical participatory action research cycle of problem identification, planning for action, taking action and evaluating and replanning (Douthwaite et al. 2003; Lal et al. 2003). Before the intervention in Mafungautsi, participants underwent facilitated training for transformation to deal with passiveness, break the inertia and enhance familiarization among stakeholders engaging one another for the first time within an ACM encounter. The team wanted 
to identify areas in which local communities exhibited endogenous capacity to adapt and innovate on their own. The next stage involved problem identification, which was accomplished through visioning and scenario building, approaches in which participants built visions of the future as a first step towards redefining existing development pathways (see Wollenberg et al. 2000). This stage was crucial in ensuring that any resulting experimentation and learning were based on people's felt needs and priorities. The future scenarios considered only a limited range of minor forest products because the ACM project was restricted by the provisions of the resource-sharing arrangements. With people's visions having been ascertained, Mutimukuru et al. engaged the communities in planning for action. This was accomplished through a variety of platforms including community meetings, district-level workshops, look and learn visits and provincial agricultural shows. The action phase ${ }^{1}$ of the Mafungautsi project involved the formation of forest resource user groups, mostly constituted on the basis of extent of dependence on the resource base, as well as the nature and extent of resources occurring in each of the three study sites. The study's evaluation and replanning phase combined ad hoc discoveries with systematic collaborative monitoring and reflection.

The Chivi case, pursued in a communal area in semiarid settings in southcentral Zimbabwe, was less formally structured. The initiative appears as $a$ research project that subsumed a development agenda, with ACM approaches having been attempted happenstance on a component of the initiative that appeared designed to keep the development goals of the project in perspective. Adaptive learning approaches in this three-year integrated natural resources management project were factored in only during the second year, leaving little scope for formal monitoring and replanning.

In contrast, the Mawanga case, which was conducted in a communal area in north east Zimbabwe, was a development project that subsumed a research agenda. It therefore involved plenty of action and planning for action but inadequate follow-up and reflective work on how emerging findings could inform new cycles of adaptive action. Deforestation and perceptions of a widening gap between wood supply and wood demand provided an entry 
point for a development $\mathrm{NGO}$ to involve communities in identifying the underlying causes. Thus, problem identification was accomplished through participatory learning and action, which involved the use of 'problem trees' to identify both supply and demand side causes of deforestation. Planning for action resulted in a plan of supply and demand side actions to alleviate the problem, including conservation of existing woodlands through rotational use schemes and enforcement of tree harvesting bylaws, tree planting on plots and in the commons, and the introduction of fuel-efficient stoves. Meanwhile, the evaluation and replanning component of the Mawanga study mainly draws from an external evaluation done by Southern Alliance for Indigenous Resources (SAFIRE, an NGO).

Distinguishing the design features of ACM-based interventions is important because the approach is often unfairly evaluated on the basis of projects that are nominally of the same kind, but in fact bear few, if any, of its distinguishing features. We therefore, state explicitly that of the three cases covered in this study, only the Mafungautsi case bears broad resemblance to designs typifying formal ACM regimes, as outlined in the introductory chapter. This is not least because it consciously balanced action and reflection in identifying problems and reaching solutions to natural resources management. In contrast, both the Chivi and the Mawanga cases exhibit a lot of mostly ad hoc action, without commensurate formal and structured reflection. Such balance is essential in adaptive management. As Reason and Heron (2001 p. 179), point out, 'action research is concerned with re-visioning our understanding of our world, as well as transforming practice within it'. They coin the following aphorism as a guide to those striving to strike a balance between action and reflection: 'Too much reflection is armchair theorizing, and too much action is mere activism'. On the whole, though, it seems clear that processes of 'social learning' lead to improvement in management systems, and collaborative monitoring appears to play a useful role in supporting more structured learning. We next consider how differences in the design of the cases could have affected the nature of their outcomes. 


\section{Desired and expected outcomes}

The virtues of the ACM approach are said to be reducing fragmentation of knowledge, reducing likelihood of false and misleading conclusions, reducing possibility of conflict, improving information flows, realising transformative empowerment, promoting self-reliance, retaining institutional memory, achieving desired outcomes, achieving better and more equitable livelihood benefits, ensuring sustainable natural resource management, and so on. To what extent did the case studies accomplish these objectives?

This is not an easy question, in part because the short duration of the projects vis-à-vis the long term nature of the ACM approach, combined with differences in the projects' design and implementation, reduces the scope for definitive analysis. Evidence gleaned from all the case studies nevertheless suggests that considerable headway was achieved in attaining the informational, transformational and material aspects of the above objectives, particularly in the Mafungautsi study, where ACM interventions were more formally structured. For instance, Mutimukuru et al. observe that relationships between communities and foresters were strained at the beginning of the project. The first ACM activity - the report-back sessions after the context study - helped clear suspicions and misconceptions, thus bridging the gap between the two parties. Whereas foresters had suspected that communities were stealing precious timber from the forest, they were to learn that most tree stumps in the forest originated from previous logging by a timber concessionaire. And whereas communities saw the harsh face of the law in the foresters who accompanied the ACM team when it first arrived to engage with them, they were eventually to see the foresters as potential partners. An amicable and mutually supportive relationship had already been crafted by the time the project was fully underway, with both parties identifying problems and solving them together.

Besides achieving vertical integration, sharing and consolidating fragmented information at the local level also helped achieve horizontal integration, encompassing wider circles of people who could see better ways of doing 
things. This is amply illustrated by Mutimukuru et al. through the case of the knowledgeable beekeeper, who gave other community members detailed advice on better honey extraction practices. Nemarundwe and Mutamba describe how joint reflection forums provided the platform for the diffusion of information from individuals or small groups to wider circles of resource users in the Romwe site in Chivi. This was accomplished though a social experiment involving the distribution of seedlings of indigenous tree species to individual growers for independent experimentation. The experiments yielded a rich body of knowledge on site matching, germination patterns and growth rates of a variety of trees, subsequently shared with others in joint learning sessions. Similar objectives were achieved in the Mawanga case in Mutoko, albeit through the much different entry point of experimenting with designs of stoves intended to conserve energy, thereby reducing demand for biomass fuels.

The sharing of information can integrate people on a number of levels; in some instances it can even help overcome barriers that prevent larger groups of people from benefiting from forest-based activities. For instance, Mutimukuru et al. provide an example of a woman who made a lone foray into distant urban markets to sell her brooms, which secured her far bigger margins than she could have realised at the local district market. This generated interest amongst the other women, which helped ease the cultural barrier that prevents women from undertaking unchaperoned trips for business.

The transformational objective of ACM envisages a 'renaissance' mindset in which people are transformed from apathy to innovativeness, from despondency to hope, from recipients of solutions to authors of solutions, from inertia to initiative, and so on. The transforming effects of interventions pursued in the three case studies manifested in many ways. Three examples: women hitherto considered reserved and shy were empowered to take the lead in facilitating group meetings (Chapter 2); an ever-increasing number of women began participating in resource user groups (Chapter 2 ); men and women effectively articulated their customary rights to land and resources in front of state officials (Chapter 3). In some instances, 
the transformation went beyond the bounds of issues or actors initially considered in the ACM interventions to other spheres of life. For instance, Mutimukuru et al. provide evidence in which an empowered community in Gokwe engaged their local member of parliament, demanding better services. In other instances, people demonstrated maturity in balancing environmental and livelihood needs. For example, broom grass harvesters in Mafungautsi decided to cut the grasses instead of uprooting them, thus maintaining biological production, albeit at the expense of higher profits obtainable from uprooted brooms. The same groups were then able to increase the value of their cut grass brooms through decoration and more aggressive marketing.

There was also ample evidence across the three studies that gains achieved through ACM interventions were reversed when the researchers withdrew, particularly for Chivi. This lack of continuity may reflect other constraints as much as it reflects incomplete internalization of the transformation. Nevertheless, there are instances in which institutions that evolved within the ACM processes retained transformative energy even without facilitation. For instance, Chahweta and Mandondo describe how villages in the Ndemera area of Mutoko weaned themselves from facilitation and independently devised resource use regimes that applied not only to themselves, but also to people in other villages. Mutimukuru et al. describe how the death of the community's state forestry partner stalled ACM activities in two sites but not the third, where resource users continued to meet and decided to use money from their forest resources to build a house for schoolteachers. Evidence is, however, less than adequate to explain why some ACM institutions but not others can outlive the support offered by facilitation projects. There is, therefore, a need for future studies, ideally of a multi-variate nature, to distinguish ACM institutions or interventions by their degree of longevity. This also points to the need for much longer periods of engagement in ACM interventions than project-based approaches usually offer.

The material benefits of ACM across the three case studies are the most difficult to analyze and compare, mainly because either baseline studies 
or ex post studies (or both) could not be completed. Livelihood and environmental benefits arising from ACM-related interventions thus tend to be reported in anecdotal form, ranging from accounts of improved vegetation condition in the rotational grass and wood harvesting schemes in Mafungautsi and Mawanga, respectively, to the more resonant assertions that livelihoods improved. There is, therefore, need for more rigorous ex ante and ex post tracking of the material impacts of ACM interventions, if the whole approach is to verify its claims.

\section{Unexpected and undesired outcomes}

On face value, impressions of 'neatness' and 'order' in ACM are not entirely surprising, given that the approach is highly structured in conceptual terms. In practice, such 'neatness' and 'smoothness' often fragments into phases of disorder. All three case studies experienced these 'bumps in the road', as Prabhu and Matose term them in Chapter 1. What bumps were experienced along the road towards adaptive natural resource management in each of the three cases?

By and large, each ACM intervention involved only small groups of people sharing keen interest in the issues considered, and never the entire community. This gives the interventions a fragmented character. Additionally, ACM often entails the rearrangement of the hierarchy of actors and relations among them, which creates a new set of dynamics, often unexpected. For instance, the prominence given to previously littlerecognised women in Mafungautsi generated resentment and alienation among those formerly considered powerful, mostly men. The Chivi case, meanwhile, exhibits a different set of dynamics, in which researchers played a cat and mouse game with a local clan that exercised tight control over the flow of benefits, recognition and allegiance. The researchers eventually disentangled and diffused these elites' dominance but in the process earned the enduring resentment and malice of the clan. In many 
more instances than one, the vile anger of this new set of 'victims' bit back into ACM arenas with a vengeance. In a different but still unexpected way, engagement in ACM interventions gave some Mafungautsi participants the political savvy to pursue broader changes through participation in oppositional politics. This development was unheard of and constituted near sacrilege in this rural backwater in which allegiance was deemed due to $\mathrm{ZANU}-\mathrm{PF}^{2}$, the then ruling party. The political friction and uneasiness caused by this development sparked violence targeted against the resident facilitator; the ACM team's partner on the ground. The lesson from all these instances is that the impacts and outcomes of ACM do not remain quarantined within the natural resources management settings in which they are initiated, but permeate other spheres of people's lives.

The death of the state forestry partner also unleashed a new set of dynamics in which certain resource user groups slid back into dormancy, in part because they may have been overly dependent on the officer's energy and oversight. Others forged ahead but the conduct of their resource use and management business was significantly curtailed by the new officer, who was fixed in past ways of doing things, including restricting most forms of use of the forest by the communities. It could be argued that the dormant groups were prudent, given the problematic return to the old ways.

\section{Policy linkages}

In what ways did ACM interventions and broader policy processes impinge on each other? Evidence from the three case studies demonstrates that ACM interventions do not operate in social and political vacuums. If anything, the studies show that all ACM experiences bear the deep imprint of wider social, economic and political processes. For instance, although the Mafungautsi team decided to avoid any links between their interventions and the highly charged land issue, invasions of 'new settlers', encouraged by the state, continued to enter the Mafungautsi State Forest area and kept the issue alive. Though outside the law, these settlements received political endorsement from the legislator of the area, much to 
the dismay of the forestry officer, whose statutory duty it was to prevent settlement on state forest land. Mutimukuru et al. portray these settlers as adept political schemers who, instead of showing open hostility to the ACM team, sought to forge a mutual partnership in which the team would extend ACM to the invaded territory, thus legitimizing their claim.

By 2002, the land issue had merged into the political frenzy associated with the presidential election in that year, which saw vast swaths of rural land, including Mafungautsi, cordoned off because of political violence. This forced the facilitator team to stay at a safe distance. Team assistants and friends perceived to be in the opposition movement were branded 'enemies of the state', which forced them to leave in search of safer refuges, mostly in urban areas. Despite the lull in the two years preceding the harmonized elections of 29 March 2008, violence recurred. This time the rural countryside was closed off from contact with urbanites and the international humanitarian and development agencies in the name of reversing the 'regime change agenda'. Leading up to the presidential runoff set for 27 June 2008, the countryside was characterized by an unprecedented orgy of violence as ZANU-PF militias and war veterans tried to garner support for the incumbent. Meanwhile, almost all of the team's core facilitators were in the Diaspora, having fled the political and economic meltdown. The fate of the ACM institutions is currently unknown, but most likely they have simply withered away in the anarchy and violence.

The Chivi case was no exception either, as noted by Nemarundwe and Mutamba in Chapter 3. Political reprisals carried out in this district in response to the significant gains made by the opposition $\mathrm{MDC}^{3}$ party in the watershed 2000 elections saw the district's then administrator as well as the council's chief executive hounded out of office. The violent purges were executed by Liberation War veterans aligned with ZANU-PF, purportedly because these officials were perceived as biased in favour of the opposition party. The deposition of the district council's executive, as noted by Nemarundwe and Mutamba, disrupted many aspects of life, including implementation of the participatory and democratic vision 
of natural resource management the council had forged together with the communities. Meanwhile, as economic hardships bit deeper, most participants to the ACM interventions of the Chivi site drifted from subsistence and natural resource based-livelihoods to petty trading and wage employment, mostly involving illegal migration into South Africa. Migration not only changes the communities in terms of human numbers but also reduces the critical mass required to sustain the continuity people had become used to in various spheres of their lives, including natural resources management. Gold panning became another popular adjunct. Similar changes likely befell the Mutoko case.

Against this backdrop the HIV/AIDS pandemic has also been taking its toll. For a country with a prevalence rate that had stood close to 36 percent in 1996, funerals were not uncommon among people involved in ACM interventions in Chivi, as reported by Nemarundwe and Mutamba in Chapter 3. The statistics presented by these authors are chilling: 'In the three villages centred on the Romwe catchment, 24 percent of the households of the villages had lost a member in the last $4 \frac{1}{2}$ years. This is an average of 13 deaths per 1,000 persons per year, 37 percent above the national average at the time of the last census (1992)'.

Despite this rather lengthy treatment of the effects of wider political and economic developments on local communities, and in particular on ACM processes then underway in the sites, the local interventions had, in turn, effects on higher levels. For instance, as indicated earlier, individuals empowered through ACM interventions started agitating for more rights, entitlements and services, beyond management of natural resources. Quite often, the demands that such people made appeared to mirror problems at higher scales, as in Mafungautsi, where the demands included broadening the space for freer political participation. But citizens expressing a desire to be free invariably get officially viewed as 'regime change' agents, or worse still, 'puppets' of the West 'selling sovereignty' to imperial and capitalist merchants. This threadbare brand of patriotism is championed from within a 'great enclosure' ${ }^{4}$ of elite political interests whose crumbling walls bear a banner still boldly proclaiming: 'Zimbabwe Will Never Be a 
Colony Again'. ${ }^{5}$ It may well never be. But the tragedy is that most of the country's wretched citizens are distressed beyond the point where they can adapt to cope with the magnitude and vertiginous ${ }^{6}$ pace of decline in this man-made disaster.

\section{Epilogue}

Clearly, without adequate policy space to evolve, adaptive management approaches that depend on empowering the participating actors could be stifled at birth. Each of the three case studies was allowed to experiment in such a space, before events at larger political scales interfered. And yet all three case studies reveal that granted a little space, sufficiently empowered actors will seek to make that space larger, provided they have a sense of ownership of the ACM processes. Ownership and empowerment appear to be flip sides of the same coin, with little evidence to show whether there is any natural sequence between them. Unfortunately, it is also not possible, based on the available evidence, to draw any conclusions on how much policy space is sufficient, other than to say that it depends on the context.

One thing does appear clear: predetermined technical solutions are unlikely to succeed if they are mere prescriptions, without room for adaptation. Presumably, in such cases it is not just the nature of the solution or the fact that it might have been developed outside the place where it will be applied that undermines its potential for success; rather, it is the fact that a prescriptive approach precludes two-way communication. Misinformation and misperceptions then find fertile ground and can ultimately undermine success, as the Mafungautsi case amply demonstrates. In many ways, ACM is simply about focusing more sharply and effectively on fundamental human processes of communication, observation, learning and collaboration, and accepting at the same time that failures and surprises are the bumps that will be found along any road. 


\section{Endnotes}

${ }^{1}$ Reason and Torbet (2001) also refer to this phase as the 'action turn' of transformational approaches to learning and doing.

${ }^{2}$ ZANU-PF stands for Zimbabwe African National Union-Patriotic Front.

${ }^{3}$ MDC stands for Movement for Democratic Change.

${ }^{4}$ The Great Enclosure is the biggest complex of the ancient Zimbabwe Ruins, a tourist site in south-central Zimbabwe, from which the country derives its name.

${ }^{5}$ We refer the reader to the following website for a 'blood and thunder' hate speech by Robert Mugabe in which he seeks to portray the opposition as puppets of the West: http://allafrica.com/stories/200805260972.html

${ }^{6}$ Whereas the Zimbabwe dollar, as reported by Mutimukuru et al., stood at about USD $1:$ ZWD 1,700 in June 2003, by June 2008 it had slid to USD 1 : ZWD 2,000,000,000. However, when the redomination of 1 August 2006, resulting in dropping of the last three zeroes is factored in, this effectively translates into USD 1: ZWD 2,000,000,000,000. This means that the Zimbabwe currency lost strength first by factors of thousands, and then millions to billions, and thus effectively trillions within this five-year period. 


\section{References}

Douthwaite, B., de Haan, N., Manyong, V.M. and Keatinge, J.D.H. 2003 Blending 'hard' and 'soft' science: The 'follow the technology' approach to catalyzing and evaluating technology change. In: Campbell, B.M. and Sayer, J.A. (eds.) Integrated natural resource management: Linking productivity, the environment and development. CABI Publishing and Center for International Forestry Research, Bogor.

Jiggins, J. and Röling, N. 1999 Adaptive management: Potential and limitations for ecological governance. International Journal of Agricultural Resource Governance and Ecology Introductory Lecture on Challenges for Adaptive Management.

Lal, P., Lim-Applegate, H. and Scoccimarro, M. 2003 The adaptive decision-making process as a tool for integrated natural resource management: focus, attitudes, and approach. In: Campbell, B.M. and Sayer, J.A. (eds.) Integrated natural resource management: Linking productivity, the environment and development. CABI Publishing and Center for International Forestry Research, Bogor.

Reason, P. and Heron, J. 2001 The practice of co-operative inquiry: Research with rather than on the people. In: Reason, P. and Bradbury, H. (eds.) Handbook of action research: Participative inquiry and practice. Sage, London.

Reason, P. and Torbet, W.R. 2001 The action turn: Toward a transformational science: A further look at the scientific merits of action research. Concepts and Transformations 6(1): 1-37.

Wollenberg, E., Edmunds, D. and Buck, L. 2000 Anticipating change: Scenarios as a tool for adaptive forest management. Center for International Forestry Research, Bogor. 


\section{Center for International Forestry Research (CIFOR)}

CIFOR is a leading international forestry research organisation established in 1993 in response to global concerns about the social, environmental, and economic consequences of forest loss and degradation. CIFOR advances human well-being, environmental conservation, and equity by conducting research to inform policies and practices that affect forests in developing countries. CIFOR is one of 15 centres within the Consultative Group on International Agricultural Research (CGIAR). CIFOR's headquarters are in Bogor, Indonesia. It also has offices in Asia, Africa and South America. CIFOR works in over 30 countries worldwide and has links with researchers in 50 international, regional and national organisations. 


\section{Reviews and praise for Coping Amidst Chaos:}

This book is about coping amidst chaos. The chaos comes from a mixture of travails that have faced Zimbabwe over the past decade, ranging from broad-based political turmoil at a revolutionary scale, to the daily reality of losing loved ones and opinion leaders to the impartiality of AIDS. Coping occurs naturally through adaptation and learning. The coping is analysed through a series of three careful long-term participatory research efforts intended to explore the limits of adaptive comanagement (ACM) methods in some of the most stressed natural resource systems in the country: forests, drylands, and over-exploited communal woodlands. These studies remind us that ACM is not necessarily a panacea for ensuring reasonable exploitation of the resource base, although ACM may well give us better odds than the top-down prescriptive alternatives. During turbulent periods, there is a tendency for more fresh ideas to be generated, but their survival times are often too short to have an impact because of constant system churning and insurmountable constraints. Some of the learning mechanisms within ACM provide a potential bridge between today's turbulent era and some calmer period in the future when the best ideas may take a firmer foothold.

—Jack Ruitenbeek, H.J. Ruitenbeek Resource Consulting Limited, author of'The Invisible Wand: Adaptive Co-management as an Emergent Strategy in Complex Bio-economic Systems.'

These compelling descriptions and thoughtful analyses of three adaptive comanagement (ACM) projects in Zimbabwe place the reader smack in the middle of the often painful realities of doing participatory work in the context of a plummeting economy and volatile politics. The authors vividly show us what it means to take complexity seriously, the "bumps in the road" ACM practitioners are likely to encounter, and the complicated relations between development and research. Published just in the nick of time, this book provides instructive reflections on adaptive co-management that will be essential to those working with small farmers around the world who are struggling with the uncertainties created by global climate change.

- Louise Fortmann, Professor of Natural Resource Sociology, Rudy Grah Chair in Forestry and Sustainable Development, University of California at Berkeley

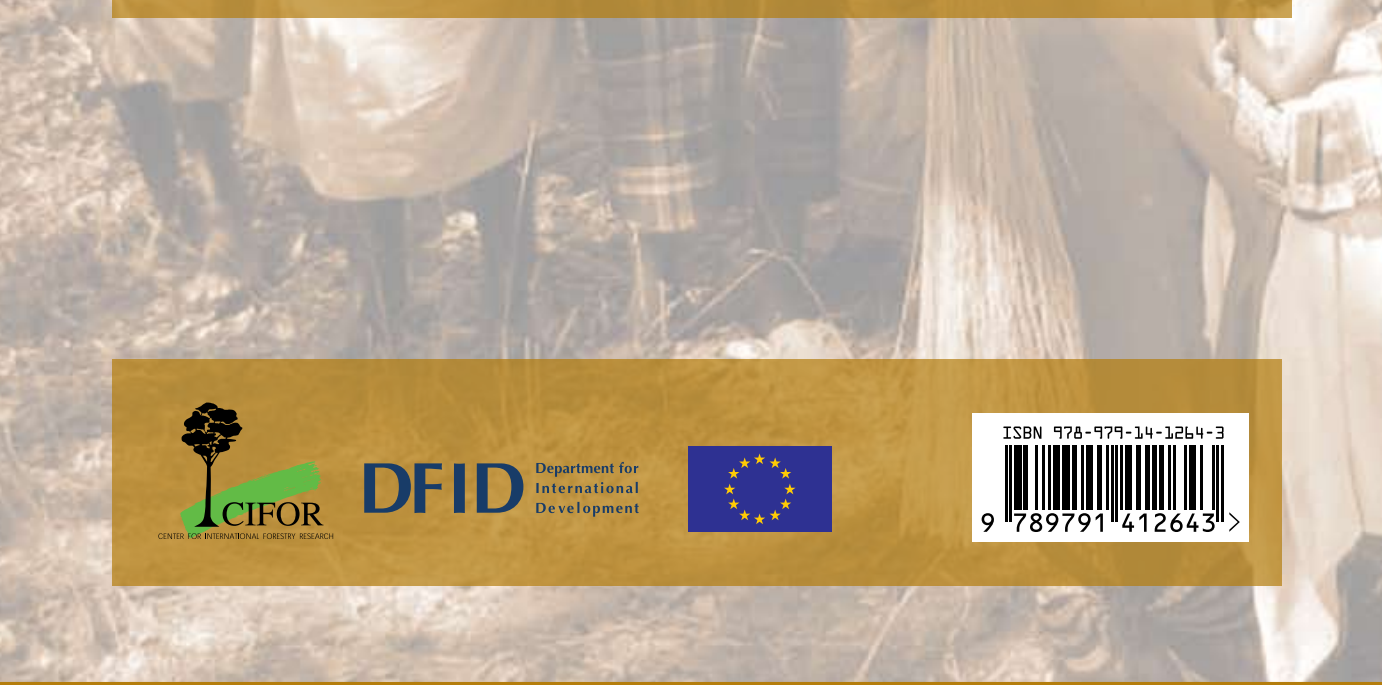

